\author{
Universidade de Brasília \\ Instituto de Ciências Humanas \\ Departamento de Filosofia \\ Programa de Pós-Graduação em Filosofia
}

\title{
EPISTEMOLOGIA MORAL: A ARGUMENTAÇÃO DE PUTNAM ACERCA DA OBJETIVIDADE DOS VALORES
}

Alexandre de Freitas de Mello Júnior

Brasília 
Universidade de Brasília

Instituto de Ciências Humanas

Departamento de Filosofia

Programa de Pós-Graduação em Filosofia

\section{EPISTEMOLOGIA MORAL: A ARGUMENTAÇÃO DE PUTNAM ACERCA DA OBJETIVIDADE DOS VALORES}

Dissertação apresentada ao Programa de Pós-Graduação em Filosofia da Universidade de Brasília, como requisito parcial à obtenção do título de Mestre em Filosofia.

Alexandre de Freitas de Mello Junior

Orientador: Prof. Dr. Erick Calheiros de Lima

Área de Concentração: Filosofia

Subárea de Concentração: Ética e Filosofia Política

Brasília 


\section{Agradecimentos}

Gostaria de agradecer à CAPES, pela bolsa de mestrado.

À minha esposa Maysa Massimo, sem a qual esse trabalho não existiria. Sua dedicação está impressa por todos os cantos dessa dissertação, por meio de sua leitura atenta e aconselhamento eficaz. Ela é a responsável pela renovação das minhas forças durante toda a laboriosa confecção desse texto.

Ao meu orientador professor Erick Lima, que abraçou esse projeto e se mostrou bastante interessado pelo tema, motivando-me sempre.

Ao professor membro da banca convidado Eros Moreira de Carvalho, por aceitar o convite, e por suas contribuições a este trabalho.

Ao professor Agnaldo Cuoco Portugal, por ter aceitado fazer parte da banca de qualificação, dando importante contribuição a este trabalho, e por estender essa contribuição como membro da banca de defesa.

Ao professor Herivelto Pereira de Souza, pelos importantes comentários feitos quando da qualificação desta dissertação.

Aos meus amigos Leandro e Aloísio, pelo constante interesse, empatia, reconhecimento e consolo.

Aos meus irmãos Gabriela e Lucas, pela proximidade.

Ao professor Ricardo Navia, da Universidad de la República, por generosamente ter me enviado do Uruguai um livro de sua autoria, além de responder minhas incômodas solicitações, e "por nossas inquietudes compartilhadas". 


\section{RESUMO}

A presente dissertação expõe o périplo percorrido por Putnam com o escopo de argumentar que a dicotomia fato/valor está fundamentada em noções errôneas dos conceitos nela envolvidos. A dicotomia, assim constituída, é o sustentáculo de um equívoco segundo o qual enunciados de valor, em especial enunciados éticos, não podem ser objetivos. Postulamos que enunciados éticos podem ser objetivos, mas para isso alguns conceitos centrais devem ser reformulados. Desse modo, é tematizado no primeiro capítulo o que são enunciados cognitivamente relevantes, na perspectiva do positivismo lógico, pois é a partir desse registro filosófico que Putnam reage às conclusões de que enunciados éticos não são objetivos. No segundo capítulo, analisa-se a noção de fato do positivismo lógico inspirada no empirismo britânico, apresentando uma rejeição dessa noção, quando considerada nesses termos. É lançada, também, uma crítica ao realismo da metafísica tradicional, fator esse fundante para o procedimento que Putnam irá realizar favoravelmente ao imbricamento entre as noções de 'fato' e 'valor'. 'Fato' e 'valor' estão intimamente relacionados, de tal forma que é impossível imaginar uma questão de fato que não contenha uma valoração qualquer e, a fim de demonstrar isso, abordamos a noção de 'conceitos éticos espessos'. No terceiro capítulo, é apresentada a primeira rodada do debate entre Putnam e Habermas, na qual a posição daquele está em evidência. Putnam faz considerações sobre a distinção habermasiana entre 'valor' e 'norma'. Habermas responde, e dá um panorama da filosofia de Putnam. Este realiza uma tréplica, esclarecendo pontos em que julga que Habermas enganou-se. No quarto e último capítulo, procuramos, por fim, explicar o que é o realismo pragmatista de Putnam, conhecido por realismo interno, dando uma fundamentação teórica a noção de objetividade que é condição necessária para se estabelecer a relevância cognitiva dos enunciados éticos. Para falarmos do realismo pragmatista, invocamos a 'relatividade conceitual' e o 'esquema conceitual', haja vista serem fulcrais para o seu entendimento.

Palavras-chave: Dicotomia fato/valor; objetividade; metafísica; realismo moral; conceitos éticos espessos; realismo interno; realidade conceitual; 


\begin{abstract}
This dissertation presents the journey traveled by Putnam with the scope to argue that the fact/ value dichotomy is based on misconceptions of the concepts involved. The dichotomy, thus constituted, is the basis of a misconception according to which statements of value, particularly ethical statements, cannot be objective. We postulate that ethical statements can be objective, but for that, some core concepts must be reformulated. Thus, the first chapter presents what cognitively relevant statements are, from the perspective of logical positivism, as it is from this philosophical record that Putnam reacts to the conclusions that ethical statements are not objective. The second chapter examines the logical positivism's notion of fact, actually inspired by British empiricism, to present a rejection of this notion, when considered in these terms. It also launched a critique of the realism of traditional metaphysics, which is a foundational factor for Putnam's procedure favorably to the entanglement between the notions of 'fact' and 'value'. 'Fact' and 'value' are closely related, so it is impossible to imagine a matter of fact that does not contain a valuation and, in order to demonstrate this, we discuss the notion of 'thick ethical concepts'. In the third chapter, the first round of debates between Putnam and Habermas is presented, in which Putnam's position is in focus. Putnam makes consideration of Habermas' distinction between 'value' and 'norm'. Habermas responds, and gives an overview of Putnam's philosophy. Then, Putnam performs a rejoinder to clarify points in which he believes Habermas was mistaken. In the fourth and final chapter, we finally try to explain what Putnam's pragmatic realism is, also known as internal realism, by giving a theoretical basis for the notion of objectivity, necessary condition to establish the cognitive relevance of ethical statements. In order to talk about pragmatic realism, we call down the 'conceptual relativity' and the 'conceptual scheme', considering they are central for it to be understood.
\end{abstract}

Keywords: fact/value dichotomy; objectivity; metaphysics; moral realism; thick ethical concepts; internal realism; conceptual reality 


\section{SUMÁRIO}

Agradecimentos $\quad$ iii

Resumo iv

Abstract $\quad \mathrm{V}$

INTRODUÇÃO 1

CAPÍTULO I: SOBRE O POSITIVISMO LÓGICO 5

1.1 Breve Contexto Histórico 5

1.2 A Crítica à Metafísica: a Proposta de Eliminação

$\begin{array}{ll}1.3 \text { O Princípio de Verificação } & 10\end{array}$

1.3.1 O "Sentido" na Acepção do Positivismo Lógico 14

1.4 As Proposições Sintéticas e as Proposições Analíticas 15

1.5 O Fisicalismo e a Modificação do Princípio de Verificação 18

1.6 As Consequências Éticas do Positivismo Lógico 21

CAPÍTULO II: DO NÃO COGNITIVISMO AO COGNITIVISMO DOS ENUNCIADOS ÉTICOS - A MUDANÇA NAS NOÇÕES DE FATO E DE OBJETIVIDADE

2.1 O Pano de Fundo do Empirismo Clássico 24

2.1.1 A Critica de Putnam à Noção de Fato do Positivismo Lógico 30

2.2 A Dicotomia entre Juízos de Fato e Juízos de Valor 34

2.2.1 Conceitos Éticos Espessos $\quad 45$

CAPÍTULO III: A APRESENTAÇÃO DA POSIÇÃO DE PUTNAM POR 48 MEIO DO DEBATE

3.1 Acerca do debate entre Hilary Putnam e Jürgen Habermas 48

3.1.1 O que há de comum nas posições distintas do debate? 49

3.2 A Dicotomia "Normas/Valores" e as Palavras Eticamente Espessas 55

3.2.1 Sobre a Teoria da Verdade Adotada por Apel 58

3.2.2 Naturalização e Relativização de Valores $\quad 62$

3.3 A Resposta de Jürgen Habermas a Putnam 65

3.3.1 Kant e Putnam $\quad 67$

3.3.2 Realismo pós-metafísico (realismo interno), segundo Habermas 68

$\begin{array}{ll}\text { 3.3.3 Objetividade e Naturalismo Mental } & 70\end{array}$

3.3.4 A Relativização a Partir do Contexto 72

3.3.5 O Conceito de Razão Pragmatista $\quad 74$

3.3.6 A Colocação do Problema Acerca da Objetividade dos Valores 75 
3.3.7 As Três Considerações em Favor da Validade dos Juízos 77 Valorativos

3.4.1 A Explicação de Putnam sobre sua Posição $\quad 80$

CAPÍTULO IV: REALISMO INTERNO E RELATIVIDADE CONCEITUAL 87 CONCLUSÃO 94

BIBLIOGRAFIA 99 


\section{INTRODUÇÃO}

A presente dissertação de mestrado, requisito parcial à conclusão do mestrado acadêmico de Filosofia, tem como objetivo apresentar a posição de Putnam acerca da objetividade dos valores morais. Putnam tem sido um filósofo importante no que concerne à discussão sobre a ética, aliando a crítica da dicotomia fato/valor às críticas ao realismo tradicional e ao positivismo lógico. Embora Putnam seja um filósofo mundialmente reconhecido, suas posições sobre o tema da objetividade dos valores morais não têm ganhado a devida atenção. Destarte, o autor deste trabalho procura apresentar o périplo da argumentação putnamiana sobre esse tópico, inclusive utilizando, para essa finalidade, um debate entre Putnam e Habermas, este último bastante conhecido do público brasileiro.

Por que Putnam se interessa por essa discussão acerca da objetividade dos valores éticos? Putnam está às voltas com o tema da objetividade dos valores éticos motivado por John Dewey ${ }^{1}$, filósofo pragmatista norte americano; e por uma crítica ao realismo da metafísica tradicional e suas várias decorrências, sendo que a mais combatida por ele é o relativismo cultural. Dewey motiva Putnam por meio de sua crítica ao pensamento atual, criador de dicotomias, como por exemplo, "pensamento/ação", "ideal/real", “espírito/natureza". Putnam se inspira em Dewey para iniciar sua própria crítica à dicotomia fato/valor. Embora Putnam não tenha sido o primeiro a perceber essa dicotomia, é ele quem vai relacioná-la, simultaneamente, a uma crítica ao realismo tradicional e ao positivismo lógico, herdeiro do empirismo clássico.

É com o abandono de Putnam ao ideário positivista, desde a publicação de Razão, Verdade e História, de 1981, que ele enceta uma crítica à noção tradicional de fato que repercute na reconfiguração do conceito de objetividade. É também nessa obra que pela primeira vez ele irá se referir à dicotomia fato/valor e relacionar a consolidação dessa aos pressupostos do positivismo lógico.

Putnam irá desenvolver, nessa obra de 1981, o que se tem chamado de "realismo interno", cujo projeto é iniciar uma alternativa ao realismo da metafísica tradicional. É essa criação conceitual que vai dar origem à sua virada pragmática, caracterizada, sobretudo, pelo incômodo causado pelos pressupostos tradicionais da filosofia. Ademais, a iniciativa de oferecer um realismo apartado das incumbências tradicionais nasce do também incômodo

\footnotetext{
${ }^{1}$ Algumas obras em que Dewey alude ao assunto são Reconstrução Em Filosofia; A valoração das ciências humanas; e Teoria da Vida Moral, todas arroladas na bibliografia deste trabalho.
} 
gerado pelo relativismo cultural que é resultado de algumas versões alternativas que também têm sido apresentadas nos últimos anos ${ }^{2}$.

O itinerário do presente trabalho será o seguinte: no primeiro capítulo apresentaremos as principais linhas do positivismo lógico. Inicialmente, faremos uma contextualização histórica, mostrando como o positivismo lógico se reúne em Viena em torno de figuras muito importantes, como Moritz Schlick e Rudolf Carnap; posteriormente, apresentaremos a proposta do positivismo lógico de eliminar a metafísica; ainda, desenvolveremos a noção do princípio de verificação, central ao registro filosófico em questão. Explicaremos, por ocasião do tema do princípio de verificação, a noção de "sentido"; terá azo, por fim, a clássica distinção entre proposições sintéticas e proposições analíticas.

Abordaremos brevemente o fisicalismo, a mudança sensível no princípio de verificação, e as consequências das posições do positivismo lógico para a ética, destacando-se que, segundo essa tradição, os juízos éticos não têm uma dimensão cognitiva. Iremos expor as bases dos argumentos que levam os positivistas lógicos a endossar esse tipo de afirmação, e, para tanto, será conveniente descrever os pressupostos do positivismo lógico e suas convicções, culminando com uma discussão de qual seria a sua proposta para o caso da ética.

No segundo capítulo, Putnam lança uma crítica ao positivismo lógico, reconhecendo sua base empirista para noções que lhe são fundamentais. Desse modo, revela a herança do empirismo clássico, notadamente o humeano, e critica sua noção de fato. A estratégia de Putnam é indicar que a dicotomia entre os enunciados de fato e os enunciados de valor repousa em considerações equivocadas, coisa já evidente desde a formulação da dicotomia analítico/sintético, de onde parte para explicar o colapso da dicotomia fato/valor. Depois de a crítica ao positivismo lógico ser lançada, Putnam critica o realismo tradicional para solapar a noção clássica de fato. Após isso, ele pode procurar assegurar certa objetividade aos valores éticos, a partir do que é demonstrado por meio das considerações acerca dos conceitos éticos espessos.

No terceiro capítulo será exposto o debate Putnam-Habermas acerca da questão da cognitividade dos enunciados normativos. A razão de o debate ser exposto no fim deste trabalho atende à nossa preocupação de demonstrar o quão premente e intrincada é a questão sobre a objetividade dos valores. Há uma introdução ao debate que procura fazer com que as questões comuns à posição pragmatista, que ambos dividem como pano de fundo, se tornem

\footnotetext{
${ }^{2}$ Um exemplo disso pode ser visto no livro Filosofia e o Espelho da Natureza (1979), de Richard Rorty (1931-2007), que oferece um relativismo generalizado como decorrência da recusa da metafísica tradicional.
} 
claras, e que, a partir desse ambiente comum, algumas diferenças possam ser pontuadas de tal forma que a reflexão de Putnam esteja, ao final, mais nítida.

Quando do debate, poderemos perceber que algumas questões adicionais são levantadas, e avaliaremos a relevância de respondê-las imediatamente ou apontar caminhos para uma resposta consistente e pormenorizada no futuro. A postura crítica de Putnam o faz ressaltar certos pressupostos rejeitados por si, ao mesmo tempo em que levanta pontos por ele preconizados. A isto se segue uma réplica de Habermas que, muito longe de tentar corrigir a interpretação crítica que é feita por Putnam à sua obra, objetiva aclarar certas teses putnamianas.

O debate ganha, dessa forma, um delineamento de apreciação das posições de Putnam sobre o tema, uma vez que o próprio Habermas se posiciona como seu interlocutor. Posteriormente a essas considerações, Putnam lança uma tréplica que irá auxiliar a nortear o aprofundamento de suas teses específicas. O debate, portanto, é importante, na medida em que apresenta esclarecimentos e possíveis desdobramentos do posicionamento de Putnam.

Sob essa perspectiva, o debate será dividido em três partes, a saber: 1) uma crítica de Putnam a Habermas no que respeita à dicotomia normas e valores; 2) uma resposta de Habermas a Putnam, sem dirigir-se diretamente à crítica que Putnam alinhava na primeira parte. Sua resposta, na verdade, busca caracterizar a posição putnamiana; 3) considerações de Putnam à resposta de Habermas expondo, desta forma, um tipo peculiar de argumentação.

No parte 1 do terceiro capítulo, Putnam esforça-se para deslindar o embrião de sua postura com relação à objetividade dos valores, e para isso adentra ao debate da dicotomia entre normas e valores. Nesta parte, Putnam obtempera, reiterando-se aqui o já trabalhado no segundo capítulo, que uma distinção estanque entre normas e valores é falha. A apresentação do seu argumento nos conduz, igualmente, à teoria dos conceitos éticos espessos, segundo a qual certos valores estão carregados intrinsecamente de ações e avaliações que não podem ser desvencilhadas de seu aspecto meramente semântico. Em seguida, critica a teoria da verdade inspirada no pragmatismo, e para fazê-lo, Putnam traz à baila Apel e Peirce, e faz reservas a ambos. Putnam conclui ser impossível uma noção de norma que não esteja repleta de conteúdo, ou seja, que tenha um caráter meramente formal. Desse modo, enunciados normativos não podem ser totalmente separados dos valores.

$\mathrm{Na}$ parte 2, Habermas procura explanar passo a passo a posição de Putnam, caracterizando-a como um pragmatismo kantiano. Para isso, sua estratégia é caracterizar o 
ponto de vista epistemológico de Putnam, que, segundo Habermas, é um kantismo destrancendentalizado. Na sequência, passa a uma conceituação do realismo metafísico com relação à moral que supõe que Putnam adere. Esse realismo, chamado por Habermas de pósmetafísico, é o realismo interno.

Depois, Habermas mostra como Putnam rejeita a naturalização da razão, aspecto que prenuncia a reformulação da noção tradicional da objetividade. Em seguida, Habermas explica como Putnam rejeita o relativismo baseado no contexto, apresentando um interessante argumento contra a teoria da incomensurabilidade kuhniana. Com isso, o conceito de razão pragmatista é apresentado em uma acepção epistemológica, ao que depois Habermas coloca o problema atinente à objetividade dos valores, tal como pensa fazer Putnam. A análise culmina em uma abordagem acerca da validade dos enunciados de valor, ou juízos valorativos.

Na parte 3, Putnam responde a Habermas, e é possível perceber certas posturas que já estarão postas no segundo capítulo, de modo a fornecer uma elucidação crucial à sequência deste trabalho. Putnam, em desacordo com aquilo que Habermas pensa ser seu posicionamento, rejeita a posição que esse lhe atribui, a saber, de que: a) todos os enunciados empíricos possuem um tipo de validade unívoco; b) 'Verdadeiro' é o nome pelo qual chamamos este tipo de validade; c) todos os enunciados éticos corretos são igualmente válidos, ou seja, têm um tipo de validade unívoco.

Posteriormente ao debate, concluiremos o delineamento das posições de Putnam no que tange à questão da objetividade dos valores, expondo, no quarto capítulo, o que é o realismo interno, compreendido como um realismo pragmatista (PUTNAM, 1994, 61), e desenvolvendo, consequentemente, o que significa relatividade conceitual e esquema conceitual. É nessa conjuntura que Putnam pode falar de objetividade mesmo em um cenário que alija o realismo tradicional.

A partir do programa acima exposto, esperamos que este trabalho possa contribuir tanto para esclarecimentos concernentes à problematização da objetividade dos valores, quanto para a elucidação acerca dos seus pressupostos, tal como visualizado por Putnam. Igualmente, acreditamos que a linha seguida por Putnam é demasiadamente promissora para não ser devidamente conhecida no meio acadêmico filosófico brasileiro. Suas contribuições mais recentes, apesar de importantes e consistentes, não têm recebido o apreço que merecem, de modo que este trabalho também visa a dirimir este fato. 


\section{CAPÍTULO I: SOBRE O POSITIVISMO LÓGICO}

\subsection{Breve Contexto Histórico}

No início do século $\mathrm{XX}$, iniciou-se um movimento que planejou promover uma revolução no que até então fora visto no campo da filosofia. O nome pelo qual tal empreendimento filosófico ficou gravado na história é positivismo lógico, também chamado de "empirismo lógico" ou "neopositivismo". Embalado pelo forte estímulo que havia sido propiciado pela lógica de Friedrich Ludwig Gottlob Frege e pelo livro de autoria de Bertrand Russell e Alfred North Withehead, o famoso Principia Mathematica, Moritz Schlick, idealizador do positivismo lógico, reuniu em torno de si alguns dos nomes importantes da intelectualidade vienense, motivo pelo qual o Positivismo Lógico também é conhecido como Círculo de Viena. Entre eles encontravam-se filósofos, sociólogos, matemáticos e cientistas, destacando-se Otto Neurath, Rudolf Carnap e o próprio Moritz Schlick. A intenção inicial não foi a de instaurar de imediato um movimento filosófico. O grupo de intelectuais, a princípio, reunia-se com o objetivo de debater determinados temas de interesse filosófico e científico.

Porém, a partir de 1929, o Círculo de Viena tencionou comutar-se em um movimento de expressão mundial, e para tanto foram organizados diversos congressos, nos quais participaram massivamente filósofos e cientistas alemães, poloneses, norte-americanos, britânicos e escandinavos. Houve, nesse ano, a publicação de um manifesto do Círculo de Viena, intitulado A concepção científica do mundo, no qual são expostas as linha mestras do positivismo lógico. Por volta desse período, novos nomes de vulto foram agregados ao Círculo, podendo ser mencionados Richard von Mises, Carl Hempel e Hans Reinchenbach, esse último participando também ativamente como editor da revista Erkenntnis, que foi o principal veículo de distribuição e comunicação do ideário positivista.

Na década de 1930, o Círculo de Viena esteve no ápice de sua produção, embora fossem patentes as dificuldades que desembocariam no seu descalabro. Moritz Schlick, líder e idealizador do grupo, seria assassinado por um ex-aluno ligado ao partido nazista. O clima de incerteza, gerado pela periclitante situação da política alemã, teve como consequência provocar a dispersão dos membros do Círculo de Viena. Seu destino foram os Estados Unidos da América, país onde esses filósofos e cientistas renomados puderam encontrar o acolhimento em universidades de excelência e, assim, continuar suas reflexões. 
Nessa época, ainda, temos a consolidação do que será a versão clássica para a compreensão dos principais pontos do positivismo lógico, por meio da publicação, em solo inglês, da obra Language, Truth and Logic, de autoria de Alfred Jules Ayer. O deslocamento dos principais membros do Círculo de Viena para os Estados Unidos da América, e a publicação da obra de Ayer em terras britânicas, encetou uma influência cada vez mais crescente do positivismo em países anglófonos.

Os principais pontos que podem ser arrolados como fundamentais para a perspectiva do positivismo lógico, e que serão tratados neste capítulo, são:

1. A rejeição da metafísica, historicamente estimulada de modo enfático pela tendência contra-idealista, ou seja, na reação aos pressupostos do idealismo alemão, principalmente os desenvolvimentos de cunho britânico, encetados por Francis Herbert Bradley $^{3}$, dentre outros.

2. O princípio de verificação, instaurado como a condição necessária para que o conhecimento ocorra de fato, ao mesmo tempo em que se dá o resgate das contribuições do empirismo britânico. A inclinação do positivismo lógico para delinear os limites do conhecimento, onde ele deve ser demarcado, possui uma forte e vivificadora inspiração cientificista. Essa inspiração é motivada pelos sucessos constatados pelo incremento no conhecimento científico do início do século XX. Entretanto, o conceito de verificação será, a uma só vez, um conceito fundamental e um dos que mais dificuldades irá gerar para o programa positivista, passando por sucessivas reconfigurações e desdobramentos.

3. Os juízos analíticos e sintéticos, que serão o conjunto de enunciados que preencherão todos os requisitos no tocante ao que se poderá chamar de sentido, em uma proposição. A partir do desenvolvimento da crítica à metafísica, e do princípio de verificação (que estão em (1) e (2)) poder-se-á constatar o que é o sentido de uma proposição, ou, dito em outras palavras, poder-se-á constatar o método de apreensão dos aspectos cognitivos desse conjunto de enunciados.

\footnotetext{
${ }^{3}$ Francis Herbert Bradley (1846-1924) foi o maior idealista inglês. Bradley rejeita o empirismo, na medida em que rejeita uma relação entre as experiências e os pensamentos. Segundo seu idealismo absoluto, a realidade é somente aquilo que possui unidade e totalidade. Tudo o mais é uma versão fragmentária e parcial do real, incluindo-se nisso o pensamento. A linguagem só é capaz de formular parcialmente a verdade, e sua gramática é categorizada como inadequadas a propiciar o absoluto que explica a totalidade do real. Suas principais obras são Appearence and Reality (1893), Ethical Studies e (1876) Principles of Logic (1883).
} 
Desse modo, poderemos adentrar na perspectiva instaurada pelo positivismo lógico por meio de sua crítica à metafísica, que grassava na ocasião histórica na qual ele se situa para, em seguida, apresentar o que há de mais central na caracterização do projeto positivista. A crítica produzida, e consequente ruptura, é a pedra angular sobre a qual irá ser erigido o empreendimento filosófico que o positivismo oferecerá como contraponto à situação filosófica presente até então. Assim, comecemos a análise do que vem a ser a crítica positivista à metafísica, proposta de modo radical como sua própria eliminação.

\subsection{A Crítica à Metafísica: a Proposta de Eliminação}

Para darmos início ao posicionamento do positivismo lógico com relação à metafísica, será importante, primeiro, caracterizar o que é metafísica. A partir da resposta à pergunta o que é metafísica, do modo como fora proposto pelo registro filosófico ora aqui tratado, poderemos explicar as razões trazidas para a solução radical almejada, qual seja, eliminar a metafísica de todo o discurso que pretende galgar o patamar excelente do conhecimento.

Como foi descrito por J. R. Weinberg (1959, p. 237), os positivistas lógicos destacam que um traço comum a todas as asserções de caráter metafísico é não serem empíricas. Isso significa que não pode haver um método empírico que funcionará de tal modo a vir a constatar as asserções metafísicas que, assim, carecem da possibilidade de ter instituídas a si próprias os valores de verdade ao conteúdo que pretendem exprimir.

A verdade da crítica do positivismo encontra lastro na defectibilidade que há em assegurar às considerações metafísicas uma fundamentação baseada na demonstração lógica e/ou em algum método de verificação estabelecido experimentalmente. Aqui se insinua o tratamento específico (e também propositivo, que é parte do mote programático do positivismo), uma vez que se começa a forjar o ambiente no qual as proposições poderão estar garantidas no que se refere ao seu sentido. A falta de possibilidade de uma demonstração lógica e de um meio que possa assegurar experimentalmente o sentido de uma frase esboçamse como dois critérios a serem desenvolvidos como necessários, ainda que não concomitantemente, para podermos falar claramente sobre verdade ou falsidade de uma asserção.

Seguindo, ainda, em busca da caracterização positivista da metafísica, podemos elencar outro apanágio, segundo o qual a proposição dos sistemas metafísicos é apresentada como esquemas aos quais a realidade deve ser acoplada, uma vez que esses sistemas são a 
descrição fiel de como funciona a estrutura invisível do mundo. Weinberg (1959, p. 238) descreve dois componentes principais dos sistemas: no primeiro, deve haver uma explicação consistente das experiências do mundo; no segundo, a convicção de que mesmo que não haja um fator que possa nos fazer conceber o sistema proposto como a priori, considera-se que ele é imprescindível como uma explicação teórica para a experiência.

Os postulados da metafísica podem ser propostos axiomaticamente e, desse modo, fornecerão corolários pela via da dedução lógica. Nesse caso, os axiomas não deverão ser estabelecidos simplesmente como crenças arbitrárias, mas, antes, como verdades evidentes. À maneira de truísmos, esses postulados precisarão ser claros. Adicionalmente, outro requisito se faz presente: as verdades obtidas por meio da dedução deverão respeitar os princípios lógicos, de modo a não gerarem nenhuma inconsistência. Aquilo que é o "possível”, e o que é o "contingente", mas não é o "necessário", deve ser completamente desconsiderado. Na metafísica dedutiva não há espaço para a experiência.

Outros modos de metafísica podem também ser formulados. Weinberg (1958, p. 239) nos ensina que podemos supor duas alternativas para essas espécies de sistemas de proposições metafísicas: na primeira, as asserções filosóficas são determinadas de modo empírico no tocante à sua verdade ou falsidade, ao que se considera que essas asserções são abstrações que podem ser reduzidas a enunciados das ciências naturais, coincidindo, finalmente, com esses; e na segunda, não há meio de estabelecer um modo experimental para constatar os conteúdos das asseverações metafísicas, ficando a verificação de tais enunciados restrita a uma forma não experiencial.

Portanto, não há uma maneira de asserção metafísica que seja passível de submissão a um método de verificação. É justamente essa característica da metafísica que será entendida como uma carência pelos positivistas. As asserções da metafísica não serem empíricas é uma falha que a coloca distante do conjunto de enunciados que se pode classificar como plenos de sentido.

Do mesmo modo que Weinberg enfatiza o aspecto não cognitivo de frases que não podem ser verificadas por um método, Alfred Jules Ayer coloca a questão do desarrazoado de sentido em termos do conhecimento que se pretende alcançar pela via metafísica, a saber, o conhecimento transcendente do mundo para, em seguida, realizar a mesma crítica que Weinberg acerca da não cognitividade dessa espécie de frases. Tal conhecimento possibilitaria um conhecimento superior do mundo, uma vez que ele se situa em um ponto inalcançável "pela ciência e pelos sentidos comuns” (AYER, 1971, p. 37). 
Segundo Ayer, para se começar a refutar a metafísica deve-se empreender um sistemático questionamento a respeito de quais premissas parte o metafísico para que encontre, por dedução, as proposições resultantes que formam a realidade transcendente ao mundo fenomênico. A afirmação de Ayer é que "sem dúvida, de premissas empíricas não se pode, legitimamente, inferir-se nada concernente às propriedades, nem sequer a existência de algo supra empírico" (1971, p. 38). Todavia, continua, estabelecer que, de uma premissa empírica não se segue uma conclusão transcendental, não é suficiente para refutar o metafísico, pois esse sempre poderá dizer que não é a partir da experiência que ele chega à constituição de uma realidade transcendental, mas, sim, a partir de alguma espécie de "faculdade de intuição intelectual"4.

Portanto, para resolver a questão e refutar a metafísica, a linha a ser perseguida por Ayer visa a procurar descortinar a natureza das declarações reais que por ela são propostas. Esse empreendimento tem como objetivo demonstrar que nenhuma proposta que transcenda a realidade sensorial pode ter significação cognitiva. Se esse for o caso, então fica demonstrado que a metafísica é sem sentido e, assim, deve-se erigir o conhecimento em outras bases. Para tanto, é preciso esclarecer que:

\begin{abstract}
....a esterilidade da pretensão de transcender os limites da possível experiência sensorial se deduzirá, não de uma hipótese psicológica relativa à constituição real da inteligência humana, mas da norma que determina a significação literal da linguagem. Nossa acusação contra o metafísico não se funda em que este pretenda utilizar o conhecimento em um campo em que não pode aventurar-se proveitosamente, mas em que produz frases que não logram ajustar-se às condições que uma frase tem de satisfazer, necessariamente, para ser literalmente significante (AYER, 1971, p. 39).
\end{abstract}

Os positivistas lógicos irão fazer nesse momento, à guisa de refutação da metafísica, a maior e mais controvertida proposta de seu projeto, a saber, o princípio de verificação. $\mathrm{O}$ argumento positivista, remontado por Ayer, pode ser formulado nos seguintes termos:

1. Uma realidade transcendente não pode ser deduzida do mundo empírico.

2. Se (1) é o caso, então nenhuma metafísica que se preocupe em formular uma realidade transcendente poderá fazê-lo a partir do mundo empírico.

3. Somente as asserções cujos conteúdos podem ser verificados deverão ser constitutivas de frases cognitivamente relevantes.

4. Somente asserções empíricas podem ser verificadas.

\footnotetext{
${ }^{4} \mathrm{O}$ que quer que seja a "faculdade de intuição intelectual” Ayer não explica. Podemos esclarecer minimamente o que pode significar o termo intuição por meio da explicação de Simon Blackburn, segundo a qual ela é a "consciência imediata tanto da verdade de uma dada proposição como de um objeto da apreensão, como, por exemplo, um conceito. Afirma-se que o conhecimento da passagem do tempo ou da natureza infalível de Deus também são intuições" (1997, p. 208).
} 
5. Portanto, uma metafísica que se preocupe em formular uma realidade transcendente não poderá constituir frases cognitivamente relevantes. (premissas $2,3,4)$

Se a metafísica não está apta a produzir um discurso cognitivamente relevante, ou seja, um discurso com sentido, isso quer dizer que não há razões que lhe assegurem um lugar privilegiado no universo filosófico, ou mesmo um lugar qualquer. Em assim sendo, não se haverá de levar em consideração qualquer tentativa metafísica de discorrer sobre o mundo, o que culmina em sua refutação. A questão é agora tentar mostrar o que é o método de verificação de uma frase, e com isso apresentar o princípio que, segundo Ayer, expõe a primazia da forma empirista de abordar a realidade.

Weinberg explica que a tendência anti-metafísica presente no positivismo lógico possui duas vertentes: a primeira, "a demonstração de que todas as proposições podem reduzir-se às proposições elementares que se verificam imediatamente na experiência"; e a segunda,“ a demonstração de que a metafísica é resultado dos erros de sintaxe lógica” (1958, p.239).

Passemos à análise da primeira vertente, e desse modo poderemos entender o teor da refutação à metafísica acima colocada. Na sequência da explicação ao princípio de verificação poderemos discorrer sobre o que os positivistas querem dizer com "sintaxe lógica".

\subsection{O Princípio de Verificação}

Segundo Ayer, "O critério que nós (positivistas) utilizamos para provar a autenticidade de aparentes declarações de fato é o critério de verificação" (1971, p.40). Porém, como está instituído, e configurado, esse critério? Ora, se descrevemos um critério de verificação, devemos estabelecer que coleção de objetos pode ser verificada. O esclarecimento concernente a isso é crucial. A tendência empirista do positivismo fixa como início do conhecimento, e sua consequente condição necessária, a apreensão sensorial da realidade. Pode ser conhecido somente aquilo que estiver em um âmbito capaz de ser capturado pelo nosso aparato sensório.

A possibilidade do conhecimento está diretamente relacionada com a possibilidade de se produzirem dados dos sentidos. Esses dados são a evidência que precisará passar por um 
escrutínio para que sejam determinados falsos ou verdadeiros. Procede-se a partir dos dados dos sentidos em direção à formulação de alegações com as quais se levantam pretensões de verdade; posteriormente, faz-se a tentativa de constatar o conteúdo das alegações. Não se poderia chegar a qualquer tipo de constatação se não se seguisse esse itinerário. $\mathrm{O}$ que pode fornecer material para uma espécie de convicção cabal é o que se tem de avaliar, ou seja, o objeto em questão apreendido pelos sentidos.

Aquilo que tem o condão de produzir a prova sobre o que se está a propor é uma conjuntura configurada pelo objeto a ser analisado: a possibilidade de o objeto em questão estar sob o alcance dos sentidos, e a formulação de uma alegação em torno do objeto em questão. Finalmente, utiliza-se um meio segundo o qual se está habilitado a concluir se as pretensões de verdade levantadas acerca da questão correspondem ou não correspondem ao objeto. Nesse sentido, Ayer afirma o abaixo exposto:

Dizemos que uma frase é factualmente significante para uma dada pessoa, sempre e quando essa pessoa conheça como verificar a proposição que a frase pretende expressar, e dizer se conhece que observações induziram, sob certas condições, a aceitar a proposição como verdadeira, ou rechaçá-la como falsa (1971, p. 40).

A tarefa de abrigar uma proposição sobre a chancela de 'verdadeira' ou 'falsa' está condicionada pela sua verificação. E 'verdadeiro' e 'falso' são mais do que signos que se referem à afirmação ou negação de um enunciado, de modo que verdade ou falsidade de uma frase está, destarte, reduzida a formas possíveis de confirmação das proposições, como sugere Ayer (1971, pp. 103-104). 'Verificar' é, desse modo, a condição genérica para apreciação devida de uma frase. Devemos nos restringir à observação dos dados dos sentidos para lograr êxito na tarefa, pois, como disse Schlick:

Se a rejeição da Metafísica por parte do Positivismo equivaler à negação da realidade transcendente, parece ser a conclusão mais natural do mundo que ele só reconhece realidade ao ser não transcendente. Assim, o princípio básico do Positivismo parece rezar: “somente o dado é real" (1988, p.41).

Parece ser o caso de que a rejeição da metafisica proposta pelo positivismo tem como objetivo refutar uma hipotética realidade transcendente, como foi visto na seção anterior. Portanto, se verificar é verificar a realidade, isso quer dizer que se deverá promover a verificação dos dados. Embora já tenhamos abordado a peculiaridade fundamental do positivismo lógico no tocante à necessidade da experiência, será válido citar outra afirmação daquele que foi seu ferrenho arauto e defensor: 
Ora, pela análise filosófica não logramos decidir se uma coisa é real, mas somente descobrir o que se quer dizer ao afirmar que a coisa é real. Se este é o caso ou não, só podemos descobri-lo através dos métodos habituais da vida diária e da ciência, pela experiência. (SCHLICK, 1988, p. 43)

Dito o supracitado, fica inequivocamente confirmado que os dados são dados advindos da experiência, e que por 'métodos habituais da vida diária' não se pode entender outra coisa senão 'aparato sensorial'. A constatação dos dados dos sentidos como sendo basilar assinala uma consequência aqui implícita, qual seja, a noção de questões de fato como o objeto da perscrutação positivista.

Não obstante, Ayer discorre sobre uma peculiaridade visível na verificabilidade, denominada por ele de "verificabilidade prática e verificabilidade em princípio" (1971, p.40). Essa peculiaridade configura uma importante distinção, uma vez que instaura uma duplicidade não ambígua sobre o conceito que se tem tratado no presente trabalho. No mundo cotidiano, em seu trato mais prosaico, as pessoas genericamente assumem como certas várias proposições sem que, no entanto, as tenham verificado, a fim de que possam garantir, de maneira razoavelmente justificada, a crença impingida a tais proposições. Muitas proposições não são verificadas, mas são verificáveis, isto é, em se querendo verificá-las, um método disponível se apresentaria para que essa tarefa fosse concluída.

A espécie a respeito da qual Ayer pretende fazer agir sua distinção é sobre aquelas proposições que aparentemente não estariam sob o âmbito da verificação imediata dos sentidos. Se o princípio de verificação se aplicar somente aos casos passíveis de verificação imediata, então se segue a isso que grande parte de nossas proposições científicas (por exemplo, proposições da cosmologia) seriam derrogadas por tratar-se de proposições sem possibilidade de determinação de verdade ou falsidade. Esse é um grave e incômodo caso que o positivismo procura afastar de seu empreendimento, e para tanto recorre ao conceito de possibilidade de verificação, em vez do contato imediato com o objeto em um momento indexado no presente.

Assim, supondo-se afirmações cosmológicas acerca da galáxia de Andrômeda, que é a mais próxima do nosso sistema solar, poderíamos imaginar uma série de questões que, de modo imediato aos sentidos, não estão disponíveis atualmente. Isso pode ocorrer porque não existe aparato tecnológico suficientemente desenvolvido para uma observação apurada, de modo que uma questão sobre quantas estrelas constituem a galáxia de Andrômeda pode resultar sem resposta. Embora isso seja compreensível, não estaríamos habilitados a dizer que essa pergunta não pode ser respondida. Pode-se ter, hoje, uma limitação que nos obste de 
conseguir essa informação e, talvez, essa informação nunca esteja disponível para a espécie humana.

Dessa maneira, a verificabilidade prática acerca do questionamento exemplar aqui sugerido parece vedada por uma enormidade de limitações que se tem atualmente no campo tecnológico-científico e que talvez jamais sejam superadas. Porém, isso não implica que é impossível obter a informação. Ayer afirma que é "teoricamente concebível" que esse tipo de informação seja obtido, mesmo que não o seja do ponto de vista da verificação prática.

$\mathrm{O}$ fato de não haver nenhum empecilho lógico que restrinja a possibilidade de obtenção da informação questionada leva à conclusão que, em princípio, a verificabilidade pode ocorrer, embora as limitações técnicas obstem a verificabilidade prática. Portanto, se a verificabilidade em princípio é possível, a verificabilidade pode ser conseguida. Schlick afirma que "o que só é impossível empiricamente, permanece cogitável e, portanto, possível. Ao contrário, o que é logicamente impossível, é contraditório e por conseguinte nem sequer é pensável"' (1988, p. 46)

Caso se tenha uma questão que pode estar no âmbito da espécie de verificação em princípio, segue-se, pelo antes exposto, que essa questão é uma questão de fato. Por esse motivo, tais questões são prenhes de sentido, na acepção dos positivistas lógicos.

Somente questões de fato poderão ser sondadas pelos meios de verificação disponíveis, haja vista serem elas as propositoras dos dados dos sentidos. Não se poderá estabelecer um método de verificação que confirme qualquer tipo de alegação que esteja para além das nossas capacidades sensoriais. A realidade transcendente da metafísica está fora do âmbito dessas capacidades sensoriais, portanto, não é possível verificar suas alegações.

O que há de central no princípio de verificação é a doação de sentido a uma frase, ou seja, se uma frase pode ser verificada, ela possui sentido, e caso não possa ser verificada, a alegação constante na frase não possui sentido, não podendo mesmo ser refutada. Refuta-se, portanto, a partir do princípio de verificação, não somente as frases individuais que não podem ser verificadas como sendo falsas, mas o conjunto de frases que, ao não se poder atribuir-lhes 'verdade' ou 'falsidade', colocam-se em um cenário que extravasa as condições necessárias que possibilitariam uma determinada designação de verdade. Desta feita, convêm passar-se à análise do que é o 'sentido', em uma acepção positivista lógica, para que o princípio de verificação continue a ser devidamente explanado. 


\subsubsection{O "Sentido" na Acepção do Positivismo Lógico}

Para Schlick, o início da atitude filosófica reflexiva precisa estar consciente da impossibilidade de ela ocorrer em um ambiente em que não está claro o modo pelo qual se fixa o sentido de uma frase. As "condições necessárias" são o cerne para que haja a compreensão de sentido. É óbvio que Schlick não pensava estarem essas condições necessárias suficientemente a contento no ambiente metafísico do qual privava e se contrapunha ${ }^{5}$. Seguindo esse raciocínio, ele manifesta que:

O sentido de uma proposição só pode evidentemente residir no fato de a mesma exprimir um determinado estado de coisas. Precisamente esse estado de coisas deve ser assinalado, se quisermos indicar o sentido da proposição (SCHLICK, 1988, 43-44).

Veja-se, então, o ponto em que esta análise se encontra: o princípio de verificação é o que pode nos levar à compreensão do que é o sentido de uma proposição. Se uma proposição não puder ser submetida à verificação, está destituída de sentido. No entanto, devemos submeter uma proposição à verificação para saber o que é o seu sentido, pois assim poder-se-á concluir se uma frase pode ou não ser cognitivamente relevante, isto é, poder-se-á saber se uma frase tem ou não sentido, concluindo-se, assim, um círculo virtuoso. Para apontar o que é o sentido de uma proposição, a estratégia de Schlick é primeiramente definir o que é um estado de coisas. Com isso, a linha de raciocínio se completa.

Para que haja um estado de coisas é necessário que exista um dado. São esses dados que irão compor a proposição e, destarte, as proposições, repletas de dados, estarão referindose a estados de coisas. Desse modo, seguindo esse formato, os estados de coisas estarão designados nas proposições. Tal como Schlick escreve, no texto abaixo citado:

... para encontrar o sentido de uma proposição, é necessário reformulá-la introduzindo definições sucessivas, até que ao final permaneçam apenas palavres que já não são passíveis de definição, mas cuja significação só pode ser demonstrada diretamente.

O critério para averiguar a verdade ou falsidade da proposição reside então no fato de que, em determinadas condições - indicadas nas definições - ocorrem ou não ocorrem certas coisas. Constatado isso, averiguado está tudo aquilo que se fala na proposição, e com isto conheço precisamente o seu sentido (SCHLICK, 1988, p.44).

Algumas coisas precisam ser decifradas aqui. Primeiro, acerca das definiçõos dos termos utilizados em proposições: Schlick imagina que se poderia encontrar uma definição tão razoavelmente bem assentada que ela não mais precise de novas definições. O critério

\footnotetext{
${ }^{5} \mathrm{O}$ contexto do aparecimento do Positivismo Lógico está, como já foi dito anteriormente, diretamente relacionado à oposição ao idealismo encampado por Bradley.
} 
utilizado é que se se puder constatar diretamente o conteúdo de uma definição, poder-se-á, enfim, articular um conceito verificado, estando ele, assim, cabalmente demonstrado. O que está demonstrado, portanto é o dado, pois “o sentido de uma proposição, em última análise, é determinado somente pelo dado, e nada mais" (SCHLICK, 1988, p.44).

Obviamente, Schlick não pensa que as definições constantes em uma proposição devem estar colocadas de modo imutável e, para afirmar isso, esclarecer-se-á o segundo ponto: o critério de verificação está relacionado a certas condições por meio das quais se pode constatar se uma definição é ou não é o caso. Estabelece-se, por essa via, um critério a partir do qual a avaliação e designação de verdade de uma definição são fixadas.

O critério preconizado pelo positivismo lógico é aquele em que a verificação dos dados consegue melhor êxito (ver Ayer, 1971, p. 57). Naturalmente, se o meio dileto do positivismo lógico é a via da constatação dos dados, e considerando que o único modo de fazê-lo é o meio empírico, então se conclui que o positivismo lógico precisa produzir ou adotar um método de verificação que possa subsidiar as pretensões de verdade ou falsidade de uma proposição. Aqui adentramos na escolha, reconhecimento e eleição que o positivismo lógico tencionar descortinar para estabelecer o modo mais acertado de configurar uma proposição cognitivamente relevante, a saber, a instauração do método científico como modus operandi das proposições com significado.

\subsection{As Proposições Sintéticas e as Proposições Analíticas}

Os positivistas lógicos, dado o que se pode ver acima, dividem as frases em duas grandes vertentes: as com sentido e as sem sentido. As frases com sentido são aquelas em que podemos afirmar em que condições elas são verdadeiras ou falsas. Essas frases estão de acordo com a inspiração positivista acerca do significado das proposições, que busca seu motivo na filosofia de Wittgenstein ${ }^{6}$ : "O sentido de uma proposição é seu método de verificação" ${ }^{7 "}$ (WITTGENSTEIN \& WAISMANN, 1979, p.79).

Na seção anterior abordamos a verificação, e diante do que foi dito concluímos que ela forma um princípio que é a pedra de toque para que uma frase seja considerada verdadeira ou

\footnotetext{
${ }^{6}$ Ludwig Wittgenstein foi um filósofo de importância central para o desenvolvimento do Positivismo Lógico. Isso se deve ao fato de o seu livro Tractatus Logico-Philosophicus, publicado pela primeira vez em 1921, com o título em alemão Logisch-philosophische Abhandlung, ter sido o maior contributo das teses principais que vemos florescer no positivismo. Na verdade, pode-se dizer que as teses do Positivismo Lógico estavam, de certa maneira, de modo embrionário nessa obra seminal de Wittgenstein. Schlick é seu confesso tributário, no tocante às principais questões desenvolvidas no círculo de Viena. Rudolf Carnap encontra no Tractatus Logico-Philosophicus a inspiração necessária para escrever a sua famosa obra Der Logische Aufbau der Welt, publicada em 1928. A influência de Wittgenstein nessa obra é marcante, embora as teses carnapianas recebam uma configuração própria e posteriormente revisem certos pontos específicos de sua própria obra.

7 "The sense of a proposition is the method of its verification"
} 
falsa, isto é, com sentido. Ao contrário, as frases sem sentido não podem ser verdadeiras ou falsas por uma razão análoga, qual seja, não podem ser verificadas. Nesse caso, vários conceitos que são utilizados no cotidiano carecem de sentido, e nessa perspectiva pode-se tomar como exemplo o conceito de Deus, que é um tema caro à metafísica.

Porém, qual é essa espécie de frase que pode ser verificada? Em que consiste sua verificação? Para responder essa pergunta, primeiro iremos caracterizar quais são as proposições com sentido. Segundo os positivistas lógicos, as únicas frases que podem receber um designador de verdade são as proposições, e elas dividem-se em sintéticas e analíticas ${ }^{8}$.

Proposições sintéticas são significativas na medida em que podemos verificá-las a partir da experiência. É nesse sentido que a verificação é compreendida mais amplamente. A princípio, a verificabilidade de proposições é formada a partir da experiência imediata. Posteriormente, motivados pelas insuficiências de uma definição tão restritiva, os positivistas lógicos empreenderam uma reformulação do conceito de verificabilidade, para tentar ajustá-lo às novidades da empolgante ciência da primeira metade do século $\mathrm{XX}^{9}$.

Em uma proposição sintética, sua verdade ou a falsidade está condicionada à verificação, na experiência, daquilo que é asseverado. Em proposições analíticas, a verdade e a falsidade de uma proposição não são verificáveis a partir da experiência. Proposições analíticas devem sua verdade ou falsidade à definição dos termos constantes na sua asseveração e à lógica interna estabelecida na frase.

O clássico exemplo de uma proposição analítica é “Todo solteiro é não casado". Ora, essa frase é verdadeira de modo independente da experiência. Não precisamos varrer o mundo a fim de verificar, por meio da experiência, que todo solteiro é um não casado. O que precisamos, em última instância, é saber as definições dos termos envolvidos na proposição.

Destarte, se por "solteiro" entendermos "aquele que não está casado e nunca se casou", seguramente poderíamos afirmar que todo solteiro é não casado. No entanto, não poderíamos dizer, com o mesmo rigor, que "Todo não casado é solteiro", caso não houvesse somente um mundo ou com solteiros ou com casados. Isso se deve, analogamente, a outras definições diversas, em que "não casados" não são exatamente solteiros. As definições de

\footnotetext{
${ }^{8}$ Essa distinção se deve a Immanuel Kant. Entretanto, a consideração dos positivistas lógicos sobre que tipos de frases são sintéticas e quais são analíticas diverge bastante do propositor da distinção. Kant pensa haver algo como juízos sintéticos a priori, conceito rejeitado pelos positivistas lógicos. No caso dos juízos analíticos, os positivistas lógicos afirmam que a matemática é analítica, divergindo de Kant, que afirma que a matemática pode ser categorizada como sintética e a priori. A distinção de Kant é encontrada em sua Critica da Razão Pura, em B10-B14 (2012 p. 51-53); A afirmação de que a matemática é sintética, e a priori está na introdução, de B14- B17 (2012 p. 53-55).

${ }^{9}$ Falaremos dessa mudança, de modo geral, ao longo de nossa exposição. Os artigos principais que expressam essa mudança são Sentido e Verificação, de 1936, de autoria de Schlick; e Testabilidade e Significado, de 1936, de Carnap. Esse último é o artigo central a esse respeito.
} 
"viúvo" e "divorciado" impedem que a frase "Todo não casado é solteiro" seja analítica. Se por "viúvo" entendermos "aquele que se casou e, posteriormente, teve que passar pelo luto de seu cônjuge", e por "divorciado" entendermos "aquele que se casou e, posteriormente, separou-se de seu cônjuge", certamente a frase "Todo não casado é solteiro" não poderá ser analítica.

Para se estar seguro acerca da verdade ou falsidade da frase "Todo não casado é solteiro" em um mundo com solteiros, casados, viúvos e divorciados, seria mister verificar todas as experiências reais para constatar que este é o caso. Só assim se estaria seguro no tocante ao valor de verdade da proposição. Desse modo, mesmo que a proposição não seja analítica, ela seria uma proposição sintética, pois podemos estabelecer sua verdade ou falsidade pela via da experiência. Portanto, ela seria uma frase com sentido.

Todavia, se tivermos um mundo onde só existam, forçosamente, ou solteiros ou casados, poderíamos estabelecer uma interdefinição entre os termos, segundo o qual por "solteiro" entender-se-ia "não-casado", e por "casado" entender-se-ia "não-solteiro". Se esse fosse o caso, então a proposição "Todo não casado é solteiro" seria uma proposição analítica, pois sempre que $\mathrm{X}$ fosse não-casado significaria que $\mathrm{X}$ é solteiro; e de igual modo, sempre que $\mathrm{X}$ fosse não-solteiro, $\mathrm{X}$ seria casado.

O que faz uma proposição ser analítica é (1) o fato de ser verdadeira em função da definição dos seus termos (ser verdadeira em razão do significado dos seus termos), ou dito de outro modo, o fato de serem tautológicas; e (2) ser verdadeira em função da lógica que está posta como pano de fundo às proposições.

Segundo essa definição de analiticidade, a proposição "Todo solteiro é não casado" se adequa a (1), e considerando o caso da interdefinição acima sugerida podemos afirmar que tal proposição está reduzida a uma verdade lógica. A proposição "Ou o gato é pardo ou o gato não é pardo" é verdadeira e se adequa ao que está posto em (2), e nesse caso específico a lógica que está a ser considerada é a razão da analiticidade da proposição em questão. $\mathrm{Na}$ circunstância aventada é a lógica de primeira ordem, e o que garante a verdade da proposição analítica é o princípio de não contradição. Assim, a verificabilidade assume um formato de demonstração, nos critérios descritos em (1) e (2).

Schlick afirma que as afirmações baseadas na experiência podem estar amparadas, por um lado, na relação sensorial cotidiana que estabelecemos com o mundo; e, por outro, nos postulados das ciências naturais. A diferença entre as duas, segundo ele, é uma questão de 
grau: aquela se fundamenta em uma experiência sensorial ingênua, sendo, portanto, bastante falseável, haja vista que os sentidos são facilmente iludidos; essa se fundamenta na metodologia científica para assegurar a verdade ou falsidade de suas proposições. Porém, ambas as alternativas fundamentam-se na experiência, ou seja, podem ser verificadas.

O grau de sofisticação na verificabilidade é, evidentemente, maior na ciência, por meio da metodologia científica. Isso se deve à preocupação que o cientista tem no que respeita as medidas que são tomadas para confirmar uma hipótese. Essas medidas são complexas e várias, e a tarefa do filósofo é proceder à análise dos conceitos que estão subscritos na conjuntura formulada pela inquirição hipotética, constante no itinerário científico. Segundo Rudolf Carnap,

\footnotetext{
Para analisar os conteúdos das cognições, a epistemologia deve investigar os objetos (conceitos) da ciência (empírica)

(...)

A análise epistemológica é uma análise dos conteúdos das experiências, mais precisamente a análise do conteúdo teórico das experiências. Preocupamo-nos somente com o conteúdo teórico da experiência, isto é, com o possível conhecimento que está contido na experiência (1988, pp. 143 e 145).
}

Isso quer dizer que as nossas pretensões de conhecimento do mundo estão conectadas à avaliação da melhor e mais refinada formulação disponível que se possui, qual seja, a formulação científica. Entretanto, o positivista lógico não é ingênuo, e por isso mesmo pronuncia um corpo de análise dos conceitos estatuídos ou supostos pela ciência. Veremos na próxima seção a abordagem do positivismo lógico com relação à linguagem científica.

\subsection{O Fisicalismo e a Modificação do Princípio de Verificação}

O filósofo Wolfgang Stegmüller afirma que Carnap defendeu uma linguagem unitária da ciência, o que quer dizer que a linguagem científica deveria estar estipulada sobre as mesmas bases linguísticas. Essa linguagem deveria atender a dois princípios: (1) ser intersubjetiva, ou seja, ser uma linguagem cujo significado fosse o mesmo para qualquer indivíduo; e (2) ser uma linguagem universal, ou seja, todas as frases poderiam assumir uma forma enunciativa em uma linguagem única a qual seriam reduzidas.

Carnap e Neurath chegaram a defender que a linguagem que poderia satisfazer as condições arroladas acima é a linguagem da física, e por isso essa proposta foi chamada de fisicalismo (STEGMÜLLER, 2012, p. 286). Embora a proposta do fisicalismo não tenha se 
sustentado $^{10}$, o fato de ter sido expressamente sugerida por membros centrais do Positivismo Lógico evidencia a importância das ciências naturais, precipuamente da física, para a configuração de uma linguagem que atendesse às expectativas de uma clareza quanto aos enunciados empíricos e ao seu método de verificação.

Outro aspecto importante que deve ser mencionado para esclarecer o fisicalismo é o raciocínio constante em filosofia segundo o qual chegamos a uma conclusão por meio da generalização provável de uma série de experiências passadas, sem que haja, entretanto, uma relação de necessidade entre a conclusão e as premissas. Essa espécie de raciocínio é conhecida como indução. Na definição dada por nós, o que deve ser enfatizado são as chances da ocorrência futura de uma experiência passada, ou seja, a probabilidade de um evento ocorrer. Esse raciocínio é bastante comum na ciência, e se o positivismo lógico privilegiou as ciências naturais (ou seu método de perquirição) é relevante dizer algumas palavras a esse respeito.

Alguns positivistas lógicos encamparam a ideia de que há um método comum às diversas ciências naturais que, em última análise, podem ser reduzidas à física, como está apresentado no artigo de Carnap, no qual ele diz que "A chamada tese do fisicalismo afirma que todo termo da linguagem da ciência - incluindo-se além da linguagem física aquelas sublinguagens que são usadas na biologia, na psicologia e na ciência social - é redutível aos termos da linguagem física" (1988, p. 194).

Como já falamos acima, essa tese é conhecida como fisicalismo. A unidade que foi percebida no método utilizado pelas varias ciências naturais foi o conceito de probabilidade, ou seja, todas as ciências naturais teriam em comum a forma de conceber suas conclusões pela via da verificação das experiências passadas, e a probabilidade de essas experiências anteriormente verificadas terem alta probabilidade de produzirem uma ocorrência futura, como foi exposto, brevemente, por Ayer:

... em linhas gerais, tudo o que expressamos ao dizer que uma observação aumenta a probabilidade de uma proposição é que aumenta nossa confiança na proposição, como calculada por nosso desejo de confiar nela, na prática, como em uma previsão de nossas sensações, e retê-la com preferência a outras hipóteses frente a uma experiência desfavorável (1971, p. 116).

\footnotetext{
${ }^{10}$ A proposta do fisicalismo encontrou muitas dificuldades de se fixar como um caminho viável para fundamentar a linguagem a qual todos os enunciados deveriam ser reduzidos. O exemplo dessa dificuldade é trazido à baila pelo próprio Stegmüller: o enunciado psicológico "O senhor X está irado, agora" parece irredutível a uma descrição que substitua todos os termos envolvidos por seus correspondentes termos substitutos em linguagem física de modo que os termos estejam, a uma só vez, concatenados por uma quantidade finita de enunciados; e que estejam, também, precisamente determinados.
} 
A probabilidade, nesse caso, seria um método legítimo para confirmação da conclusão. Uma parte do esforço dos positivistas lógicos vai ao encontro de uma solução para o problema da indução, ou melhor, para o problema da formalização do método indutivo. É notório o fato central com respeito à inspiração e ao mote consagrados no positivismo lógico, fato esse já aventado no início deste capítulo, em que a formalização da lógica dedutiva consignada por Frege "fez nascer a esperança de que se podia fazer o mesmo para a chamada 'lógica indutiva"” (PUTNAM, 1992, p.161) ${ }^{11}$

Nessa linha, por volta de 1936, faz-se uma modificação importante no princípio de verificação, em que a verificação é substituída por 'confirmação'. Em um artigo publicado nesse mesmo ano, Carnap afirma que "Se por verificação se entende um estabelecimento completo e definitivo da verdade, então uma sentença universal, por exemplo, uma assim chamada lei da física ou da biologia, nunca pode ser verificada”, e continua seu raciocínio: "Não podemos verificar a lei, mas podemos testá-la, testando suas instâncias particulares, isto é as sentenças particulares que deduzimos da lei e de outras sentenças previamente estabelecidas; sendo assim "Se na série contínua de tais experimentos de teste não se encontrar nenhuma instância negativa, mas o número de instâncias positivas aumentar, então nossa confiança na lei aumentará passo a passo". Para Carnap, "ao invés de verificação, podemos falar aqui de confirmação gradativa crescente da lei” (1988, pp. 172 e 189).

Ora, nota-se claramente que Carnap vê certas dificuldades inerentes ao imediatismo das observações requeridas pelo verificacionismo inicialmente constituído a partir de uma noção radical de empirismo. O aparente abrandamento do principio de verificação se dá pela consagração de uma forma um tanto quanto especial, a qual essa verificação se comuta, qual seja, o formato de considerar prova suficiente os resultados esperados extraídos de um determinado experimento. Por meio dos testes realizados reiteradamente, confirma-se aquilo que não pôde ser verificado de modo direto. No entanto, Carnap afirma que a confirmação pode ser reduzida à verificação dos resultados desses experimentos, esses sim observáveis diretamente e passíveis de sucessivas verificações (CARNAP, 1988, p. 209).

Embora Carnap procure um conceito melhor que o de 'verificação' para designar o modo como se estabelece a verdade ou falsidade de uma proposição sintética, o conceito de ‘confirmação’ pode ser, segundo ele, reduzido àquele, e isso é visível na afirmação de que

\footnotetext{
${ }^{11}$ Obviamente, esse empreendimento fracassou, como é atestado pelo próprio Putnam ao fazer referencia a reflexão filosófica de Nelson Goodman.
} 
certos tipos de predicados que não são observáveis podem ser redutíveis a predicados observáveis (1988, p.193).

Putnam, dando início à sua crítica ao Positivismo Lógico, nota isso com clareza, e de modo perspicaz, ,quando diz que embora haja uma ampliação do conceito de verificabilidade, ainda persistiam os dois pontos seguintes:

(1) uma condição necessária que um enunciado devia satisfazer para ser considerado como "cognitivamente significativo" era a de ser expressável na "linguagem da ciência" (tal como formalizada pelos positivistas lógicos) e (2) os predicados admitidos na parte "factual" da linguagem da ciência tinham de ser "termos de observação" ou redutíveis a termos de observação (PUTNAM, 2012, pp. 39-40)

A consequência disso, conforme observado por Putnam, é que a alternância do conceito de verificação para o conceito de confirmação não estabelece, por si só, a extinção dos problemas e, ademais, traz consigo outras questões incômodas, tais como a ausência de sentido dos termos 'elétron' e 'bactéria', por exemplo, a não ser que eles fossem reduzidos a termos observacionais que não se lhes referissem diretamente (PUTNAM, 2008, p. 40). Em todo o caso, o cerne do princípio de verificação anteriormente definido permanece o mesmo, qual seja, a possibilidade de um contato pela via do nosso aparato sensorial ou, dito de outro modo, a observação dos termos envolvidos na proposição sintética.

\subsection{As Consequências Éticas do Positivismo Lógico}

Diante do que foi dito nas sessões anteriores, qual é a posição do positivismo lógico diante das questões éticas? Segundo o próprio Carnap, os valores éticos não possuem relação com a verdade ou falsidade (1988, p. 166), de tal modo que as frases dessa categoria são pseudoproposições, cujo principal apanágio é não poderem estar aclaradas sob a luz da aplicação de um método de verificação.

Ayer afirma que não há, no âmbito epistemológico a ser considerado pelo positivista lógico, lugar para as questões de valor, mas, antes, uma prevalência das questões de fato (1971, p. 129). A decorrência disso é a ausência da possibilidade de atribuir um valor de verdade aos enunciados éticos. Os enunciados éticos são ou expressões normativas da moral, ou expressões emotivas (1971, p. 125).

Como foi visto anteriormente, o tratamento deferido pelo positivismo lógico a essa ciência tem o seu cerne na redução a ciências naturais a que elas serão submetidas. Em última 
análise, a ética, bem como qualquer tipo de conjunto de enunciados, não tem independência das ciências naturais, e só poderão ser considerados compatíveis com o programa do positivismo lógico no caso de estarem bem assentadas em termos empíricos. Contudo, não se está a postular uma teoria naturalista em ética, conquanto a abordagem emotivista pretenda-se compatível ao empirismo radical assumido pelo positivismo lógico.

Isso acontece em razão de as manifestações emotivas não se referirem às questões de fato, mas serem expressões subjetivas de um estado mental de um indivíduo, de modo que uma frase como "Eu estou aborrecido" é verdadeira se, e somente se, o indivíduo emissor da frase estiver realmente aborrecido (AYER, 1971, p.127). Esta alegação de um estado mental subjetivo não é incompatível com o empirismo porque sua verdade ou falsidade não se refere a uma questão de fato, mas a um sentimento.

Outrossim, a frase "matar é errado" é uma alegação do mesmo jaez, e pode ser traduzida a um enunciado subjetivista da forma "Eu acho que matar é errado", de tal maneira que a frase só poderá ser verdadeira ou falsa na medida em que o indivíduo que a emite realmente achar que a ação de matar é errada, embora matar não seja, de modo independente de um julgamento subjetivo e emocional, errado. Sabedores disso, os positivistas lógicos não propõem uma teoria ética que se refira a questões de fato, tal como não se poderia alegar que acontece no caso do enunciado "É errado matar", mas tão somente, propõem manifestar um estado psicológico geral, este sim verdadeiro ou falso na perspectiva do indivíduo que afirma "Eu acho que matar é errado".

Destarte, a ética não está ligada a questões de fato, posto que somente se refira a estados emocionais psicológicos reais. Parece consensual, no programa positivista lógico, que enunciados éticos contrariam seu pressuposto básico, a saber, que enunciados cognitivamente relevantes devem dizer respeito à experiência, que é o que fundamenta as questões de fato.

No próximo capítulo, analisaremos a distinção radical que o positivismo lógico promoveu entre questões de fato e questões de valor, a partir da distinção entre proposições sintéticas e analíticas. A distinção entre questões de fato e questões de valor, elevada à dicotomia, será criticada por Putnam, que argumentará que a noção de fato do positivismo lógico está equivocada, uma vez que o próprio positivismo lógico não obtém êxito em sustentar seus pressupostos adotados. À reflexão do círculo de Viena também é característico não ser capaz de explicar o papel dos valores nos enunciados factuais, e Putnam concluirá que questões de valor podem ter sentido não sendo, portanto, destituídas de qualquer relevância cognitiva. 


\section{CAPÍTULO II: DO NÃO COGNITIVISMO AO COGNITIVISMO DOS ENUNCIADOS ÉTICOS - A MUDANÇA NAS NOÇÕES DE FATO E DE OBJETIVIDADE}

Este capítulo será dividido em duas partes. Na parte inicial, procuraremos mostrar que o positivismo lógico, trabalhado no primeiro capítulo, é tributário de uma noção de fato herdada do empirismo clássico. A via de introdução dessa noção de fato está na dicotomia analítico/sintético $^{12}$, muito importante para o positivismo lógico, na qual o método de verificação de enunciados sintéticos exige que o conceito de fato esteja bem precisado. Nosso interesse é revelar a consolidação dessa dicotomia ${ }^{13}$, que em muitos aspectos é análoga à dicotomia entre fato e valor. Ambos os binômios conceptuais, que de início eram simples distinções, tornaram-se dicotomias por meio de uma inflação dos seus conceitos.

Com efeito, será exposta a estratégia de Putnam, que é apresentar a dicotomia entre os juízos analíticos e sintéticos, a fim de revelar que uma distinção não é uma dicotomia, e ao mesmo tempo criticar a noção de fato dos positivistas lógicos. Posteriormente, objetaremos que essa noção de fato dos positivistas lógicos possa ser sustentada pelos pressupostos adotados por eles. Nossa intenção é argumentar que a noção de fato do positivismo lógico está equivocada, haja vista que ela não é capaz de explicar o papel dos valores nos enunciados factuais, destituindo-os, assim, de qualquer relevância cognitiva.

Na segunda parte, apresentaremos a dicotomia fato/valor, mostrando o périplo do argumento putnamiano, que irá nos revelar o imbricamento entre as noções de fato e valor. A consequência desse imbricamento é que a dicotomia é fragilizada ao ponto de não se sustentar, restando somente a distinção. Putnam irá argumentar, por conseguinte, que os enunciados de fato são valorativos, e que enunciados de valor são factuais.

Assim, é interessante apresentar o raciocínio que revelará a Putnam a constatação da fratura interna de uma dicotomia (analítico/sintético), impetrado por Quine ${ }^{14}$, para,

\footnotetext{
${ }^{12}$ Putnam discorre demoradamente sobre aspectos gerais da dicotomia em The analytic and the synthetic. In: Mind, Language and Reality, Philosophical Paper, Vol. 2; e 'Two dogmas' revisited In: Realism and Reason, Philosophical Paper, Vol. 3.

${ }^{13}$ Não temos o intuito de fazer uma análise crítica da distinção entre o analítico e sintético. Nosso objetivo, ao analisar essa distinção, é apresentar a formação de uma dicotomia, ao invés de expor os motivos pelos quais muitos enunciados não podem ser classificados como analítico ou sintético, de maneira estanque.

${ }^{14}$ Quine é o autor do artigo Dois Dogmas do Empirismo, no qual ele apresenta a questão de um dos dogmas, a divisão entre as verdades analíticas e as verdades sintéticas estar mal fundamentada. Putnam não se delongará na argumentação quineana sobre a dicotomia analítico/sintético, pois não é o argumento de Quine em si que está no centro de sua análise. O que nos interessa aqui é mostrar que a distinção entre o analítico e o sintético não leva a uma dicotomia, bem como no caso da distinção entre os juízos de fato e os juízos de valor.
} 
posteriormente, chegarmos à ideia principal do solapamento da dicotomia fato e valor. Depois disso feito, poderemos considerar a suposição da objetividade (de alguns) dos valores (éticos).

\subsection{O Pano de Fundo do Empirismo Clássico}

O positivismo lógico, que Putnam faz uso para iniciar a sua crítica, apresenta uma versão tripartite dos juízos, que compreende as duas dicotomias aqui aventadas: os juízos sintéticos, que são verificáveis empiricamente; os juízos analíticos, que podem ter um valor de verdade a si atribuído simplesmente em virtude do significado dos termos constantes nessa classe de enunciados, prescindindo, desse modo, de verificações empíricas; e, por fim, os juízos éticos, metafísicos e estéticos, que são aqueles juízos não cognitivos, ou seja, juízos destituídos de significado.

A primeira coisa a ser dita parte do ponto da caracterização do âmbito ao qual a dicotomia analítico/sintético pode ser aplicada. Segundo a distinção entre analítico e sintético, os enunciados da linguagem que são cognitivamente relevantes poderão ser verdadeiros ou falsos, consoante os critérios da classe aos quais se referem. Assim, serão verdadeiros ou falsos, do ponto de vista da classe de enunciados analíticos, em razão das regras lógicas do enunciado, dessa forma prescindindo da experiência; e serão verdadeiros ou falsos, do ponto de vista de enunciados sintéticos, em razão dos testes experimentais, passíveis de observação.

A linguagem cotidiana, ao contrário da linguagem cognitivamente relevante, é limitadora, pois nela recorrentemente há uma possibilidade de confusão, ou melhor, uma imprecisão habitual nos seus termos, na ausência de uma forma, e na possibilidade de constatar a verdade ou falsidade de seus enunciados (por meio verificacional). Quando a linguagem torna-se cognitivamente relevante, resulta que os enunciados serão verdadeiros ou falsos e, por isso mesmo, ou passíveis de teste segundo o modelo observacional, ou demonstráveis segundo suas regras da linguagem constituída ${ }^{15}$.

Da mesma forma que Putnam nos demonstrará com relação à dicotomia fato/valor, ele nos ensina que a dicotomia analítico/sintético, ora abordada, assumiu, também, um tom onipresente (PUTNAM, 2008a, p. 23-24). Isso significa que todos os juízos recairão sob essa classificação que tem pretensão universal, no tocante a juízos com significados. Assim, todo juízo cognitivamente relevante é ou analítico, ou sintético. Os demais juízos fazem parte do conjunto de juízos cognitivamente não relevantes.

\footnotetext{
${ }^{15} \mathrm{O}$ caso de certos enunciados serem demonstráveis em virtude do significado dos termos constantes no enunciado.
} 
Os positivistas lógicos fizeram a totalidade dos juízos cognitivamente relevantes repousarem nas categorias de sintético ou analítico. Desse modo, dada a universalidade da aplicação da dicotomia metafísica, todos os juízos (cognitivamente relevantes) estariam inseridos em uma ou outra categoria. Portanto, os enunciados científicos deveriam ser classificados segundo esse estatuto. A física teórica, por exemplo, estaria no conjunto de enunciados que deveriam ser classificados dessa maneira para que pudessem receber a chancela de racional. Isso quer dizer que tais enunciados só seriam significativos caso pudessem ser formulados de modo a gerar uma resposta que indicará se eles são analíticos ou sintéticos, distintamente (2008a, p. 25).

Quine, ao contrário, empreende uma sequência que vai em direção à dissolução completa não só da dicotomia, mas também da distinção ${ }^{16}$ entre o analítico e o sintético. Se o sintético e o analítico fossem exemplificados de forma metafórica pelas cores "branco" e "preto", estariam, seguindo a metáfora, mais próximo da cor "cinza", o que simbolizaria o caráter não distinguível de ambos os enunciados ${ }^{17}$ :

O saber de nossos pais é um tecido de sentenças. Em nossas mãos, ele se desenvolve e transforma, por meio de nossas próprias revisões e adições mais ou menos arbitrárias e deliberadas, mais ou menos diretamente ocasionadas pelo estímulo contínuo de nossos órgãos sensoriais. É um saber cinza pálido, preto para o fato e branco para a convenção. Mas não encontrei razões substanciais para concluir que exista nele algum fio totalmente preto ou totalmente branco (QUINE, 1963, p. 406 apud PUTNAM, 2008a, pp. 25-26).

Segundo Putnam, esta ideia de que não há qualquer distinção entre as duas classes de juízos não deve ser levada tão longe, uma vez que ele próprio aceita que certos juízos são ou analíticos ou sintéticos. Porém, o que ele retém da crítica de Quine e, consequentemente, aceita como uma sugestão reproduzível no caso da dicotomia fato/valor é a observação de que determinados juízos cognitivos não recaem nos tipos de classes 'analítico' e 'sintético'. (PUTNAM, 2008a, p. 26). Igualmente, Putnam faz uma importante consideração que merece destaque, a saber, que se temos que determinado tipo de juízo não pode ser classificado como

\footnotetext{
${ }^{16}$ Em Os dois dogmas do empirismo ele rejeita a distinção entre os chamados "juízos analíticos” e os "juízos sintéticos”: "Minha proposta atual é que é um contrassenso, e a base para muitos outros contrassensos, falar de um componente linguístico e de um componente factual na verdade de qualquer enunciado individual. Tomada coletivamente, a ciência tem sua dupla dependência da linguagem e da experiência, mas essa dualidade não é significativamente delineável nos enunciados da ciência tomados um a um. (QUINE, 2011, p. 66). Embora pareça, ao contrário do que pensa Putnam, que Quine rejeita a distinção absoluta, que tem como consequência a dicotomia. ( ver QUINE, 2011, p. 71). Não obstante, a interpretação de Putnam está corroborada pelo texto supracitado.

${ }^{17}$ Putnam lembra que Quine, ao lançar uma crítica ao positivismo lógico em seu artigo intitulado Carnap and Logical Truth, dirige-se, em primeiro lugar, para a distinção clara e estanque que os positivistas lógicos fazem com respeito aos aspectos inter-teóricos, como a elegância (contraparte convencional) e o teste experimental dos enunciados hipotéticos (o que os positivistas chamam de 'fato'). Segundo ele, um elemento de convenção é uma característica que poderá, quando adotada anteriormente, ser posteriormente submetida a testes. A citação de Quine que Putnam recupera escapa ao âmbito teórico específico à linguagem científica, mas não à linguagem que os positivistas lógicos considerariam factual, ou seja, falseável por poderem ser submetidas a testes baseados em experiências concretas. Desse modo, recaem tanto os enunciados científicos da física, que são sintéticos, quanto o "saber de nossos pais", no âmbito do factual, por serem ambos passíveis de verificações a posteriori.
} 
sendo verdadeiro simplesmente em razão das regras lógicas (analítico), ele não deve recair como sendo um enunciado sobre questões de fato ou enunciados do tipo sintético.

Nessa esteira, Putnam declara que pode ser feita uma crítica ao caráter compulsório da dicotomia analítico/sintético, em que ambos os lados da dicotomia são naturalizados, ou seja, são consideradas as únicas classes básicas de enunciados com sentido. Dessa forma, insere-se nessas duas classes básicas de enunciados uma característica essencial compartilhada, qual seja, a de que juízos não analíticos são complementares aos juízos analíticos, e suas propriedades intrínsecas alternam-se sempre que um juízo passa de uma classe para outra.

Outrossim, sempre que os juízos não forem verdadeiros em razão das regras da linguagem lógica, serão juízos com a propriedade de serem "descrições de fato, em que o modelo original de um fato é o tipo de fato empírico que se pode figurar" $(2008$, p.27). A dificuldade aqui verificada é o fato de não se perceber outros tipos de enunciados que não sejam trivialmente verdadeiros, ou seja, que existe uma categoria de enunciados cognitivamente relevantes que escape à categoria dos juízos não analíticos típicos.

Como será possível ver, a dicotomia analítico/sintético tem muito a revelar no tocante à dicotomia fato/valor, aqui privilegiada, pois ambas possuem desenvolvimentos semelhantes. Putnam nos faz atentar para um ponto em comum, dos mais centrais, para o qual estas duas dicotomias convergem, e que as fundamenta em sua história conceptual, qual seja, a Lei de Hume $^{18}$. Segundo esta lei, grosso modo, não podemos derivar um 'deve' a partir de um 'é'19. Isso significa que nenhuma noção ética pode ser inferida de uma questão de fato, o que impossibilitaria de se ter um juízo moral ancorado em um fato da realidade.

Mas o fundamental da Lei de Hume, para Putnam é outro. Para o filósofo, o tema da inderivabilidade não demonstrável exposta na Lei de Hume não tem seu cerne simplesmente naquilo que diz respeito à questão inferencial, donde não poderíamos, claramente, apresentar como teorema a passagem lógica do 'é' para o 'deve'. Segundo ele:

\footnotetext{
${ }^{18}$ Putnam parece seguir a interpretação quineana de que a "distinção kantiana entre verdades analíticas e sintéticas já se prefigurava na distinção de Hume entre relações de ideias e questões de fato". (QUINE, 2011, p. 37) Do mesmo modo, a dicotomia fato/valor encontra nessa distinção de Hume o ponto de partida de sua formação.

${ }^{19} \mathrm{O}$ trecho do texto de Hume que se refere abertamente à famosa Lei de Hume é o seguinte: "Em todo sistema de moral que até hoje encontrei, sempre notei que o autor segue durante algum tempo o modo comum de raciocinar, estabelecendo a existência de Deus, ou fazendo observações a respeito dos assuntos humanos, quando, de repente, surpreendo-me ao ver que, em vez das cópulas proposicionais usuais, como é e não é, não encontro uma só proposição que não esteja conectada a outra por um deve ou não deve. Essa mudança é imperceptível, porém da maior importância. Pois como esse deve ou não deve expressa uma nova relação ou afirmação, esta precisaria ser notada e explicada; ao mesmo tempo, seria preciso que se desse uma razão para algo que parece totalmente inconcebível, ou seja, como essa nova relação pode ser deduzida de outras inteiramente diferentes”. HUME, David. Tratado da Natureza Humana. Tradução de Débora Danowiski. Livro III, Parte I, Seção II. São Paulo, Editora UNESP, 2000, p. 509
} 
Se a afirmação fosse simplesmente acerca da forma de certas inferências, ela proibiria qualquer um de inferir "deve-se fazer $x$ em tais e tais circunstâncias" a partir de "em tais e tais circunstâncias, é bom fazer $x$ e, nessas circunstâncias, é mau deixar de fazer $x$ ". Por certo, muitos filósofos responderiam a esse exemplo dizendo que ele não entra em conflito com o dictum de Hume, porque é um caso de inferência de um "deve" a partir de outro "deve". Mas esse é o meu ponto. A habilidade deles de reconhecer enunciados tais como "em tais e tais circunstâncias, é bom fazer $x$ e, nessas circunstâncias, é mau deixar de fazer $x$ " como um caso de "deve" não resulta de alguma característica da forma do enunciado mas, antes, de um entendimento do seu conteúdo (PUTNAM, 2008a, pp. 28-29)

Esta consideração é reveladora de um aspecto metafísico componente da percepção do problema do ponto de vista humeano, pois toma como motor da Lei uma constatação dos enunciados, que incluem o 'deve', não do ponto de vista lógico, demonstrando, assim, que a questão é muito mais profunda do que uma simples consideração formal. Essa inclusão da centralidade do conteúdo, ao invés do privilégio do modo inferencial, que objetaria que a passagem do 'é' para o 'deve' acarreta a invalidade do procedimento lógico, nos conduz a uma perspectivação do problema que é, quando colocado assim, dimensionado de outra maneira. Destarte, a centralidade do conteúdo exigirá que tenhamos em consideração aquilo faz, para Hume, que um enunciado seja um enunciado de 'é', pois assim entenderemos o que ele quer dizer com a noção de 'fato'.

A observação que Putnam faz nos lembra que Hume considera, em sua teoria da mente, que os conceitos são espécies de ideias, e estas são figurativas. Desse modo, as ideias humeanas somente representam "questões de fato" quando a elas se assemelham (2008a, p.29), o que significa que as figuras são formadas a partir de nossa experiência sensível, que é, também, o lastro no qual estará amparado a noção última de fato.

Com isso, pode-se perceber que Hume não interpõe a sua "Lei" meramente à impossibilidade da passagem de enunciados factuais a enunciados valorativos, mas que, em razão da maneira como as ideias recomendam a noção de fato, não há, no tocante às virtudes, realmente nenhuma "questão de fato ${ }^{20 "}$. O motivo pelo qual isso não ocorre é porque, com relação às virtudes, não temos como formar uma imagem figurável das propriedades de uma determinada virtude hipotética, ao passo que poderíamos, sem a menor dúvida, fazer figurar as propriedades de uma flor qualquer, por exemplo.

Entre o analítico e o sintético, ambos os lados da dicotomia assinalam uma série de propriedades ou características que são, entre si, distintivas. O mesmo ocorre com a dicotomia fato/valor, pois, segundo o entendimento de Putnam, os juízos que envolvem a noção de

\footnotetext{
${ }^{20}$ Para corroborar isso, segue o texto do próprio Hume: "Se o pensamento e o entendimento sozinhos fossem capazes de fixar os limites do certo e do errado, a qualidade de virtuoso ou vicioso teria de estar em algumas relações de objetos, ou então ser uma questão de fato, descoberta por nosso raciocínio." (HUME, 2009, pp. 502-503).
} 
“deve" são a parte do lado valorativo ao qual está vedada uma relação com os juízos de fato. Algumas palavras também se refeririam a essa classe de juízos, tais como "correto", "errado", "bom”, “mau”, quando usados, evidentemente, em suas acepções éticas ${ }^{21}$ (2008a, p. 31). Essa distinção humeana, quando inflada, ou seja, levada ao extremo da distinção, impõe que não teremos, e não poderemos ter juízos de fato que se refiram à ética. Desse modo, o argumento pode ser colocado da seguinte maneira:

(1) O que nos possibilita chamar algo de factual, ou seja, ser um enunciado de fato, é conseguirmos percebê-lo por meio do nosso aparato sensório (ter uma impressão), sendo, somente assim, passível de representação.

(2) São "objetos" somente aquelas entidades que podem ser capturadas por meio do aparato sensório.

(2.1) Ser capturado por meio do aparato sensório confere "objetividade" à entidade assim capturada.

(3) Se somente podemos atribuir objetividade aos objetos, então todos aqueles enunciados que não correspondam a enunciados factuais não são objetivos. 1 e 2 .

(4) Os enunciados de "deve" não podem ser capturados pelo aparato sensório.

Portanto, os enunciados de "deve" não são enunciados objetivos. 3 e 4.

O argumento, que é uma reconstrução que remete a Hume, apesar de válido, só pode estar correto se suas premissas forem verdadeiras. Desse modo, a tarefa de Putnam será reconfigurar a noção de fato. Ele usará, como estratégia, a apresentação do solapamento da dicotomia fato e valor.

Segundo a divisão apresentada por Putnam, há uma necessidade no tocante à inclusão dos enunciados em uma ou outra classe de enunciados analíticos ou sintéticos. Como já foi dito, se um enunciado (cognitivamente relevante) não for analítico, necessariamente esse enunciado (cognitivamente relevante) será um enunciado não analítico. Forçosamente, em razão da dicotomia, todo enunciado não analítico é um enunciado sintético. De modo análogo, todo enunciado não ético (correlacionado a "deve") é, necessariamente, um enunciado de fato. (2008, p. 32).

Essa fórmula dicotômica repercute de maneira clara no modo como os objetos são configurados, pois a distinção, inflada até tornar-se dicotomia, subsidia o formato metafísico

\footnotetext{
${ }^{21}$ Quando falamos que um sapato é bom, ou que uma operação aritmética está errada, não usamos "bom" e "errada" em acepções éticas. Obviamente, a classe resultante da coleção de enunciados de "deve", e seus correlatos, são aqueles usados na acepção ética.
} 
assumido, no qual ou se é um enunciado de fato, ou se é um enunciado de valor. Não há, aqui, lugar para a classe que Quine, recuperado por Putnam, chama de "cinza", mas tão somente para as classes "preto" e "branco".

A respeito do que temos falado, cabe lembrar que os "valores" em questão sempre são tratados, dentro da história da dicotomia, como valores éticos, omitindo-se, habitualmente, qualquer emergência de valores que não sejam éticos ${ }^{22}$. Putnam alega que "Desde Hume o fato de que existam muitos tipos de juízos de valor que não são em si mesmos de uma variedade ética (ou moral) tende a ser colocado de lado nas discussões filosóficas da relação entre os (chamados) valores e os (chamados) fatos" (2008a, p. 34).

Assim, os valores não éticos não têm sido considerados, e a dicotomia, inflada dessa maneira, omite uma importante categoria que poderia lançar nova luz ao problema. É isso que Putnam também resgatará dentro de sua estratégia argumentativa.

Putnam faz uma importante consideração sobre a natureza da dicotomia. Sua reflexão é que se tivermos o binômio fato/valor considerado somente no âmbito de uma importante distinção conceitual filosófica, não se seguirá dela nenhuma metafísica, do mesmo modo que não se segue nenhuma metafísica do fato de distinguir-se entre enunciados relativos à química e enunciados que não são relativos à química, por exemplo (2008a, p.35).

A importância da distinção estaria posta pela obviedade de que fato e valor não são sinônimos, e por isso mantêm peculiaridades e acepções específicas com respeito ao seu significado. Porém, ao traçar a distinção, não há nenhuma necessidade de uma decorrência metafísica ocasionada pelo que temos chamado de "dicotomia". Afinal, distinguir a cor "azul" da cor "amarelo" não é o mesmo que afirmar que elas são dicotômicas, por exemplo.

Na próxima seção, passaremos à análise da noção de fato que os positivistas lógicos adotaram, para lançarmos uma crítica com respeito aos pressupostos nos quais ele mesmo se ampara e fundamenta. Feito isso, poderemos começar a apresentação do argumento que irá culminar no colapso da dicotomia entre fato e valor.

\footnotetext{
22 Temos, também, como exemplo de valores que não são nem éticos ou não éticos os valores estéticos. Entretanto, estes padecem do mesmo problema considerado na dicotomia, pois não são factuais e cognitivos. Putnam deixa isso claro na parte II do livro "O Realismo de Rosto Humano", de 1999, intitulada "Ética e Estética".
} 


\subsubsection{A Critica de Putnam à Noção de Fato do Positivismo Lógico}

Pelo que vimos até aqui, podemos afirmar que a dicotomia entre fato e valor repousa sobre a noção de fato. Putnam nos explica que "a noção humeana de um 'fato' é simplesmente aquilo do qual pode existir uma 'impressão' sensível” (2008a, p. 38). Como já foi aventado acima, essa noção de fato é constitutiva da consolidação da dicotomia entre fato e valor e, dito de outro modo, isso pode ser asseverado por não possuirmos, no nosso aparato sensório, um sentido que consiga perceber uma virtude da mesma maneira que conseguimos perceber uma árvore. Isso limita nosso campo de possibilidade a afirmações factuais. Não temos um órgão sensorial que nos possibilite ter uma impressão do "bem", ou do "correto". Portanto, do ponto de vista da filosofia de Hume, estaríamos fadados a ter que manter enunciados éticos separados dos enunciados de fato.

Essa noção de fato foi muito influente na tradição analítica inaugurada pelo Círculo de Viena $^{23}$. Essa tradição estava temporalmente distante do empirismo clássico, porém, algumas de suas noções iniciais estavam muito de acordo com ele. Podemos dizer, juntamente com Putnam, que a noção de fato adotada inicialmente pelos filósofos do Círculo de Viena era bastante semelhante ao que Hume declara que ela $e^{24}$.

Putnam nos diz que “a visão positivista lógica original era de que um 'fato' era algo que podia ser certificado por mera observação e até mesmo por um mero relato de uma experiência sensorial.” (2008a, p. 39). Assim, os positivistas esperavam poder fornecer ou encontrar um método de verificação que pudesse estabelecer a justificação racional, e esse método, ou métodos, deveriam dar conta de verificar as pretensões cognitivas lançadas pelas diversas classes de enunciados (PUTNAM, 1992, p. 141).

Esses métodos de justificação racional, almejados pelos positivistas lógicos, que encerram a verificação (ou, abstratamente, a demonstração ${ }^{25}$ ), procurarão, assim, arrolar a forma por meio da qual a testabilidade, e a própria descrição dos métodos de justificação racional, poderá dar conta do significado dos enunciados. Essa é uma concepção criteriosa da racionalidade, "segundo a qual existem normas institucionalizadas que definem o que é e o que não é aceitável racionalmente" (1992, p. 146). É intrínseco à concepção criteriosa da racionalidade que esses critérios tenham um caráter público, de forma que deles possam fazer uso qualquer indivíduo que saiba deles dispor.

\footnotetext{
${ }^{23}$ O primeiro capítulo desse trabalho será dedicado a investigar as decorrências dos pressupostos adotados pelo Círculo de Viena para a ética.

${ }^{24}$ Embora os positivistas lógicos tivessem abandonado noções humeanas como "ideia" e "impressão", para citarmos dois exemplos.

${ }^{25}$ Trata-se de demonstrações lógicas. No caso do critério de que os enunciados cognitivamente relevantes devam ser passíveis de verificação e testes, estamos a falar de enunciados sintéticos; no caso daqueles que são verdadeiros ou falsos em razão das regras lógicas e significado dos termos, estamos a falar dos enunciados analíticos.
} 
Desse modo, os enunciados que não puderem ser submetidos ao método serão declarados carentes de significado. Destarte, se um enunciado não puder ser comprovado pelos meios colecionados, quais sejam, métodos matemáticos, métodos lógicos, ou métodos científicos $^{26}$, seguir-se-á que não haverá significado cognitivo algum que lhe seja relevante (1992, pp. 141-142). Esse crivo pelo qual devem passar os enunciados com pretensões cognitivas deve ser aplicado a todas as espécies de enunciados.

Entretanto, Putnam afirma, como foi supracitado, que os positivistas, ao fim e ao cabo, possuíam uma noção de fato que estava profundamente ligada à verificação pela via sensorial, ou, dito de outro modo, "que um enunciado significativo deve ser conclusivamente verificável por confrontação com a experiência direta" (PUTNAM, 2008a, p.39). Isso não se ajusta, em muitos casos, à adoção da via científica como critério, porque o método científico, várias vezes, postula a existência de entidades que não podem ser percebidas pelos nossos sentidos, como por exemplo, os átomos. Por isso, Putnam nos explica que as mudanças da ciência, na primeira metade do século XX, foram centrais para as sucessivas mudanças por parte dos positivistas lógicos, que objetivavam salvar a noção de fato.

Apesar das mudanças científicas importantes que ocorriam na época, como por exemplo, a física quântica, a teoria da relatividade, as primeiras descrições da estrutura interna do átomo e, apesar de os positivistas lógicos não terem ficado impassíveis diante disso, a noção de fato assumida pelo positivismo lógico permaneceu intacta. Putnam explicanos que os positivistas lógicos estiveram próximos da noção humeana de fato até por volta de $1936^{27}$. Nesse ano, Carnap flexibiliza o pressuposto "de que todos os predicados factuais devem ser definíveis em termos de observação" (2008a, p. 39).

A mudança é importante, mas a posição do positivismo lógico permanece inalterada em sua parte mais central, uma vez que para um enunciado ser considerado cognitivamente relevante, no que toca ao seu significado, fazia-se necessário que esse enunciado pudesse expressar-se por meio da linguagem científica; e que os predicados constantes na parte factual do jargão científico deveriam apresentar pelo menos uma das duas condições: serem termos coligidos por observação; ou serem redutíveis a termos de observação (2008a, p. 40).

\footnotetext{
${ }^{26}$ É importante notar que até a publicação da obra de Carnap intitulada Logical Foundations of Probability (1950), os positivistas lógicos supunham haver, segundo Putnam, "um método formal (lógica indutiva), e que o trabalho continuado podia resultar numa enunciação explícita deste método, uma formalização da lógica indutiva comparável à formalização da lógica dedutiva que fora realizada partindo da obra de Frege 1879" (PUTNAM, 1992, pp. 233-234). As características dessa convicção serão estudadas no capítulo 1 deste trabalho, quando da descrição geral do positivismo lógico.

${ }^{27}$ Putnam usa como marco do inicio da sutil flexibilização da noção de fato as alterações nos critérios de verificação constantes no artigo de Carnap intitulado Testability and Meaning (1936-7), publicado originalmente na revista Philosophy of Science.
} 
O que podemos afirmar, por meio dessas considerações, é que com o critério de justificação racional assumido pelo positivismo lógico nessa época, não poderíamos dizer que certas entidades postuladas pela ciência existiam realmente. Desse modo, em função dessa adoção de critérios de aceitabilidade racional de enunciados, os positivistas lógicos possuíam um universo do discurso tal que não podiam sequer atribuir um caráter cognitivo às várias das descobertas científicas. Essas eram consideradas um modo de falar acerca do mundo natural, mas que não correspondiam realmente a ele.

Entretanto, o critério de significação cognitiva, admitido pelo positivismo lógico para resolver esse problema é que "na medida em que o sistema como um todo permite predizer nossas experiências, com maior sucesso do que poderíamos sem ele, tais predicados teóricos devem ser aceitos como 'empiricamente significativos ${ }^{28, "}$ (2008a, p. 48), o que provoca uma importante alteração na noção de fato positivista.

Putnam afirma que a linguagem, para os positivistas lógicos, caso quisesse ser cognitivamente significativa, deveria se assemelhar à linguagem que temos na física (2008a, p. 43). Porém, o próprio positivismo lógico mantêm pressupostos que não se assemelham a essa linguagem. Putnam afirma que "se for verdade que apenas podem ser aceitáveis racionalmente os enunciados verificáveis criteriosamente, esse mesmo enunciado não pode ser verificado criteriosamente" (PUTNAM, 1992, p. 147).

Portanto, o próprio pressuposto do positivismo lógico, no que diz respeito às condições de verificabilidade e aceitabilidade racional, o derroga, visto que ele não possui os pré-requisitos suficientes e necessários para que faça parte da classe de enunciados que ele mesmo afirma serem aqueles cognitivamente relevantes. É, desse modo, autorrefutante,

\footnotetext{
${ }^{28}$ Posteriormente, Carnap considerou que entidades físicas, tais como os elétrons, prótons, não são entidades que formam as teorias a partir de simples definições, mas são consideradas entidades primitivas. Segundo Putnam, essa reconsideração provocou uma revisão profunda nos critérios acima mencionados, haja vista que ao serem tomadas como primitivas, certas entidades não precisariam mais ser submetidas aos critérios. Antes, se algum termo científico abstrato pudesse assegurar-nos maior poder preditivo em uma teoria, deveríamos, assim, toma-lo como "empiricamente significativo". (PUTNAM, 2008a, p. 41). E predizer, para os positivistas lógicos, significa "deduzir sentenças de observação a partir de uma teoria" (2008a, p. 46). No caso presente, essas considerações de Putnam interessam-nos em razão da noção de fato do empirismo lógico. Embora Putnam esteja convencido de que "no critério positivista lógico revisado do significado cognitivo, é o sistema dos enunciados científicos como um todo que tem 'conteúdo factual'” $(2008$, p. 41$)$. Isso pode ser afirmado pelo que nós já expomos anteriormente. Dentro de uma teoria científica, o conjunto de enunciados articulados proporciona a capacidade de, por exemplo, prever-se um evento. Ora, se esse conjunto de enunciados, enunciados esses considerados de modo articulado, nos garante que um evento pode ocorrer, devemos concluir que o conjunto de enunciados é significativo do ponto de vista empírico. Mas essa conclusão é válida para o conjunto de enunciados, na perspectiva inter-teórica. Na perspectiva de um enunciado, considerado individualmente, a conclusão muda. Se tivermos, dentro do conjunto de enunciados de uma teoria que garante previsibilidade, um enunciado que postula a existência de um termo abstrato, poderíamos entender o conjunto de enunciados como cognitivamente relevante, pelos motivos já expostos, mas não poderíamos fazer o mesmo com o enunciado individual. Isso de deve ao fato de que, tomado individualmente, um enunciado que postula uma entidade abstrata pode estar destituída de meios de confirmação (como, por exemplo, a previsibilidade empiricamente significativa prestada pelo conjunto de enunciados) justamente em razão do seu caráter. Assim, um enunciado individual que postulasse uma entidade abstrata somente seria significativa quando interpretada no interior de uma teoria formada por enunciados empiricamente relevantes. Individualmente, um enunciado de tal espécie não teria relevância cognitiva, ou melhor, não possuiria significado. Por isso, Putnam afirma que a visão geral do conceito de fato do empirismo lógico continuou, no fundo, apesar da revisão do conceito, muito influenciada pelo empirismo clássico. Os enunciados individuais eram aceitos na linguagem científica "como meros artifícios para derivar as sentenças que enunciam realmente os fatos empíricos, a saber, as sentenças de observação" (2008a, p. 41).
} 
apesar de sua alteração na noção de fato, pois “o próprio critério dos positivistas lógicos não é (a) analítico, nem (b) testável empiricamente" (1992, p. 142).

Nos dias atuais, embora o positivismo lógico não esteja mais em voga, grande parte dos filósofos analíticos se coaduna à ideia de que a linguagem cognitivamente significativa deve seguir o modelo de uma linguagem física ${ }^{29}$. Assim, por exemplo, é muito comum exigirse na abordagem relativa a "termos psicológicos da linguagem ordinária", (2008a, p. 44-45) que esses se refiram, necessariamente, a estados cerebrais. Assim, a tristeza, como exemplo de um "termo psicológico da linguagem ordinária", deveria referir-se a um estado cerebral que lhe corresponda. Esse estado cerebral seria, destarte, a causa do estado psicológico expressa pelo termo em questão.

Diante de tal condicionamento relativo à linguagem cognitivamente relevante, é de se surpreender que possamos fazer qualquer tentativa de prestar aos valores um status de significativos. Para Putnam, a linguagem que o positivismo adota se baseia em uma adoção da noção de fato que é bastante limitada e, por isso, é incapaz de perceber que a distinção entre fato e valor não é uma dicotomia.

A dicotomia fato/valor dos positivistas lógicos foi defendida com base em um quadro cientificista estreito do que poderia ser um fato, assim como o ancestral humeano dessa distinção foi defendido com base em uma psicologia empirista estreita das ideias e das impressões (PUTNAM, 2008a, p. 45).

Ante o acima exposto, podemos colocar a crítica ao positivismo lógico e antecipar o colapso da dicotomia fato e valor nos seguintes termos: (1) a linguagem científica, preconizada pelos positivistas lógicos, é pobre, e isso deixa a maior parte do universo discursivo fora do conjunto de termos com significado. E, segundo a crítica de Putnam, pressupostos centrais do próprio positivismo lógico não podem submeter-se com sucesso à concepção criteriosa de racionalidade que lhe é própria, e que exige critérios públicos de verificabilidade que estão postos em sua compreensão da linguagem científica (2) certos termos descritivos do nosso vocabulário avaliativo implicam uma consideração aos fatos, ou seja, há, na concepção de Putnam, termos tradicionalmente avaliativos que são indesvencilháveis de um componente factual. Uma quantidade importante de termos avaliativos não pode ser fatorada em um componente puramente avaliativo e outro puramente

\footnotetext{
${ }^{29}$ Essa postura tem sido a habitual, expressando um naturalismo em filosofia, tese segundo a qual os termos com significado podem ser expressos em linguagem científica e, em última instância, em linguagem física. Repercussões a esse respeito podem ser visualizadas na interseção entre neurociência e filosofia, por exemplo.
} 
descritivo, de modo que, ainda que adotássemos uma versão de fato que esteja dependente de nossas descrições, certas descrições implicarão termos avaliativos ${ }^{30}$.

Se a dicotomia entre juízos factuais e juízos valorativos encontrava alguma legitimidade na divisão estanque entre os enunciados analíticos e os enunciados sintéticos, os argumentos em favor daquela dicotomia malogram com a demonstração de que esta última divisão deveria ser abandonada. Como demonstraremos na próxima seção, não é possível que tenhamos uma noção de fato sem que haja valores, o que Putnam chama de "imbricamento" entre fatos e valores.

\subsection{A Dicotomia entre Juízos de Fato e Juízos de Valor}

A rejeição do possível caráter cognitivo dos termos avaliativos por parte do positivismo lógico ocorre porque a sua noção de fato, herdeira do empirismo humeano, não admite, pelos seus critérios de aceitabilidade racional, a intrusão de valores. Esses critérios de aceitabilidade racional são aqueles que dizem respeito às condições estabelecidas para aceitarmos ou não um enunciado. Ainda que admitamos que a alteração da noção de fato do positivismo lógico $^{31}$ permita a inclusão de enunciados que, tomados individualmente, não são factuais, isso não resolve o problema, uma vez que a distinção analítico/sintético mostra-se colapsada. Dessa forma, as sucessivas mudanças na noção de fato pelo Positivismo Lógico, bem como o esboroamento da dicotomia analítico/sintético, deixou um vácuo no tocante aos aspectos cognitivos tanto dos fatos, quanto dos valores.

Passaremos à apresentação da posição de Putnam acerca da distinção fato/valor, que fora inflada até tornar-se uma dicotomia. Ele apresenta duas linhas argumentativas. A primeira afirma que nossas práticas cognitivas instituídas, a saber, a prática de investigação científica, pressupõem valores. A segunda linha argumentativa procurará mostrar que enunciados com valores éticos não são destituídos de conteúdo factual, ou melhor, muitos enunciados éticos pressupõem considerações acerca de fatos, o que garante que não sejam meramente convencionais. Esses dois argumentos perfazem a noção de imbricamento entre enunciados de fato e enunciados de valor, que terá como consequência aquilo que Putnam tem chamado de colapso da dicotomia fato/valor, o que deixará claro que nossos ditos enunciados factuais são avaliativos.

\footnotetext{
${ }^{30}$ A noção de que objetividade e fato devem ser igualados a descrição é rejeitada por Putnam, como veremos a seguir. ${ }^{31}$ Op. cit. 18
} 
A primeira linha argumentativa afirma que "os procedimentos através dos quais decidimos da aceitabilidade de uma teoria científica têm que ver com o fato de a teoria científica como um todo apresentar ou não certas "virtudes"” (PUTNAM, 1992, p. 173). A premissa do argumento estabelece que a "verdade", para a ciência, é um conceito puramente formal, que por si só nada diz com respeito ao conteúdo dos enunciados. Putnam declara que se quisermos saber algo acerca do conceito de "verdade" que um determinado discurso adere precisaremos esclarecer, de antemão, quais são os padrões de aceitabilidade racional que estão pressupostos em tal discurso. Isso significa dizer, do ponto de vista da verdade, que o conteúdo de um enunciado está sujeito a determinantes, que são, em última análise, os critérios utilizados no tocante à aceitabilidade racional.

Desse modo, caso a ciência almeje asseverar um enunciado qualquer, tal como "o bóson de Higgs é uma partícula subatômica", deverá fazê-lo somente se "o bóson de Higgs é uma partícula subatômica”. Se esse não for o caso, então o enunciado científico é descartado. De acordo com isso, Putnam afirma que os enunciados científicos são, na perspectiva da verdade, formais, pelo menos até esse ponto das nossas considerações, pois dizer unicamente que a ciência procura a verdade, sem apresentar as condições de aceitabilidade racional, é dizer enunciados puramente formais (1992, p. 169).

Para Putnam, as noções de verdade e aceitabilidade racional andam de mãos dadas (1992, p. 249). Com isso, a iniciativa da investigação científica é configurar uma imagem do mundo conforme certos critérios (rigorosos, metodologicamente construídos), em que a palavra "conforme" exige que esses critérios de aceitabilidade racional sejam satisfeitos na investigação própria à ciência. Putnam conclui, com relação a isso, que, caso consideremos que o objetivo da ciência é chegar a alguma espécie de verdade, "a própria verdade obtém a sua vida dos nossos critérios de aceitabilidade racional”. (1992, p. 170) E aqui chegamos a um ponto de inflexão no argumento de Putnam, segundo o qual tais critérios irão nos revelar os valores que estão implícitos na forma investigativa e metodológica da ciência.

Putnam nos afirma que há conceitos implícitos à investigação científica, tais como "coerência", "abrangência", "simplicidade", "plausibilidade", etc. Esses conceitos seriam centrais para a investigação científica, pois sem eles não poderíamos formar uma teoria qualquer, muito menos cotejar teorias para sabermos qual é a melhor, ou que teoria é mais apropriada para explicar determinado conjunto de eventos, de modo que funcionam como os denominados critérios de aceitabilidade. Em uma palavra, os conceitos trazidos aqui são condições para que o empreendimento científico possa ser consistente e significativo, e sem 
eles a tarefa científica estaria malograda de antemão. Putnam diz que esses conceitos são valores epistêmicos.

De acordo com essa afirmação, pretendemos nos aproximar da verdade do mundo fazendo uso das teorias que escolhemos, e essas teorias possuem os valores, já listados, de "coerência”, "preditibilidade", por exemplo. O que Putnam alega é que esses valores são componentes através dos quais nós conseguimos obter nossas descrições do mundo. Podemos compreender essa alegação da seguinte maneira: nossas descrições do mundo estão comprometidas com os valores, donde concluiremos, por um lado, que sem os valores não conseguiríamos formular uma visão de mundo, de modo que precisamos deles para sermos exitosos (mesmo) em nossas pretensões cognitivas mais sofisticadas, como é o caso das teorias científicas (PUTNAM, 2008a, p.52); e, por outro lado, concluiremos que uma justificação externa desses mesmos valores está fora da alçada de confirmação pela via tradicional, segundo a qual deveríamos poder verificar sua objetividade por meio de uma correspondência com uma descrição correta da realidade.

Essa última afirmação acerca da descrição correta da realidade nos remete à posição do realismo ${ }^{32}$ tradicional, assim denominada por Putnam, para o qual deve haver uma correspondência entre a realidade e as nossas tentativas de representar essa realidade tal como ela é. Desse modo, Putnam nos diz que:

\begin{abstract}
...se o realismo metafísico (tradicional) estiver certo, e se se pudesse ver o objetivo da ciência simplesmente como tentar conseguir que o nosso mundo nocional "correspondesse" ao mundo em si, então podia alegar-se que estamos interessados na coerência, abrangência, simplicidade funcional e eficácia instrumental apenas porque estas são instrumentos com o fim de realiza esta "correspondência". Mas a noção de correspondência transcendental e o mundo é em si um contrassenso. (PUTNAM, 1992, p. 174).
\end{abstract}

Putnam programa, a partir dessa consideração, encetar uma crítica ao realismo tradicional. Caso não o fizermos, teremos a permanência de problemas que gostaríamos de evitar, quais sejam, a noção de que os conceitos implícitos à investigação científica, os valores epistêmicos, são meramente convencionais, não sendo necessários senão para atender os nossos desideratos de correspondência à realidade unívoca; e a convicção de que

\footnotetext{
${ }^{32}$ Segundo Simon Blackburn, "Um realista sobre um assunto A pode sustentar (I) que os tipos de coisas descritas por A existem; (II) que sua existência é independentes de nós, ou que não são objetos produzidos pela nossas mente, linguagem ou esquema conceitual; (III) que as afirmação que fazemos em A não são redutíveis a outros tipos de afirmações eu possam afinal revelar ser acerca de outra coisa que não A; (IV) que as afirmações que fazemos em A têm condições de verdade, constituindo descrições inequívocas de aspectos do mundo, sendo verdadeiras ou falsas em função dos fatos do mundo; (V) que conseguimos obter verdades acerca de A, e que é apropriado acreditar completamente no que afirmamos em A”. (BLACKBURN, 1997, p. 335)
} 
"objetividade" é o mesmo que correspondência a objetos. Isso excluiria, de uma vez por todas, a tentativa de compreender os valores em seu aspecto cognitivo.

Destarte, para que possamos conferir aos enunciados avaliativos o caráter de cognitivos, devemos empreender uma reformulação à noção tradicional de objetividade, que é arrendatária dos pressupostos do realismo tradicional. Ao criticar o realismo tradicional, Putnam irá nos fornecer instrumentos para alterarmos a noção de objetividade. E, em não sendo objetivo somente o que é factual, como já tínhamos visto e criticado por outra via, depois das considerações sobre o realismo tradicional, a noção de fato surge como interdependente de nossa linguagem, que é, a uma só vez, descritiva e avaliativa. Comecemos, então, a crítica de Putnam ao realismo tradicional.

A crítica de Putnam ao realismo tradicional inicia-se com a identificação de que uma das suas questões problemáticas consiste em pensar-se, segundo suas próprias palavras, "que existe uma totalidade de Formas, ou Universais ou 'propriedades', estabelecida de uma vez por todas, e de que todos os significados possíveis de uma palavra correspondem a uma dessas formas ou Universais ou propriedades" (2008c, p. 19). Putnam observa que o problema aqui patenteado diz respeito ao significado. Pensa-se, em geral, que o significado das palavras designa uma propriedade a qual estas palavras referem-se, de modo que uma palavra tem como função apreender o mundo tal como ele é, com suas propriedades intrínsecas.

Putnam supõe o exemplo das espécies naturais, salientando que todas as amostras de ouro puro, bem como os objetos forjados com ouro puro, possuem em comum a propriedade de constituírem-se de isótopos do elemento atômico de número 79. Entretanto, Putnam está convencido de que a palavra ouro não é sinônima de "elemento atômico de número 79". Isso ocorre porque o significado cotidiano da palavra 'ouro' não pode ser definido como uma propriedade ou conjuntos de propriedades. Wittgenstein ${ }^{33}$ corrobora a ideia de que fazemos uso de vasta gama de palavras com respeito às quais não existem propriedades comuns a todos os objetos a que estas palavras se aplicam com correção.

Desse modo, estabelece-se uma visão metafísica segundo a qual a realidade é apresentada como "um conjunto fixo de objetos 'independentes da linguagem' e uma ‘relação' fixa entre os termos e suas extensões” (PUTNAM, 1999, p. 102). Putnam nos traz a reflexão de que os objetos não são independentes da linguagem, ao mesmo tempo em que afirma que a imagem de mundo "não é o produto da nossa vontade - nem das nossas disposições para falar de determinadas maneiras" (1999, p. 103). Com isso, Putnam está a

\footnotetext{
${ }^{33}$ Ver a obra Investigações Filosóficas, de Wittgenstein.
} 
dizer que a linguagem exerce a função de elaborar um vocabulário que possa estabelecer uma conexão com o mundo, vocabulário que pode ser melhor elaborado, com o fim de referir-se melhor do que antes aos objetos.

Podemos dizer que Putnam quer enfatizar a importância da linguagem em todo o trâmite da tarefa de representar o mundo. Na visão da metafísica tradicional, julga-se que a linguagem é impassível do ponto de vista da representação. Isso quer dizer que, frente ao mundo, a tarefa linguística consiste em estabelecer a função de designadora, sendo esta linguagem, porém, neutra. A neutralidade linguística dos termos que compõem a realidade implica uma imagem de mundo em que o instrumental fornecido pela linguagem serve meramente como expressão verbal de nossas impressões e representações.

Outra questão suscitada pela crítica ao mencionado tipo de realismo tradicional "é o pressuposto confortável de que há uma totalidade definida de objetos que pode ser classificada, bem como uma totalidade definida de todas as propriedades" (2008, p.19). A crítica de Putnam à definição peremptória do universo de objetos que podem ser referidos, e a coleção fixa de propriedades, pode levantar a falsa objeção segundo a qual o mundo é totalmente construído pelos indivíduos ${ }^{34}$. Todavia, Putnam observa que nossas pretensões de conhecimento se dirigem a uma realidade em geral independente dos indivíduos, ou melhor, dos falantes.

Embora Putnam corrobore a ideia de que há uma realidade independente dos falantes, ele está seguro de que "a reflexão sobre a experiência humana sugere que nem a forma de todas as alegações de conhecimento nem os modos pelos quais elas são responsáveis perante a realidade são estabelecidos de antemão e de uma vez por todas" (2008, p. 20). Pode-se afirmar, portanto, que apesar de Putnam supor uma realidade em geral independente da mente, não há, com relação ao projeto humano acerca do conhecimento, uma independência concernente ao modo e à forma de nossas alegações cognitivas. Se isto não estiver correto, podemos estabelecer a noção rejeitada por Putnam, segundo a qual existe um número delimitado de propriedades que devemos simplesmente "descortinar", “descobrir" e, feito isso, usarmos tais propriedade para denotar os objetos constantes na realidade, que por sua vez são também delimitados e fixos.

\footnotetext{
${ }^{34}$ Para maiores elucidações a essas críticas feitas a Putnam, ver BOGHOSSIAN, Paul. Medo do conhecimento: contra o relativismo e o construtivismo, 2012, pp. 61-63. São Paulo: editora senac. Esta contestação de Boghossian toma como exemplo a noção de descrição da realidade constante na obra de Putnam Realismo de Rosto Humano, capítulo 6, intitulado Verdade e Convenção. Falar-se-á a respeito dessas críticas quando comentarmos o caráter não relativista do realismo interno.
} 
Mas a que tipo de objetos o realista tradicional se refere? Putnam afirma que "As formas tradicionais de realismo estão comprometidas com a alegação de que faz sentido falar de uma totalidade estabelecida de todos os 'objetos' a que nossas proposições podem referirse" (2008, p.20). Embora isso seja dito, a pergunta continua em aberto. Putnam interroga se um evento histórico, como a Segunda Grande Guerra, é um objeto. Do mesmo modo, o céu é um objeto? Ou a imagem que percebemos no espelho é um objeto? Teríamos que atentar para os critérios estabelecidos pelo metafísico tradicional e, assim, identificarmos o que seria um típico objeto nessa ontologia.

Putnam nos diz que o problema sobre objetos está posto antes mesmos de supormos a existência de entidades como as que postulamos acima, dado o antigo critério de individualidade de um objeto, qual seja, o de que suas partes acompanham o movimento do objeto quando este se deslocar. Putnam obtempera que há objetos de existência inquestionável que infringem este critério e afirma: "tenho em casa uma lamparina que viola este critério; a sombra diminui sempre que a lamparina se desloca! Será que a lamparina neste caso não é um objeto?" (2008c, p. 21).

A resposta pode estar na noção de soma mereológica, na qual os objetos são, eles próprios, aditamentos de partes de outros objetos. Putnam supõe que a soma mereológica poderia solucionar o problema da lamparina, explicando o porquê de ela ser um objeto. Porém, ele destaca que as consequências podem ser fortes e os resultados muito caros: "Se a 'soma' de quaisquer dois (ou mais) objetos for um objeto; se houver até um 'objeto' formado pela minha orelha esquerda e o nariz do leitor, então existe de fato um objeto equivalente à soma mereológica do corpo da lamparina e da sombra" (2008c, p. 21).

Este exemplo levantado por somas mereológicas suscita uma modificação das concepções tradicionais acerca dos objetos e, mais ainda, da alegação de conhecimento possível que deles temos, e de que suas propriedades possíveis são passíveis de mudanças centrais. Segundo Putnam:

\footnotetext{
O realista tradicional parte do princípio de que os nomes gerais correspondem, de maneira mais ou menos unívoca, a várias "propriedade" de "objetos", em algum sentido de "propriedade" e em algum sentido de "objeto" estabelecidos de uma vez por todas, e de que as alegações de conhecimento são simplesmente alegações sobre a distribuição dessas "propriedades nesses “objetos” (PUTNAM, 2008, p.22)
}

Putnam considera que o realista tradicional está completamente certo em um ponto: ele tem a acertada convicção de que a realidade é independente, e que as descrições que dela 
fazemos e chamamos de 'mundo' devem manter uma espécie de responsabilidade cognitiva. Em que pese essa imagem, não devemos a ela conectar a noção de que existe uma descrição ou descrições que estão postas de uma vez por todas, todas elas possíveis, e com as quais devemos nos referir, necessariamente, a essa mesma realidade. A afirmação seguinte de Putnam é que com esta imagem das descrições que a metafísica tradicional preconiza perdemos o mais importante e verdadeiro aporte do pragmatismo: “o de que a 'descrição' nunca é uma mera cópia e de que estamos sempre criando novas maneiras de a linguagem poder ser responsável perante a realidade ${ }^{35 ",}(2008$ c, p. 22).

Embora essa contribuição possa ser tomada de vários modos, tal como o próprio James $^{36}$ e Putnam o fizeram, esse diz que não estamos habilitados a concluir o mesmo que aquele, a saber, que nós criamos, em parte, o mundo. Ora, para Putnam a existência de uma realidade independente de nós é algo do qual não podemos duvidar a sério, e o simples fato de assumir isso já o coloca na categoria daqueles que aderem ao realismo. A característica agora enfatizada é a recusa da chamada ingenuidade do realismo tradicional, segundo a qual existe uma totalidade fixa de objetos e propriedades em cuja relação descobrimos as propriedade para denotar os objetos.

O que motiva esta dispensa da ingenuidade do realismo tradicional é a compreensão de que nossa linguagem e seu evidente uso estão colocados desde sempre, e que não devemos transigir com a ideia de que as propriedades, expressadas pelos conceitos, modos de referências, formas de descrições, apresentação de significados, etc., são imutáveis. Putnam esclarece sua posição da seguinte maneira:

A ideia de que nossas palavras e nossa vida são constrangidas por uma realidade exterior a nós desempenha um importante papel em nossa vida e deve ser respeitada. A fonte de confusão reside no erro filosófico vulgar de se supor que o termo realidade tem de referirse a uma única supercoisa, em vez de considerar as formas como renegociamos incessantemente - e somos forçados a renegociar - nossa noção de realidade à medida que nossa linguagem e nossa vida se desenvolvem. (PUTNAM, 2008, 23)

A esta crítica segue-se naturalmente o que Putnam nos trará, a saber, a constatação da ininteligibilidade da afirmação, feita pelo realista tradicional, de que há "uma nítida linha divisória entre as propriedades que 'descobrimos' no mundo e as que 'projetamos' no mundo" (2008, p. 35). Esta crítica é moderadamente explícita no que Habermas tentou elucidar

\footnotetext{
${ }^{35}$ Essa consideração é, segundo Putnam, inspirada em William James.

${ }^{36}$ Ver o texto $O$ Empirismo Radical, de William James. Esse texto está relacionado na obra Pragmatismo e textos selecionados, arrolado na bibliografia desse trabalho.
} 
quando conclama a metáfora de que há um 'livro da natureza', ensejada pelas suas considerações sobre o realismo pós-metafísico ${ }^{37}$.

Isso significa que a realidade não possui termos próprios que podemos captar por meio de um processo de apreensão sígnico misterioso e, destarte, configurar uma noção de mundo que esteja a ela adequadamente acoplada em um sentido apenas em segunda instância linguístico. Seria só em segunda instância linguístico, pois o processo de captura da realidade “tal como ela é” não se daria à nossa compreensão por meio linguístico.

Este é o problema que está pressuposto na forma de acoplagem (o modo como a linguagem se conecta ao mundo) do realismo tradicional decorrente do que Putnam diz acima, qual seja, o de passarmos da apreensão das propriedades extralinguísticas da realidade para a conceituação semântica do mundo. O que pode ser evidenciado na passagem da percepção da realidade para a sua intelecção (linguística). A ininteligibilidade da "linha divisória", indistinta, não nos habilita a afirmar que o mundo não possui propriedades extrínsecas à mente humana. Esta conclusão seria uma extrapolação com a qual Putnam não se coaduna, pois sua consequência imediata é a recusa da existência de uma realidade independente de nossas descrições e conceituações.

O que a noção de ininteligibilidade da afirmação da linha divisória, com relação às propriedades "descobertas" e às propriedades "projetadas", enseja concluir, é que subjaz à interpretação da classe dessas propriedades o uso linguístico que nós criamos para nos referir a ambas. Se não há uma linguagem factual da natureza e, portanto, ela não possui termos intrínsecos com os quais devemos a ela nos referir, torna-se azado sugerir uma linguagem capaz de fazê-lo, linguagem esta que é consignada pelo uso que dela fazemos ${ }^{38}$.

Pode-se dizer, em uníssono com Putnam, que o que liga a crítica do realismo tradicional à reformulação do conceito de fato é a limitação que as tradicionais dicotomias "juízos de fato versus juízos de valor" e "verdades de fato versus verdades analíticas" promovem. É justamente a tomada de posição do realismo tradicional que irá contaminar o conceito de fato, fazendo deste um conceito que, em sua versão moderna, somente refere-se a objetos que podem ser percebidos pelos sentidos, deixando os valores relegados à subjetividade plena.

\footnotetext{
${ }^{37}$ Antecipando o pensamento que Habermas cita de Putnam, "não existe tal coisa como a linguagem própria do mundo". A citação completa está no capítulo 3 deste trabalho, na página 50.

${ }^{38}$ Não haver uma linguagem própria à natureza, com a qual poderíamos nos referir a ela perfeitamente, caso conseguíssemos fazer uso de tal linguagem, não nos coloca na difícil situação na qual não podemos nos referir com precisão à realidade: apenas teremos, para descrever e denotar as propriedades da natureza, que fazer uso de uma terminologia que não é intrínseca à realidade, mas a qual ela se refere e por ela é motivada efetivamente. Podemos afirmar que os termos que usamos para nos referir à natureza lhe são extrínsecos, embora se refiram a ela, sempre com maior ou menor grau de precisão, e por ela são motivados. Por isso, a nós, na acepção linguística, cabe "renegociar" nossos termos de referência (PUTNAM, 2008c, p. 23).
} 
Segundo Putnam, estas dicotomias estanques "corromperam nosso pensamento, tanto no raciocínio ético como na descrição do mundo, principalmente, por impedir-nos de ver como a avaliação e a descrição estão interconectadas e são interdependentes" (2008a, p. 15). A limitação se sobrepõe ao conteúdo filosófico e torna-se consagrada. O esforço de Putnam em buscar um novo tipo de realismo que se preste a uma explicação heterodoxa de como nos relacionamos com o mundo nos é importante porque ela necessariamente reformula aspectos da metafísica tradicional, lançando-lhe as bases para uma contestação do conceito de objetividade que se consolidou na história da filosofia, desde a filosofia moderna ${ }^{39}$.

Passemos à análise sobre o pressuposto último do realismo tradicional criticado por Putnam, a saber, que há "uma relação fixa de 'correspondência' em termos da qual se supõe que a verdade seja definida" (2008c, p.35). Putnam nos lembra, após mencionar o pressuposto do realismo, que sua rejeição está caracterizada pela ininteligibilidade dessa afirmação. Este pressuposto parece resumir, de algum modo, todos os pressupostos anteriormente mencionados, cujos apanágios são: a fixidez das formas predicativas da linguagem, e a consequente fixidez das interações entre os aspectos da realidade e a mente; e a possibilidade de nos referirmos aos objetos do mundo não só de modo adequado, mas de modo unívoco, a que se segue uma capacidade de podermos fazer corresponder nossos enunciados linguísticos a tais objetos, desembocando em uma teoria da verdade por correspondência unívoca.

A rejeição, ou declaração de ininteligibilidade dos pressupostos da metafísica do realismo tradicional é, necessariamente, uma recusa da noção de verdade que destes pressupostos decorrem. Se considerarmos que a noção de fato tem estado intimamente relacionada com ao menos um desses pressupostos, estaremos afirmando que o 'fato' conectase àquilo que no realismo tradicional chama-se objeto. Apesar de toda a discussão em torno do que é um objeto, sabemos que na história da filosofia há uma relação de proximidade indesvencilhável entre fato e objeto, pois só poderia ser factual o que é objetual. Ao contrário, o subjetivo não poderia ser um fato. A crítica de Putnam é dirigida ao realismo tradicional e à absorção de algumas das decorrências desse realismo pelo empirismo humeano - como a

\footnotetext{
${ }^{39}$ A dificuldade que se tem ao tentar conectar as questões clássicas do realismo tradicional a uma análise de sua influência nas questões de valor (ético) está posta pela falta de acuidade que temos, pois não damos importância suficiente àquilo que as une - trata-se de uma polarização, também estanque, entre objetividade e subjetividade. Uma tomada de posição inovadora com relação ao realismo implicará outro ponto de vista concernente à objetividade, pois teremos que atenuar, no caso específico de Putnam, a linha entre a objetividade e a subjetividade para darmos conta dos aspectos perceptivos com relação ao mundo ou, em outras palavras, para conseguirmos explicar a relação entre a mente e o mundo. Está patente que nos interessa enfatizar os tópicos que poderão nos fornecer o instrumental necessário para seguir o argumento de Putnam, e que a linguagem exerce um papel fundamental que estará no centro da compreensão putnamiana da verdade. Temos, neste momento, a sua crítica ao realismo tradicional.
} 
noção tradicional de fato $^{40}$ e a representação dos objetos como cópia, proporcionada a partir do aparato sensorial.

Como vimos, para localizar o lugar dos valores e dos fatos na dicotomia tivemos que reorientar essas noções. Putnam nos apresenta uma crítica ao realismo tradicional, mas não nega que possamos almejar um tipo de adequação ao mundo empírico:

... usamos os nossos critérios de aceitabilidade racional para construir um quadro teórico do "mundo empírico", e então à medida que essa imagem se desenvolve revemos os nossos próprios critérios de aceitabilidade racional à luz desse quadro e assim por diante, e assim por diante sempre (PUTNAM, 1992, p. 174).

Podemos perceber que um dos resultados da crítica de Putnam ao realismo tradicional é que nossa linguagem pode ser indefinidamente melhorada para nos referirmos ao mundo empírico, mundo esse externo e independente de nós. Embora essa independência (enquanto existência do mundo externa à mente humana) seja algo patente, a respeito do qual Putnam não contrapõe nenhum argumento, ele sublinha o papel da linguagem no mundo real. Desse modo, o mundo real, formado pelos objetos aos quais nos referimos, é moldado segundo nossos critérios de aceitabilidade racional, propostos por nossa linguagem.

A conclusão a que Putnam chega é a seguinte: nosso vocabulário é como que constrangido pelo mundo empírico, e não é uma criação aleatória e unilateral, pois o mundo participa da formação desse vocabulário. Porém, nosso enquadramento do mundo real não é indiferente e impassível a esse mesmo vocabulário e, uma vez que os nossos valores são a lente através das quais nós podemos visualizá-lo, esse enquadramento do mundo real depende dos nossos valores. Em suma, o mundo externo à nossa mente não depende de nossas considerações concernentes a ele para existir, mas o mundo, com seus objetos, depende de nossos valores para ser formado, haja vista que não existe uma linguagem independente de nós no mundo.

Ademais, Putnam declara que ao menos alguns dos valores epistêmicos têm que ser objetivos. Ele argumenta que aceitar racionalmente um determinado enunciado depende do pano de fundo constituído por valores epistêmicos, pois os enunciados cognitivos não podem ser formulados, significativamente, sem a adesão a termos valorativos (PUTNAM, 1992, p. 175). O imbricamento entre as noções de fato e valor nega que os enunciados factuais possam ser neutros. Afinal, a tese do imbricamento entre as noções de fato e valor repousa na revisão dos pressupostos do realismo tradicional, de modo que seria despropositado afirmar uma

${ }^{40}$ Corroborada, posteriormente, por características típicas do empirismo, como, por exemplo, os dados dos sentidos. 
linguagem do mundo inteiramente factual, independente de nossos usos e aplicações conceituais (PUTNAM, 2008a, p. 147).

Se aceitarmos a crítica ao realismo tradicional em pelo menos uma de suas considerações, o teremos suficientemente fragilizado para podermos afirmar, depois de tudo exposto, que o modo de falarmos sobre a realidade exterior depende de conceitos por nós aplicados a ela. Não obstante, esses conceitos são suscitados pela pressão dessa realidade exterior que, assim, corrobora sua formação, e, portanto, não são meramente casuais ou convencionais. $\mathrm{O}$ fato de nossos usos e aplicações de conceitos se referirem a uma realidade exterior independente de nós quer dizer, a uma só vez, que não há algo como propriedades de objetos independentes de nossa linguagem (2008a, p. 23); e também que nossa linguagem conceitual refere-se a características dessa realidade exterior (PUTNAM, 1992, p. 176).

De acordo com isso, podemos dizer que termos avaliativos como "coerente", "simples", etc., não são destituídos de uma aplicação que se relaciona com a realidade, visto que no tocante à aplicação desses termos há uma importante "adequação" a essa realidade mesma. Aplicar um conceito é, dessa maneira, adequá-lo àquilo que é referido não unicamente de modo individual (o que culminaria em um subjetivismo de tipo solipsista), mas também de modo reconhecível, o que significa que a aplicação deve poder ser compreendida por outros usuários da linguagem, e não tão-somente pelo indivíduo que realiza (ou aciona) a aplicação imediata (1992, pp. 158-159).

Portanto, a tarefa de aplicar um termo avaliativo à realidade não é uma tarefa apenas subjetiva, pois, caso o fosse, poderíamos dizer que uma teoria qualquer é "coerente, para o indivíduo $x$ ” e "não é coerente, para o indivíduo $y$ ”. Porém, isso contraria a própria natureza do termo "coerente", pois há nesse termo uma reinvindicação que não é meramente a possibilidade de uso privado, mas, antes, a reinvindicação de uma aplicação conceitual que possa ser reconhecida por indivíduos em seu caráter intersubjetivo.

Concluiremos, assim, que crítica ao realismo tradicional nos conduz à percepção do quão importante e relevante são para a constituição da noção de fato os critérios de aceitabilidade racional. Os valores são, eles mesmos, partes necessárias sem as quais não teríamos um mundo de fatos (1992, p. 249). E esses valores são o centro da noção da aceitabilidade racional, justamente o que nos habilita dizer de um enunciado se ele é verdadeiro ou falso. 


\subsubsection{Conceitos Éticos Espessos}

Putnam diz que um problema decorrente da dicotomia entre enunciados factuais e avaliativos é considerar separadas, de forma estanque, a nossa linguagem descritiva de nossa linguagem usual, que objetiva elogiar ou censurar (PUTNAM, 1992, 178). Por isso, habitualmente se tem suposto que há um tipo de linguagem cotidiana, que possui um vocabulário descritivo, que se refere somente a um mundo formado por fatos, e um vocabulário com termos propriamente avaliativos, do qual nos utilizamos quando queremos prescrever ou incentivar um comportamento, conquanto seja não cognitivo. Ambos os tipos de vocabulários seriam, nessa configuração, independentes entre si.

Desse modo, os conceitos éticos fariam parte do vocabulário avaliativo, pois tradicionalmente tomamos conceitos éticos como destituídos de racionalidade (em seu aspecto cognitivo, algo que subjaz à dicotomia fato/valor). Entretanto, a tarefa a que Putnam se propõe tenciona revelar o caráter do imbricamento do fato e do valor nas questões éticas, expondo, assim, a generalidade do colapso da dicotomia ora tratada. Os conceitos éticos abstratos, também chamados de tênues, são aqueles que utilizamos para dizer de uma ação se ela é correta ou boa. No caso, "correto" e "bom" são conceitos éticos abstratos (PUTNAM, 1999a, p. 240).

A característica de tais conceitos é não possuírem um componente descritivo independente das ações. Assim, o emprego dos termos éticos abstratos está relacionado aos enunciados como valores éticos, como, por exemplo, na frase “"Não seja indelicado' é uma prescrição boa". Nesse exemplo, o termo ético abstrato não possui um componente descritivo independente, antes, depende do que o termo "indelicado" quer significar. Só a partir de uma consideração ao componente descritivo intrínseco ao termo "indelicado" é que o conceito ético abstrato pode ser aplicado, o que revela que sua aplicação é feita em segunda instância, pois depende do conteúdo do termo em questão.

Segundo Putnam, é justamente a classe de termos éticos exemplificada por "indelicado" que torna evidente o imbricamento entre juízos de fato e juízos de valor. Isso ocorre porque não podemos "fatorar", ou seja, distinguir de modo estanque os componentes descritivo e avaliativo dessa classe de termos éticos (PUTNAM, 1992, p. 252). Essa classe de termos éticos foi denominada conceitos éticos espessos (ou densos). A nomenclatura se deve ao fato de que em certos casos os valores são descrições e, portanto, ao invés de valores e descrições contrastarem, eles se sobrepõem e coincidem (PUTNAM, 2004, p. 74). 
A forma mais direta de explicar os conceitos éticos espessos é com a colocação de um exemplo em que é patenteado que os dois componentes estão imbricados. Segundo esse exemplo, quando se diz que determinado indivíduo é cruel temos que (1) há uma importante tentativa de caracterização de um comportamento e (2) tal comportamento está, quando assim caracterizado, expondo traços do indivíduo que nos fornecem elementos avaliativos, que não podem ser excetuados do conteúdo descritivo do termo.

Desse modo, seria curioso afirmar que um indivíduo é cruel e bondoso, ao mesmo tempo, pois as características descritivas para um indivíduo cruel presumem considerações avaliativas, de tal modo inerentes, que seria impossível acrescentar-lhe a virtude da bondade. Igualmente, pode-se afirmar que os componentes descritivos e avaliativos, no tocante aos conceitos éticos espessos, são indesvencilháveis, por força de a descrição ser interdependente do componente avaliativo. Em sendo a descrição interdependente do componente avaliativo, e ante todo o exposto no capítulo, pode-se concluir que a tentativa de consolidar a dicotomia fato/valor utilizando a estratégia da tese dos dois componentes é malograda.

Segundo essa tese, não há uma interdependência dos componentes descritivo e avaliativo, e cada um deles está desconectado do outro. Essa perspectiva malogra porque seu sucesso depende de uma noção de fato que foi amplamente criticada nesse trabalho, qual seja, a noção segundo a qual somente fatos podem ser objetivamente predicados, produzindo o resultado de que a descrição é uma característica de objetos aos quais os predicados podem ser referidos. Quando superamos o realismo tradicional, a noção de objetividade é reformulada, uma vez que os objetos não estão acabados de modo peremptório, o que gera a consequência de termos de participar do processo de formação daquilo que prestará aos enunciados seu caráter cognitivo.

O imbricamento, como se pode perceber, irá relacionar de modo próximo e interdependente os componentes factuais e avaliativos. É esse expediente que irá prestar aos enunciados éticos a cognitividade aqui almejada, haja vista a mudança na noção de fato ser uma consequência das críticas lançadas. Para o estabelecimento do fato a descrição é insuficiente e precária. O componente avaliativo revelou-se, como demonstramos, precípuo para que o fato possa ser considerado. Temos, desse modo, a objetividade por meio da cognitividade alcançada, e podemos, então falar quanto a um enunciado ético se ele é verdadeiro ou falso.

No próximo capítulo iremos continuar com a exposição das principais ideias de Putnam, dessa vez por meio do debate encetado por ele e Jürgen Habermas. Nesse debate, 
Putnam utiliza-se de vários dos recursos ora discutidos, como, por exemplo, os conceitos éticos espessos, para apresentar uma solução ao problema da cognitividade dos enunciados normativos, procurando mostrar, novamente, que as normas pressupõem valores, e que se os valores forem subjetivos, as normas também o serão. Essa posição é contrária à que Habermas defende, pois, segundo esse, os valores não são objetivos, ao passo que as normas podem reivindicar objetividade.

Para estabelecer seu ponto, Putnam faz uma crítica à teoria do discurso de Habermas. Por isso, parecerá que ele não eleva a crítica a Habermas a um patamar erudito, mas instrumentaliza, de certo modo, este debate. Suas considerações podem, de fato, ser contestadas pelos especialistas. Porém, o que este trabalho visa com a apresentação do debate é a revelar alguns dos desdobramentos da posição putnamiana, ressaltados no bojo desse debate, e Habermas, nesse percurso, funciona como um interlocutor privilegiado. 


\section{CAPÍTULO III: A APRESENTAÇÃO DA POSIÇÃO DE PUTNAM POR MEIO DO DEBATE}

\subsection{Acerca do debate entre Hilary Putnam e Jürgen Habermas}

O debate entre Putnam e Habermas tem seu ponto de partida em uma palestra pronunciada por aquele filósofo em homenagem aos setenta anos deste, em 1999, em um congresso na universidade de Frankfurt (VEGA ENCABO \& GIL MARTíN, 2008, p. 9). Putnam manifesta sua discordância com relação à distinção habermasiana entre os conceitos "norma" e "valor". Em seguida Habermas retorque a Putnam em uma palestra na qual mostra, em vários tópicos distintos, muitas convergências para com as reflexões que Putnam tem feito ao longo dos últimos anos. Porém, no final de sua palestra, Habermas procura exprimir uma crítica ao afirmar que Putnam usa o mesmo tipo de validade para enunciados empíricos e enunciados valorativos. A recusa dessa crítica é o cerne da réplica de Putnam e, feito isso, a presente rodada do debate se encerra.

As três apresentações foram compiladas e apresentadas como o primeiro ciclo de palestra sobre um tema que ganhou o interesse de ambos os filósofos envolvidos, o que deu azo a um novo encontro que ainda não foi publicado ${ }^{41}$. Dessa forma, apesar de as palestras aqui referidas não serem a última palavra que estes filósofos têm a dizer sobre o tema, este autor considera que são vários os esclarecimentos e questionamentos que elas aduzem. Apesar da ocasião honorífica em que o congresso se dá, no que tange a essa rodada inicial do debate, a ênfase recai sobre a filosofia de Putnam, haja vista que das três palestras duas são pronunciadas por ele, e mesmo na palestra de Habermas é a filosofia de Putnam que está em evidência.

Nesse sentido, o presente capítulo tem como objetivo apresentar a posição de Putnam por meio de seu debate com Habermas, buscando responder as seguintes perguntas: No que consiste o debate? Qual é a posição de Putnam? Veremos que o debate gira em torno de um problema que está articulado ao conceito de objetividade, e que Putnam utiliza-se de sua abordagem vista no capítulo anterior, a qual será devidamente aditada aqui.

\footnotetext{
${ }^{41}{ }^{41}$ Uma nova rodada de debates ocorreu em novembro de 2002 na Northwestern University, dos Estados Unidos da América, com o título "Norms, Facts and Values". Aguarda-se sua publicação (NAVIA, 2012, p. 12).
} 
Todos esses questionamentos são fragmentos que objetivam, quando respondidos, reconstituir o posicionamento putnamiano no que concerne à objetividade dos valores. Depois da recusa peremptória à metafísica tradicional, a tentativa de Putnam visa a nos assegurar um conceito de objetividade. Evidentemente, o ponto de partida deverá ser outro, e poderá soar heteredoxo.

Antes de expor o debate propriamente, iremos falar em qual cenário a discussão ocorre. Há muitas concordâncias entre os dois filósofos, pois ambos fixam suas posições no que tem sido chamado de virada pragmatista da linguagem. Falaremos desse pano de fundo compartilhado e das características da virada pragmatista na medida em que ela for importante para a compreensão da posição de Putnam que, como já foi dito, será a posição enfatizada neste trabalho.

\subsubsection{O que há de comum nas posições distintas do debate?}

A posição inicial de ambos os debatedores dá-se a partir da recusa dos pressupostos estabelecidos historicamente pela metafísica tradicional. Vimos no capítulo dois quais são as principais objeções que Putnam faz aos apanágios que são tipicamente compreendidos como sendo os formadores da concepção metafísica.

Segundo Ricardo Navia, os filósofos (1) "rechaçam as posições não-cognitivistas, a partir de argumentos de tipo pragmatista"; (2) "se opõem a equiparação da objetividade dos enunciados normativos com os enunciados empíricos e científicos"; (3) Vão conceber que a possibilidade de objetividade dos enunciados valorativos possa estar baseada não na contrastação com fatos independentes", mas, antes, possa estar baseada "em certo tipo de razões"; (4) “Ambos rechaçam uma ontologia realista que postule a existência de entidades ou qualidades não naturais que se supõe que seriam captáveis por algum tipo de especial de faculdade (intuição axiológica)", sendo que essa faculdade é o que vai nos permitir avaliar a correção e a incorreção dos enunciados valorativos. E, ponto derradeiro elencado por Navia, (5) A recusa de uma "ontologia deflacionária de certo realismo redutivo que sustenta que as propriedade a que se referem nossas linguagens normativas não são propriedades ou conceitos com um estatuto próprio", mas que são "propriedades naturais e, portanto, os enunciados são redutíveis a uma linguagem naturalista" (NAVIA, 2012, pp. 14-15).

Essas supracitadas linhas mestras apresentam a toada na qual o debate se desenvolve. Em primeiro lugar a substituição da metafísica tradicional (e todas as suas consequências) por 
uma perspectiva pragmatista. Em um ambiente pragmatista, o tratamento a certos temas recebe uma abordagem inovadora, por força das características fundamentais da pragmática.

A pragmática ${ }^{42}$ é uma área da filosofia da linguagem que fundamenta o significado dos termos envolvidos em contextos de uso linguístico. O usuário da linguagem vale-se dela em determinado contexto, e é a partir da relação entre (i) os termos constantes de um vocabulário, (ii) o usuário da linguagem, e (iii) o contexto linguístico que se pode afirmar algo sobre os enunciados. Essa é a estrutura linguística básica por meio da qual aos enunciados pode ser conferido significado.

O usuário linguístico, nesse caso, é o conjunto de usuários de linguagem, e não exatamente um único indivíduo. Como afirma Navia,

\begin{abstract}
... as condições transcendentais para o conhecimento dos objetos não vêm dadas por estruturas subjetivas, mas pela primazia das práticas dos seres humanos capazes de ação e de linguagem"..."As condições de possibilidade já não se encarnam em um sujeito atemporal e imutável, mas em práticas linguísticas e em formas de vida socioculturais" (NAVIA, 2012, p. 15).
\end{abstract}

A situação originária de usuário de uma linguagem presume um estado em que a linguagem pode significar algo em uma comunicação interacional entre aqueles que aplicam o vocabulário com vistas à compreensão mútua. A linguagem, nesse caso, é uma forma de ação, e não exatamente uma simples descrição da realidade.

$\mathrm{Na}$ acepção clássica, a função designativa é a principal finalidade da linguagem. Essa função é acessória de um desiderato objetivado pela metafísica tradicional, qual seja, alcançar o conhecimento verdadeiro que está fundamentado na "essência imutável das coisas, o que, precisamente, é depois comunicado pela linguagem" (DE OLIVEIRA, 2006, p. 121). A linguagem, portanto, estabelece um vínculo com os objetos do mundo na medida em que fornece uma descrição do que eles são. "Em suma: as palavras têm sentido porque há objetos que elas designam: coisas singulares e essências” (DE OLIVEIRA, 2006, p. 121).

Essa função designativa é secundária, pois a linguagem, assim considerada, não participa fundamentalmente dos desenvolvimentos epistemológicos, mas tão somente os comunica. Apoiada na crítica à metafísica tradicional, a pragmática recusa que a principal função da linguagem é a designativa, uma vez que não há objetos fixos para designar cabalmente. Porém, a recusa da prioridade da função designativa está ligada a participação

\footnotetext{
${ }^{42}$ É preciso lembrar que pragmatismo e pragmática são coisas distintas: o pragmatismo é uma concepção que procura fixar um critério de validação de enunciados científicos seus resultados. Caracterizaremos o pragmatismo ao longo do texto.
} 
que a linguagem tem no desenvolvimento do nosso conhecimento do mundo, e essa relação se dá por meio do uso.

Essa espécie de pragmática linguística ${ }^{43}$ que relaciona o significado da linguagem ao uso remonta a Ludwig Wittgenstein (1889-1951). Esse filósofo possui duas principais fases: o primeiro Wittgenstein, caracterizado pela obra Tractatus Logico-Philosophicus (1922); e o segundo Wittgenstein, cujas principais teses estão presentes na obra Investigações Filosóficas (publicado postumamente no ano de $1953^{44}$ ). É nessa última obra que se fala de uma concepção pragmática em Wittgenstein e isso se deve a uma reorientação promovida a partir de alternâncias críticas de sua posição anterior ${ }^{45}$. Nessa obra, Wittgenstein apresenta a tese de que o significado de uma palavra ocorre por meio de seu uso.

Segundo ele, para se entender como uma palavra funciona "É preciso que se veja a sua aplicação e assim se aprenda" (2009, § 340). A expressividade unívoca de uma linguagem ideal é derrogada por essa nova forma de se compreender o funcionamento linguístico, na qual a linguagem é partícipe na formulação do conhecimento. Putnam está a par dessa novidade e, segundo ele próprio, é essa espécie de concepção pragmática da linguagem a que ele adere (2008b, p.67).

Em segundo lugar, estabelece-se que o tipo de objetividade para enunciados que expressam normas e os enunciados empíricos. A negação de cognitividade aos enunciados normativos (e valorativos, em geral) está fundamentada em uma hierarquização na qual os enunciados empíricos são de tal maneira superiores aos enunciados normativos, que esses não podem ser razoavelmente considerados significativos. Dito de outra forma, os critérios que legitimam a atribuição de sentido de certa classe de enunciados estão diretamente relacionados à problematização da objetividade constituída segundo critérios empíricos.

Os critérios para os quais as designações veritativas são válidas somente podem ser encontrados em enunciados empíricos, de tal sorte que frases valorativas (em amplo sentido) não são cognitivas pela evidente situação em que se encontram, qual seja, não são elas frases que estão amparadas por nosso aparato sensorial. Se não estão amparadas por nosso aparato sensorial, não são empíricas; e se não são empíricas estão fora da alçada de uma objetividade calcada em critérios empirista de validade e justificação.

\footnotetext{
${ }^{43}$ Escrevo "essa espécie de pragmática" porque há uma outra espécie de pragmática, que se entende como uma extensão da semântica. Seu arcabouço teórico está estruturado na obra de Yehoshua Bar-Hillel (1975- atual), podendo ser citado o artigo seminal de 1954, Indexical Expressions, in: Mind, Vol. 63, Pp. 359-379.

${ }^{44} \mathrm{O}$ texto publicado em 1953 com o nome de Investigações Filosóficas fora escrito em 1936-37, na Noruega.

45 Há uma tese fundamental na posição tractariana anterior, segundo a qual se "pressupõe que no mundo há entidades cuja estrutura ontológica seja claramente determinada e da qual a linguagem seria a cópia fiel" (DE OLIVEIRA, 2006, p. 131). Essa tese é flagrantemente recusada nas Investigações Filosóficas.
} 
Ora, o arco argumentativo apresentado nos dois primeiros capítulos do presente trabalho procurou mostrar as limitações dessa visada filosófica, ao refutar as assunções do positivismo lógico, registro mais recente no que se refere a um tentame sofisticado de reestabelecer e aprofundar a prevalência de enunciados empíricos e anulação sistemática do sentido de enunciados valorativos, considerados por ele pseudoproposições.

No novo cenário encetado, a objetividade é uma característica que não tem a ver exclusivamente com as questões empíricas, uma vez que ela assume acepção diversa em contextos linguísticos de uso e aplicação dos conceitos. É a aplicação dos conceitos em pano de fundo linguístico que vai garantir a objetividade. Na perspectiva putnamiana, é importante considerar a dupla dependência entre realidade e linguagem: a formação linguística dá-se por meio de um constrangimento que é promovido pela realidade, ou seja, nosso vocabulário não é independente do mundo na medida em que existe um mundo "lá fora" ao qual este vocabulário tenciona referir-se.

E, por sua vez, a realidade é expressa por formas linguísticas que apresentam limitações e que podem ser melhoradas, o que significa, em última instância, que nossa linguagem refere-se à realidade de um modo limitado, o que nos traz uma visão parcial dela. As nossas formas linguísticas objetivam capturar a realidade, mas nessa perspectiva pragmática não há uma realidade em si mesma que seja apreensível. O condicionamento da potencialidade epistemológica de nossas formas linguísticas pode nos levar a uma compreensão mais sofisticada da realidade, ou menos sofisticada. A objetividade, enfim, está referida pela capacidade que jaz na linguagem de significar o mundo pelo uso dos conceitos.

O terceiro ponto arrolado por Navia está bastante ligado ao anterior, porém com um adendo, qual seja, as razões. Ora, se um registro filosófico privilegia e enfatiza uma explicação que esteja de acordo com o mundo empírico, o registro pragmatista também o faz, embora perceba não ser possível representar o mundo tal como ele é, isto é, embora haja a impossibilidade de copiar o mundo por meio dos nossos sentidos. Na abordagem pragmatista o mote racional da justificação está articulado às potencialidades linguísticas de um esquema conceptual $^{46}$.

Está muito claro que nossos conceito são formados em ambientes culturalmente determinados, e que o instrumental fornecido por eles não são impassíveis com relação ao ambiente cultural que ensejou a elaboração de perspectivações multifárias do mundo. Pode-se

\footnotetext{
${ }^{46}$ Uso intencionalmente uma expressão putnamiana para acentuar a proposta deste texto, que é, como já fora mencionado, aproximar o leitor de perspectiva de Hilary Putnam no que toca ao assunto ora tratado.
} 
imaginar, também, que uma mesma cultura haja empreendido diversas formas de esquemas conceptuais, lavrando seus conceitos particulares, confrontando os conceitos rivais ou incompatíveis, de modo a tornar o discurso racional sobre o mundo ainda mais racional, ou seja, procurando melhorar sucessivamente as capacidades linguísticas legadas historicamente.

Nessa compreensão da linguagem e sua capacidade de conectar-se à realidade, o uso dos conceitos é determinante para estabelecer sua credibilidade e, por conseguinte, amparar sua racionalidade até seja possível desenvolver um vocabulário melhor para expressar um evento específico. As modificações as quais podem ser submetidas nossas formas de vida linguística implicam mudanças sensíveis na maneira de compreender a realidade. A realidade, compreendida de forma independente, não muda ${ }^{47}$, e isso está bem compreendido pela mensagem realista da pragmática putnamiana, segundo a qual "existe uma realidade aí fora independente de mim"; o modo de apreensão do mundo não é nunca independente de nós, (mesmo do ponto de vista epistemológico de nosso conhecimento mais basilar) o que significa que não se pode assumir uma perspectiva do "Olho de Deus".

Para uma realidade independente poder ser capturada em toda a sua independência, deveria ser ela passível de expressão linguística em toda a sua independência, mas a perspectiva em que nossa linguagem a coloca elimina, de antemão, a possibilidade de uma enunciação neutral capaz de revelar a independência requerida. Não é a negação da independência da realidade com relação a nós, mas sim a recusa de que seja exequível a tarefa de perspectivar o mundo "a partir de lugar nenhum" 48.

Destarte, se tudo isso estiver minimamente correto, a representação de uma realidade puramente independente a qual os enunciados valorativos devem estar referenciados não é factível, de modo que se procurará outro meio para legitimar esse conjunto de enunciados.

O quarto e quinto pontos listados declinam qualquer interpretação radical que se possa fazer da posição em que Putnam está. Desse modo, são rejeitadas dois tipos de ontologias, a saber, a ontologia realista e a ontologia de tipo redutivista. No primeiro caso, é postulada a existência de uma propriedade que nos forneça a capacidade especial de capturar certas entidades ou qualidades não naturais. No segundo caso, é postulada a possibilidade de reduzir o vocabulário valorativo a termos naturalistas, prescindindo, assim, de uma validade própria a enunciados de valor.

\footnotetext{
${ }^{47}$ Isto é, não muda simplesmente porque nossa linguagem muda.

${ }^{48}$ Essa é uma expressão bastante cara a Thomas Nagel, a ponto de ser o título de uma importante obra de sua autoria, The View from Nowhere (1986).
} 
A recusa a esses dois pontos demonstra uma posição equilibrada, segundo a qual os enunciados valorativos possuem status próprio, sem que, no entanto, seja necessário apelar para os antípodas acima apresentados. Segundo essa compreensão, não há um órgão de apercepção de enunciados morais, e também não há uma linguagem naturalista que possa fundamentar, em última instância, os enunciados valorativos. O primeiro caso ampara-se na dicotomia fato/valor, rechaçada por Putnam. Assim, para darmos alguma espécie de legitimidade a enunciados éticos, por exemplo, é preciso que haja um modo de "percepcionar" tais enunciados que seja análogo ao que ocorre quando percebemos os fatos por meio dos nossos sentidos. Se os enunciados que são verdadeiros ou falsos são aqueles que se referem a estados de coisas, então segue-se que se tivermos uma faculdade capaz de perceber os enunciados morais, podemos salvar sua cognitividade. A solução, portanto, é imaginar que existe um sentido interno capaz de nos conferir a faculdade de fazer essa espécie de julgamento.

No segundo caso, afasta-se peremptoriamente a moda naturalista que está cada vez mais insuflada na contemporaneidade. Se no primeiro capítulo desse trabalho apresentamos tendências fisicalistas no ambiente do positivismo lógico, agora podemos nos referir as tendências atuais de apresentar o comportamento moral numa terminologia biológica fundamentada em um arcabouço teórico evolucionista, e que se fixa em uma análise organicista neurofisiológica ${ }^{49}$.

Destarte, a objetividade moral não está fundamentada nem em um realismo do "senso moral" (em que pese uma consciência moral capaz de indicar imediatamente a correção e a incorreção de atos morais), nem em um realismo de tendências naturalistas que esvazie os enunciados valorativos de uma validade própria.

Dito isso, iremos apresentar o debate enfatizando a posição putnamiana, tal como ocorreu nessa rodada de palestras. Procuramos antes fixar pontos comuns por que o debate enfoca as distinções entre ambos os filósofos. É muito comum que um compreenda de modo equivocado a posição do outro, principalmente quando discordam. Apesar disso, estamos convencidos de que há um aclaramento das questões por meio do debate, e um uso de certos conceitos que foram elaborados no capítulo anterior. Dito isso, comecemos a exposição.

\footnotetext{
${ }^{49}$ Uma obra de relativa repercussão que pode ser emblemática nesse tocante é o livro de Sam Harris, filósofo e neurocientista estadunidense, intitulado A paisagem Moral: como a ciência pode determinar valores humanos, publicado originalmente em 2010, e publicado em língua portuguesa em 2013.
} 


\subsection{A Dicotomia "Normas/Valores" e as Palavras Eticamente Espessas}

Putnam passa à análise do binômio conceptual que é o cerne de seu debate com Habermas, qual seja, a dicotomia normas e valores. Para alargar o tema, a interpretação da posição de Habermas é temporariamente posta de lado. Dessa forma, Putnam pretende gerar mais elementos para que o debate com Habermas torne-se mais profícuo e rico.

Para Putnam, os termos que seriam utilizados em nossa 'máximas' e 'leis' não são neutros do seu ponto de vista valorativo, pois eles mesmos contêm termos valorativos " ${ }^{50}$, mais apropriadamente "palavras éticas espessas", como por exemplo, "gentil”, “cruel", "impertinente", etc. Palavras eticamente espessas, consoante tratado no segundo capítulo, são aquelas cujo uso pode implicar propósitos normativos e/ou descritivos. Assim, "gentil” referese a um comportamento factual que não pode ser desvencilhado de posições valorativas atinentes ao próprio significado da ação intrínseca à palavra em questão.

Não há, destarte, uma estanque distinção entre fato e valor quando tratamos de palavras éticas espessas. Putnam diz-nos, como exemplo, que temos como uma regra de conduta o dever de tratar com "bondade" (palavra eticamente espessa) os indivíduos com os quais nos relacionamos, e que este tratamento deve ser especialmente dirigido àqueles que se encontram em situação difícil.

Ora, se nos coadunarmos à ideia de que fato e valor estão separados de modo estanque $^{51}$, termos considerados eticamente espessos, como "bondoso", "sensível”, "cruel”, não representariam conteúdo valorativo, ou seja, poderiam ser, na linguagem adotada por Putnam, "fatorados" em um "componente descritivo" e em um distinto "componente valorativo", ambos independentes entre si. Todavia, estes termos supracitados não representam propriedades descritivas neutras. Isto pode ser visualizado pelo fato de que não podemos considerá-los unicamente por meio do seu conteúdo descritivo, ou, como expressa melhor Putnam, seu conteúdo "somente está disponível através das lentes dos conceitos de valor" (2008a, p. 158) $)^{52}$.

\footnotetext{
${ }^{50}$ No texto de Putnam a expressão também aparece em itálico.

${ }^{51}$ A questão sugerida a Putnam, que está desde sempre insinuada e que assume agora centralidade, é posta por Iris Murdoch ao criticar, a uma só vez, o existencialismo e o positivismo lógico por compartilharem "uma imagem da mente como se ela fosse dividida em 'faculdades' discretas, uma imagem na qual a percepção fornece fatos 'neutros' e os valores vêm da vontade". A questão é tratada por Murdoch em sua obra The sovereignty of good. (1971).

${ }^{52}$ Revelando o fio condutor de sua argumentação em outra direção, Putnam expõe que, desde Razão, Verdade e História, tem considerado que "os termos de valor são, ao mesmo tempo, conceitualmente indispensáveis e irredutíveis a termos meramente descritivos" (2008a, p.159). Essa consideração expõe, novamente, a posição de Putnam de que objetividade não é somente descrição, o que se contrapõe às noções naturalistas. Ele concluiu, em Razão, Verdade e História, que “... a ética não entra em conflito com a física, como o termo 'acientífico' sugere; simplesmente, 'justo', bom e 'senso de justiça' são conceitos em um discurso que não é redutível ao discurso da física [...] Outros tipos de discursos essenciais não são redutíveis ao discurso da física e eles não são ilegítimos por essa razão. Falar de 'justiça' como se fala de 'referência' pode ser não-científico sem ser acientífico" (PUTNAM, 2008a, p. 159). Putnam entabula, assim, uma discussão
} 
Putnam parte de um caso hipotético em que há um conceito ético espesso utilizado em um mundo social específico e que, de outra forma, não é utilizado em um mundo social distinto daquele. Ele supõe também que este conceito é a "castidade", por tê-lo como um conceito que não está em uso em todos os possíveis mundos sociais, mas, antes, está circunscrito a apenas alguns, mantendo, não obstante, significado e forma que o possibilita ser universalizado. Se tentarmos aplicar o sentido de um conceito eticamente espesso a um mundo social que não the corresponda, enunciando, por exemplo, "seja casto", este sentido estará esvaziado, embora o interlocutor consiga entender o significado do proferimento ${ }^{53}$.

A primeira resposta que Putnam oferece apresenta-se a partir da seguinte questão: "Você deve adotar este conceito?". Caso respondamos à interrogação com um "sim", será oportuno responder a outra questão adicional: "Você deve aceitar a norma que eu supus forjada no uso do conceito?” (2008a, pp. 161-162).

Putnam vê isto como problemático para a ética discursiva, pois a discussão pressuporia que a questão tivesse um conteúdo cognitivamente relevante. Se a questão trazida à baila não for cognitivamente relevante, diz-nos Putnam, poderemos dizer que a discussão será unicamente uma série de afirmações acerca de valores e, neste caso específico, de valores comutados em normas, cujo sentido não é apreendido pelo interlocutor participante do discurso.

com Bernard Williams. Esse filósofo proclama e defende duas teses naturalistas fortes: 1) Os únicos conceitos capazes de descrever os objetos do mundo são os conceitos científicos. 2) Os únicos conceitos verdadeiramente científicos são os conceitos da física. Se Bernard Williams acredita, assim como Putnam, que os termos eticamente espessos não podem ser considerados de modo estanque em seus componentes descritivos e avaliativos, ele considera que nossas afirmações que se utilizam deles não podem ser tidas como asseverações com validade absoluta. Não obstante, estamos habilitados a dizer de uma frase ética que ela é verdadeira, por que 'verdadeiro', para Bernard Williams, é um adjetivo, e pode ser utilizado com propriedade quando se fala no "interior de um mundo social ou outro", bem como quando se fala "absolutamente" (WILLIAMS, 1985, apud PUTNAM, 2008a, p.160). Para maiores detalhes com relação às interessantes considerações que Putnam faz acerca de Bernard Williams, ver a obra de Putnam Renovar a Filosofia (1999b), capitulo 5. Putnam explica que "absoluto" é uma noção fundamental no sistema de Bernard Williams. Falar "absolutamente" significa expressar uma "concepção absoluta de mundo". Segundo B. Williams, "We can select among our beliefs and features of our world picture some that we can reasonably claim to represent the world in a way to the maximum degree independent of our perspective and its peculiarities. The resultant picture of things, if we can carry through this task, can be called the 'absolute conception' of the world" (WILLIAMS, 2006, 138-139). Desse modo, fica claro o que uma concepção absoluta quer dizer. Ela é uma concepção segundo a qual estaremos mais próximos da realidade conforme nossas formas de expressarmos essa realidade intervirem cada vez menos no modo como a realidade é, independentemente de nossas considerações. Isso significa que devemos eliminar qualquer componente de subjetividade, caso queiramos um quadro objetivo do mundo.Com isso não se está a afirmar que certo enunciado ético pode ser verdadeiro em uma cultura e, ao mesmo tempo, falso em outra, mas tão somente que só é possível falar que um determinado enunciado ético é verdadeiro no interior do 'mundo social' no qual o houve o proferimento (PUTNAM, 1999b, p. 129). O conjunto formado pelas outras culturas restantes é desconsiderado. Para Putnam, a importância dessas considerações está no fato de que, para uma ética que se pretenda universal, coerência interna não é suficiente. Isso porque a implicação de assumir uma ética de cunho kantiana é a universalização dos conceitos éticos espessos. E nesse caso não haveria uma significação universal para tais conceitos, uma vez que sua validade estará antecipadamente restrita ao contexto originário, ou segundo Putnam "no interior do mundo social" nos quais eles foram concebidos. Há, assim, uma problematização sobre as "extensões desses conceitos éticos" (2008a, p. 161), pois eles não possuiriam, no sistema ora considerado, inteligibilidade universal. Não poderemos atravessar barreiras de mundos sociais, o que significa dizer que a validade e a referência destes conceitos dirão respeito a indivíduos específicos. Mesmo que as normatizações aplicadas a mundos sociais particulares tenham uma universalidade formal, ainda assim o conteúdo plasmado à forma não terá esta característica requerida por um sistema ético que se pretenda kantiano. Putnam arremata que o "relativismo de qualquer tipo com relação aos valores não pode deixar intactas as "normas"” (2008a, p. 162). Por causa da especificidade deste trabalho, não poderemos nos delongar nas considerações que Putnam faz com relação às asserções de B. Williams.

${ }^{53}$ Porém, ele há de considerar que o conceito em questão é extemporâneo. Este é um delineamento da questão com feições que Putnam atribui a Bernard Williams, pois se a teoria desse estiver correta é desta maneira que deveremos visualizar a dinâmica ética imposta pelos vários mundos sociais, o que significaria, nessa esfera "supor que não existe uma extensão do conceito independente-do-todo-social" (2008a, p.161). 
Isso, na prática, resultaria na ausência de objetividade mínima dos valores e, por consequência, das normas, e estaríamos em todas as discussões somente a dizer, em última análise, que uma norma (calcada em um valor) é plena de sentido para nós, enquanto que nosso interlocutor afirmaria que esta norma lhe é destituída de sentido, retorquindo com uma norma que para ele é usual.

Com isso, seria fatal para a ética discursiva ter os valores em conta de meros objetos de disputa, o que resultaria, segundo Putnam, em uma espécie de "sociologismo com relação aos valores". Assim, trataríamos os conflitos sociais como um simples conflito social ocasionado por valores postos e, tão somente do ponto de vista do conflito resolver-se-ia a questão, abandonando-se, assim, o instituto de que o mais apropriado a se fazer é dirimir os "desacordos racionais exigindo uma decisão sobre onde se encontram as melhores razões" (2008a, p. 162).

Para Putnam, apesar de nossos vocabulários serem diferentemente complexos, sempre é possível engajar-nos na discussão, na perspectiva preconizada pelo agir comunicativo no tocante às normas. Este engajamento almeja o entendimento comum, feito por meio da racionalidade, com vistas a formar um vocabulário no qual os concernidos possam, quando da sua aplicação, compreenderem-se mutuamente.

Segundo Putnam, para que as respostas às duas questões feitas ("Você deve adotar este conceito?" e "Você deve aceitar a norma que eu supus forjada no uso do conceito?") sejam consideradas como aquelas que procuram dar as melhores razões, teríamos que estar seguros, de antemão, que há uma resposta correta que possamos dar. A menos que isso seja feito, não teremos condições de elevar a discussão para além de um simples palavrório ${ }^{54}$.

A segunda resposta que Putnam nos dá circunscreve uma posição de Habermas com relação à ética discursiva, anterior ao livro Teoria da ação comunicativa, em que o suporte que lhe é dado remete à "pragmática transcendental" de Karl Otto Apel ${ }^{55}$. Ainda segundo Putnam, o cerne do que propõe Apel neste tocante é a identificação da verdade "com aquilo com o que podemos concordar nos limites da discussão indefinidamente continuada." (2008a,

\footnotetext{
${ }^{54}$ De acordo com Richard Rorty, recuperado por Putnam, não haveria outra função no debate que não a de "continuar a conversação" (2008a, p.163).

${ }_{55}$ Putnam nos revela, neste ponto, prestar uma resposta que não leva em conta a Teoria do agir comunicativo, publicado em 1984, mas prefere se valer da pragmática transcendental característica da época em que Habermas trabalhava próximo a Apel .Com isto, mais uma vez podemos entender melhor que o objetivo de Putnam não é tão somente fazer uma análise erudita das teorias de Habermas (pois como poderia fazê-lo sem levar em consideração os mais recente desenvolvimentos proporcionados por Habermas?), mas, sim, utilizar este filósofo para melhor expor suas convicções, conquanto evite alinhavar uma análise apartada daquilo que o próprio Habermas tencionou em seu filosofar. Aqui temos uma característica deste debate: Putnam "serve-se" da ocasião para demonstrar o pensamento que está explícito em suas outras obras (exatamente as tratadas no segundo capítulo desta dissertação) e sua posição é marcadamente contrária a que os valores não sejam, $a$ priori, objetivos.
} 
p. 163); e esta afirmação é também aplicada à classe de afirmações éticas, bem como a todo o universo discursivo.

A afirmação de uma discussão indefinidamente continuada como identificação da verdade pode nos levar a concluir, na opinião de Putnam, que se não há plausibilidade em esperar que o desacordo seja resolvido, então o conceito (de castidade, por exemplo) deve ser alijado.

Putnam continua com a afirmação de que no caso específico:

"não há nenhuma verdade em qualquer um dos lados, por que se houvesse verdades (ou enunciados válidos) sobre (a) quais ações são castas e quais não o são ou (b) se a máxima 'evita o comportamento que não é casto' deve ser universalizada, então essas verdades seriam eventualmente acordadas por todos os participantes da discussão (ideal) que vislumbramos porque esse é o próprio sentido de 'verdade'. Se, por outro lado, existem verdades sobre (a) e (b), então novamente, pela própria definição de "verdade", a discussão suficientemente continuada deve (em condições ideais) convergir para elas. (PUTNAM, 2008a, p. 164)

$\mathrm{Na}$ visão de Apel, afirmações do mesmo tipo (conceitos éticos espessos) podem ter validade universal, e é a dinâmica ensejada na ética discursiva que poderá demonstrar-nos qual afirmação logrará êxito.

Putnam analisará, a seguir, se esta visão apeliana é adequada a partir da consideração de duas questões: (1) Se está ele, Apel, "certo em endossar a definição de verdade de Peirce" (2) E, no caso de uma resposta negativa, se a definição "poderia ela ainda assim ser correta para enunciados éticos?”.

\subsubsection{Sobre a Teoria da Verdade Adotada por Apel}

Como foi dito na seção anterior, a teoria apeliana da verdade é tomada de Charles Sanders Peirce ${ }^{56}$, pragmatista norte americano, razão pela qual Putnam a chama de posição Peirce-Apel. Acerca disto, comenta que se nos propuséssemos a tornar tal posição aceitável para os critérios contemporâneos de clareza, teríamos que preservar a característica de que "é metafisicamente impossível que existam quaisquer verdades que não sejam verificáveis pelos seres humanos" (2008a, p. 165). Isso ocorreria porque a discussão ideal, como veremos,

\footnotetext{
${ }^{56}$ Charles Sanders Peirce, pensador norte-americado, (1838-1914), foi o iniciador do tradição filosófica que até hoje é conhecida como "pragmastismo", posteriormente desenvolvida por William James (1842-1910), John Dewey (1859-1952) e Georg Hebert Mead (18631931). Como figura fundadora do pragmatismo, podemos encontrar uma exposição de suas ideias no ensaio Como tornar nossas ideias claras (How to Make our Ideas Clear, 1878), no qual ele diz que "a opinião que está destinada a encontrar o consenso último de todos os que investigam é o que 'verdade' quer dizer, e o objeto representado nessa opinião é o 'real'”.
} 
precisa convergir para um discurso correto. Se houver alguma verdade metafisicamente impossível, então a via da discussão ideal se fecha para a possibilidade de conduzir-nos à verdade.

Essa posição é resultado do que hodiernamente é classificado de antirrealismo, "porque torna os limites do que pode ser verdadeiro no mundo dependente das capacidades humanas de verificação" (2008a, p. 165), ou seja, tudo o que estiver fora da possibilidade de submeter-se aos nossos critérios de verificação não poderá ser asseverado como verdadeiro ou falso. Esta é uma forma de enunciar o princípio de verificabilidade como critério de verdade. Para Putnam, o argumento do filósofo antirrealista sempre está, de algum modo, a assumir um tom recriminatório para com a ideia de que "as verdades podem algumas vezes não ser verificáveis, mesmo que idealmente", tom este assumido para designar o componente inextirpável, qualificado, depreciativamente, de 'metafísica' (2008a, p.165).

Putnam obtempera que dificilmente alguém estaria disposto a sustentar que a frase “deve ser impossível para qualquer um conhecer fatos da vida de Moisés" possa ser tomada metafisicamente, no mesmo sentido que a palavra tem para o antirrealista. Putnam afirma que alegar não existirem verdades acerca da vida de Moisés, simplesmente porque atualmente não dispomos de meios para verifica-las, é o que parece "metafísico", no sentido depreciativo utilizado pelo antirrealista, qual seja, o sentido em que metafísica e senso comum se opõem totalmente. Mas ele observa que estas dificuldades de cunho verificacional são partilhadas em âmbitos tidos como tradicionalmente separados, resultando na convicção da contingencialidade acerca da verdade que podemos apreender no mundo, compreendida como a impossibilidade do critério de verificabilidade para fundamentar todos os casos com os quais nos defrontamos:

\footnotetext{
Trata-se, ao contrário, de algo que faz parte tanto da ciência como do senso comum, algo que está profundamente impregnado nas visões de mundo da ciência e do senso comum, que é uma questão totalmente contingente se toda verdade poderia, ainda que 'em princípio', ser aprendida por seres como nós mesmos (2008a, p. 166)
}

A postura de Putnam com relação à teoria da verdade de Peirce e Apel, fundamental à pragmática transcendental, é considerá-la um engano que precisa ser alijado, caso ela seja resultado de uma teoria antirrealista. 
Putnam lança a questão: "Se a definição de verdade de Peirce não é correta para os enunciados descritivos, incluindo os enunciados da ciência física, poderia ela ainda assim ser correta para os enunciados éticos?" (PUTNAM, 2008a, pp.166-167). A importância da questão reside no fato de as perspectivas diferenciadas do mundo, configuradas tanto pelo realismo científico quanto pelo realismo do senso comum, serem carentes de instrumentos para dissolver o problema que surge da impossibilidade de verificação de determinadas afirmações.

Apesar disso, Putnam não considera que a ausência de possibilidade de verificação de certos tipos de enunciados os relega a uma esfera na qual não poderão ser tomados como verdadeiros ou falsos. Continua sua reflexão ao afirmar que os eticistas mantêm uma opinião já tradicional, na qual os deveres podem ser conhecidos por nós, porquanto, se não fosse assim, não poderiam sequer ser deveres levados por nós a um estado procedural. Isto, contudo, não dissuade Putnam de pensar que a teoria da verdade apeliana possa ser salva ao considerá-la unicamente do seu ponto de vista ético.

Putnam afirma que "o ponto crítico é a justificação da passagem de dizer que qualquer alegação verdadeira sobre os nossos deveres" tenha que ser considerada "cognoscível por nós" para a afirmação de que estas alegações seriam "o resultado de uma discussão ideal, se essa discussão fosse suficientemente prolongada" (2008a, p.167). Para explicar o quão problemática é esta passagem, Putnam recorre à interseção entre valor e norma, e divide esta análise da justificação da passagem em três problematizações.

Na primeira parte da problematização, Putnam obtempera que todos os partícipes da discussão ideal deverão estar concordes no que diz respeito às normas que viabilizam a dinâmica da ação comunicativa. Isto quer dizer que os membros engajados devem "falar honestamente"; 'justificar o que é dito'; 'argumentar racionalmente e com isto procurar vencer debates, ao invés de valer-se de métodos escusos', etc. A "situação de discussão ideal" requer que haja uma admissão de todas as normatizações e máximas que irão ter como consequência a operacionalização dos procedimentos com vistas a gerar o contexto ideal de fala.

Para Putnam, se esta é a exigência intrínseca da qual os participantes engajados na discussão ideal não poderão se esquivar, então a justificação (que é o cerne da ética de Habermas) destas normas e máximas, cujo objetivo é proporcionar a situação de fala ideal, não significará que ela seja resultado "de uma enquete peirceana indefinidamente prolongada" (2008a, p. 167). Em outras palavras, os resultados considerados promissores que estão 
constantes na situação de discussão ideal não são proporcionados pela sua fundamentação em uma teoria da verdade tal como a concebem Apel-Peirce.

Pondera Putnam que a resposta de Apel contra estas afirmações baseia-se na alegação de que as máximas e normas viabilizadoras da discussão ideal estão "justificadas por uma 'justificação transcendental', ou seja, que são pressupostas pela racionalidade, pressupostas pelos procedimentos que definem o que é procurar a verdade." (2008a, p. 168).

Caso a definição de verdade estiver condicionada "ao produto do consenso ideal" acerca de assertivas éticas, seguirá que o próprio argumento transcendental também estará restringido às mesmas condições. A decorrência disto é que as normas e máximas, nas quais está baseada a ética discursiva, estão pressupostas neste mesmo esquema da racionalidade ética.

Ainda que concedamos que seguir as normas e máximas da ética discursiva seja uma “condição necessária” para justificar asseverações éticas, faltar-nos-ia avaliar se isto serve para uma afirmação mais forte, qual seja, que estas mesmas normas e máximas estabelecem uma "condição suficiente" para amparar nossas crenças éticas. É esta preocupação que forma a segunda parte da problematização que Putnam propõe.

Neste ponto, Putnam questiona se, ainda que nós não levemos em consideração as questões trazidas pela forma contrafactual posta na frase 'se a discussão efetivamente estendida de modo ilimitado', haveria um modo razoável de imaginar uma concepção de mundo que fosse clara o suficiente para que fundamentássemos a noção de pessoas "capazes de discutir um assunto para sempre?" Embalado por esta questão, Putnam adianta sua resposta: "argumentarei que não há razão para acreditar que o resultado de uma discussão ideal e suficientemente prolongada sobre uma questão ética seria inevitavelmente correto" (2008a, p.168).

Não estamos municiados, obtempera Putnam, de uma ciência que seja capaz de nos fornecer um aparato para que tenhamos a competência de fazer estas distinções ${ }^{57}$.

Putnam julga ter chegado à constatação de uma ambiguidade fundamental da posição de Habermas. Para evitar a ambiguidade, ele propõe que Habermas restrinja as alegações da ética discursiva. Isto significa, na prática, assentir que a ética discursiva é somente uma "parte" da ética, evidentemente uma parte importante, todavia, uma parte que não pode ser

\footnotetext{
${ }^{57}$ Putnam, neste ponto, cita Iris Murdoch, que alega que esta habilidade é "infinitamente aperfeiçoável” e "está ligada com nossa maestria (também infinitamente aperfeiçoável) no próprio vocabulário moral” (PUTNAM, 2008a, p. 172 citando MURDOCH, 1971, p.28-37). Para maiores informações, $O p$. cit 39.
} 
tida como independente, ou seja, a ética discursiva não poderia ser automantida, muito menos poderia ser a fundamentação de toda a validade do universo de enunciados éticos. Afora isto, Putnam avalia que Habermas está no caminho correto.

Por outro lado, se a situação de fala ideal é o que vai garantir um veredito correto em ocasiões éticas, significando com isso que este veredito "surgirá se os competidores forem idealmente sensíveis moralmente, imaginativos, imparciais etc.", segue-se que "a alegação é puramente 'gramatical'". Nela não há conteúdo que possa ser acoplado à "noção de "veredito correto em uma disputa ética"”. Os conceitos que poderiam fornecer conteúdos são aqueles que seriam eticamente espessos (PUTNAM, 2008a, p. 172).

A configuração da problematização se dá, segundo Putnam, "no interior do enfoque kantiano”. Para ele, “o kantismo procura princípios característicos da própria razão prática, enquanto trata valores como meros fatos psicológicos ('impulsos psicológicos naturais')" (2008a, p.173). Muitas dificuldades são supervenientes à distinção kantiana com relação à inclinação e razão, que assume a forma de uma dicotomia, e que forçosamente nos conduz à dicotomia fato/valor. Esta configuração atual do problema nos impede de visualizar que os conceitos éticos espessos desafiam a oposição tradicional entre fato/valor.

\subsubsection{Naturalização e Relativização de Valores}

Putnam avalia que há uma forte vontade geral de naturalizar-se a ética. O naturalismo, entendido como materialismo, apresenta uma descrição em que é negada a enunciados éticos a qualidade de serem proposições, ou seja, sentenças éticas não são juízos que podem receber um valor designado, segundo o qual poderíamos dizer que se trata de afirmações verdadeiras ou falsas. Os enunciados éticos, a partir das múltiplas descrições naturalistas, não podem ser proposições sem que haja uma suplementação da informação do contexto ao qual se referem.

Portanto, a declaração de que uma atitude ética $x$ é verdadeira, somente pode ser validada se estiver referida a um contexto anteriormente acordado $y$. Assim, $x$ é verdadeiro em $y$. Isto não quer dizer que $x$ é verdadeiro. Tal afirmação seria incorreta. Para darmos garantias de que $x$ é verdadeiro, a complementação necessária para legitimar os enunciados deve estar baseada em frases como "no mundo social relevante" ou $x$ é "relativo a desejos e atitudes individuais" (PUTNAM, 2008a, p. 174). A proposta naturalista impossibilita, por causa de suas assunções iniciais, que as declarações éticas não sejam relativas a contextos 
determinados, o que nos leva à confirmação, em suas descrições típicas, de que a ética é peremptoriamente relativa.

No caso de concordarem que possa existir algo como enunciados éticos objetivos e “completamente racionais", há uma necessidade das descrições naturalistas de "dar um tratamento ao propósito (e algumas vezes ao conteúdo) desses juízos em termos não-éticos" (PUTNAM, 2008a, p. 174). O que significa dizer que as descrições naturalistas poderiam supor que os enunciados éticos são objetivos por se situarem em um contexto capaz de gerar certa decidibilidade em casos específicos, nos quais procedimentos podem ser acionados a partir da argumentação racional inferida por um esquema que não é puramente (ou nada) ético. ${ }^{58}$.

Putnam está convencido de que o projeto de naturalizar os enunciados éticos pode nos conduzir à estratégia calamitosa, levada a cabo pelo positivismo lógico, em que admitiremos a um cético hipotético que não temos o conhecimento necessário para, no caso da ciência, asseverarmos qualquer coisa sobre inobserváveis. O que tem como consequência que não teremos qualquer tipo de certeza com relação a objetos, sejam quais forem, quando esses não estiverem no âmbito da possibilidade de nossa constatação sensorial.

Em suma, não poderemos afirmar que objetos não verificados pelo nosso sistema sensório existem de modo independente de nossa mente. Entretanto, não poderíamos abrir mão de alegar um mínimo capaz de nos habilitar a fazer predições seguras. Para Putnam, esta imagem científica positivista de mundo não está mais em voga, mas serve-nos para analisar o caso particular da ética.

A partir da reflexão feita por Putnam sobre as posições do positivismo lógico, ele declara que "o pensamento correspondente é de que podemos conceder ao cético que não temos conhecimento ético irredutível" (PUTNAM, 2008a, p. 175). Não haveria por que afirmar, desta forma, que a comiseração que um indivíduo sente frente a um necessitado, e a obrigação moral de auxílio ensejada, por exemplo, seja uma espécie de conhecimento moral. Para Putnam, não deveríamos tomar este sentimento como simples sentimento desvinculado de obrigações morais. Isso Putnam explica a seguir com uma relação entre a ética e o positivismo lógico.

\footnotetext{
${ }^{58}$ Destarte, os múltiplos modos de abordarmos os juízos éticos, por exemplo, a tomada evolucionista, utilitarista e contratualista, têm, em última instância, uma origem externa em sua justificação, por não se tratar de uma justificação feita a partir de um sistema ético considerado enquanto tal. Para Putnam, os três exemplos encontram sua justificação externamente. A abordagem evolucionista, por pressupor mecanismos naturais reguladores da ação com repercussão nos enunciados éticos, como a impulso natural à "sobrevivência". O utilitarismo, por impor uma norma segundo a qual os enunciados éticos são considerações resultadas de cálculos feitos a partir da perspectiva de utilidade de um grupo. O contratualismo, por procurar "dar razões apreciáveis por si mesmas", sem que isto esteja em conexão direta com uma perspectiva ética, mantendo como valor do seu procedimento racional a "imparcialidade (PUTNAM,2008a, pp. 174-175).
} 
O positivismo lógico procurou mostrar, em grande parte, que a ciência pode ser operacionalizada sem que haja necessidade de admitir a existência de valores epistêmicos em seu interior, e sem conceder que ela seja irredutível a estes valores. O projeto do positivismo não era apontar impropriedades à ética e negar a existência de valores éticos ${ }^{59}$. No entanto, as ciências têm juízos que lhe estão pressupostos, e que são fundamentais para que resultados a ela requeridos, como por exemplo, a capacidade preditiva, sejam levados a cabo.

A coerência, a simplicidade, a plausibilidade são exemplos bastante evidentes de como a ciência norteia-se por valores. Para Putnam, tudo o que tem sido dito baseado em argumentos a favor do contextualismo e relativismo ético poderia ser dito de modo análogo com relação aos valores epistêmicos:

O argumento de que os valores éticos são metafisicamente anômalos (porque, entre outras coisas, não temos um órgão sensorial para perceber 'o bom') poderia transformar-se no enunciado 'os valores epistêmicos são ontologicamente anômalos' (porque não temos um órgão sensorial para perceber simplicidade e coerência). (2008b, p. 76).

Destarte, os argumentos relativistas e não-cognitivistas com relação à ética estão fundamentados na variedade perceptível no tocante aos valores éticos nas diversas culturas humanas e a incompatibilidade de suas noções valorativas, que implicam, muitas vezes, visões de mundo sustentadas a partir destes valores. Esta é uma faceta do relativismo ${ }^{60}$.

Contudo, poder-se-ia iniciar, partindo-se da desarmonia subjacente aos mundos éticos distintos, a avaliação de qual conjunto de crenças éticas apresenta maior 'coerência', 'plausibilidade', 'capacidade de explicar com simplicidade os fatos e ocorrências no mundo'. Com relação à desarmonia, e consequente falta de acordo entre as culturas distintas, Putnam afirma que tanto eticistas quanto cientistas naturais estariam dispostos a dizer que não há objetividade em seus enunciados culturais que possam ser universalmente válidos.

Assim, no caso de o argumento relativista realmente provar que os valores éticos são relativos e contextuais, ele também provará, por analogia, que os valores epistêmicos padecem da mesma fragilidade. Para Putnam, no lugar de nos contentarmos com o argumento relativista em ambos os casos, deveríamos compreender melhor a indispensabilidade de tais valores, sejam eles éticos ou epistêmicos, para nossa vida.

\footnotetext{
${ }^{59}$ Carnap dedicou-se ao projeto de demonstrar que a ciência utiliza um sistema sintático formal. E Popper tenta contradizer a lógica indutiva de Carnap ao enunciar sua famosa regra de falseabilidade, segundo a qual quando houver disputas em torno de qual teoria adotar, devemos falseá-las e escolher aquelas que resistam (melhor) ao teste. Putnam lembra-nos de uma afirmação de Quine, em que este nos ensina que a decisão entre teorias é um "assunto de equilíbrios que são "pragmáticos, onde são racionais", o que significa que nestes casos, avaliamos a "plausibilidade", "simplicidade" e critérios desse jaez. Não acontece, quando de um conflito entre teorias, que essas sejam dirimidas por si somente, coisa que os cientistas não esperam que aconteça. (PUTNAM, 2008b, pp. 74-75).

${ }^{60}$ Putnam nos diz que o não-cognitivismo foi rebatizado com o nome de relativismo (1999, p. 240). Desse modo, a noção de nãocognitivismo pode ser considerada uma definição de relativismo, na perspectiva de Putnam.
} 
Se nossos critérios de aceitabilidade fizerem-nos exigir explicações redutivas, ou, de outro modo, se requerermos fundamentações naturalistas, estariam excluídos, de uma vez por todas, além dos pronunciamentos éticos, os discursos de referência, a causalidade, os enunciados contrafactuais, etc. Putnam declara que, por tudo isto, o erro está nas pressuposições do naturalismo, e não na discursividade ética.

Putnam, enfim, conclui suas considerações acerca da ética discursiva de Habermas citando um chiste desse filósofo, segundo o qual "nós precisamos de alguns imperativos categóricos, mas não de muitos", e segue a dizer que admitir que os valores devam ser discutidos racionalmente, mesmo que não devam ser naturalizados, não significa o mesmo que aceitar um provável caráter apriorístico e autoritário destes valores (PUTNAM, 2008a, p. 177). Declara Putnam que, posteriormente ao abandono das convicções éticas fundadas em noções divinas, temos sido falibilistas, o que nos impede de sermos arrojados no momento precípuo de asseverar a possibilidade de que valores éticos possam ser tomados como objetivos.

Contudo, segundo Putnam, o falibilismo não é uma condição suficiente para a totalidade da investigação ética. Desse modo, a ética do discurso poderia ser compreendida como uma via pela qual uma investigação ética racional pode nos dar maiores pormenores a respeito do que seria uma racionalidade aplicada ao caso específico da ética, embora a ética discursiva não deva ser considerada tudo o que pode ser dito acerca da ética em geral. As exigências que os valores proporcionam são, quando percebidas por nós, exatamente o conteúdo da ética discursiva (2008a, p. 178).

\subsection{A Resposta de Jürgen Habermas a Putnam}

A resposta que Habermas nos dá sobre as considerações que Putnam faz à sua ética está muito além de um comentário direto, ou melhor, restrito, às interpretações que este faz de sua obra. Habermas procura nos fornecer um fio condutor a partir do qual poderemos seguir a argumentação putnamiana, baseados em uma história de seu desenvolvimento filosófico, porém uma história conceitual, posicionando uma interpretação particular do enquadramento dos conceitos na obra de Putnam.

As elucidações habermasianas são singulares, e às vezes são proponentes de certas assunções que o próprio Putnam irá contestar. Todavia, a discussão em torno das questões ora aqui tratadas trazem à baila problemas que o próprio autor da posição inicial, no caso Putnam, 
poderia ter não se dado conta. Por isso, este autor pensa que é muito a propósito que tenhamos em mente as críticas e intepretações de Habermas, a fim de que possamos situarmo-nos melhor no tema concernente à objetividade dos valores do ponto de vista de sua fundamentação epistemológica.

Habermas afirma que Putnam tem iniciado, há algum tempo uma dura crítica ao empirismo lógico, compreendida como uma reconsideração das bases nas quais esse se sustenta, expondo, assim, seus antigos mentores Carnap e Reinchenbach. Apesar disto, teria mantido um "ethos científico e a sua mentalidade kantiana". A formulação da crítica putnamiana aos seus antigos companheiros e a adoção do ethos científico cum kantismo produziu uma posição singular, o pragmatismo kantiano. Segundo Habermas, "Putnam assimila a aproximação transcendental dentro de uma concepção linguística e lhe imprime um giro realista" (2008b, p. 79).

Há, na interpretação de Habermas, a convicção de que Putnam submete o sujeito cognoscente e atuante a uma destranscendentalização de certas bases metafísicas no tocante à clássica distinção entre os mundos inteligível e das aparências: este é um dos resultados da crítica de Putnam à metafísica clássica (e também ao realismo tradicional). Todavia, Habermas nos assegura que a parte central da filosofia de Kant permanece inalterada, tomando por 'parte central', o autoentendimento racional de indivíduos que são racionais, ou seja, indivíduos que baseiam o entendimento de si mesmos na racionalidade; e indivíduos para os quais tal entendimento racional está caracterizado pelas noções de finitude e de autonomia. (2008b, p.79)

Putnam está, de acordo com Habermas, próximo a Kant no que diz respeito à autoridade da ciência, ou seja, reconhece-a, não obstante pense, juntamente com esse filósofo, que devamos nos opor à afirmação autoproclamada de autoridade da ciência, uma recusa que deixa caminho aberto para o desenvolvimento de uma razão prática. Assim, temos que, para Habermas, Putnam julga que o mundo da vida é também racional, precisamente no que respeita ao senso comum e à moralidade, não procurando, todavia, alcançar a sistematização deste estatuto por meio de uma distinção estanque entre as razões prática e teórica.

Putnam não nos fornece uma separação clássica entre os juízos éticos e os juízos de valor, muito pelo contrário. Há, no entender de Habermas, uma equivalência entre a objetividade dos valores e a verdade de enunciados éticos. E, diferentemente de Kant, não pensa que a validade de juízos éticos está em situação distinta dos enunciados empíricos 
tradicionais. Os juízos de valor e os juízos éticos estão em franca continuidade no que é pertinente à validade.

De fato, a tessitura da nossa realidade está tão definida pelo uso dos valores que nos servem de instrumentos para darmos a ela uma configuração racionalmente compreensível, que seria sem sentido anelar a eliminação dos valores na formação da nossa configuração do mundo (caso a hipótese de eliminação fosse possível, coisa com a qual Putnam não concordaria).

Aos enunciados empíricos está subjacentes toda uma gama de valores (epistêmicos, por exemplo) e, entretanto , não são levantadas dúvidas sérias com respeito ao status de 'verdadeiros' desses enunciados, ainda que eles estejam comprometidos com valores. Qualquer pesquisador 'sério' julgaria absurdo pensar que nossos enunciados empíricos não podem ser verdadeiros ou falsos. De igual modo, Putnam nos lembra, segundo Habermas, que os enunciados valorativos que tenham como componente a mesma gama de valores devem receber o mesmo status epistêmico.

O itinerário que Habermas seguirá é dividido em duas partes e definido da seguinte maneira. Na parte inicial, em primeiro lugar, procurará demonstrar que, no tocante à epistemologia, Putnam é um herdeiro kantiano. Em segundo lugar, tentará provar que a epistemologia de base kantiana tem como consequência gerar um realismo pós-metafísico. $\mathrm{O}$ terceiro e o quarto passos nos mostrarão que um realismo assim caracterizado não pode compatibilizar-se com descrições naturalistas da mente, ou com uma visão relativista da verdade, do ponto de vista contextual.

$\mathrm{Na}$ parte final, o quinto aspecto a ser exposto tenciona apontar as soluções teóricas alcançadas por Putnam por meio do conceito epistemológico de razão pragmatista. No sexto e sétimo tópicos, por fim, observará que a influência aristotélica conduz Putnam a levantar alegações acerca da objetividade dos valores, ao mesmo tempo em que estas alegações repercutem logicamente na oposição às descrições não-cognitivistas. (2008b, p. 80).

\subsubsection{Kant e Putnam}

A teoria do conhecimento de Kant está compreendida, em sua generalidade, em se deslocar do dogmatismo pela via cética sem que, no entanto, o ceticismo seja o ponto final do périplo investigativo. A tentativa kantiana é valer-se do ceticismo a fim de descortinar o caráter transcendental do entendimento para chegarmos, enfim, a um uso dogmático desse. 
Para Habermas, Putnam compartilha desta configuração geral kantiana, que é também um problema epistêmico de demarcação, ao dirigir sua crítica tanto ao ceticismo quanto ao dogmatismo. O dogmatismo está corporificado no realismo tradicional. O ceticismo está objetivado na figura dos empiristas, em face de suas constatações céticas sobre o mundo.

O ceticismo que Putnam enfrenta, no entender de Habermas, está travestido em relativismo cultural, bem como nas consequências que estão por ele alinhavadas no que diz respeito aos compromissos da teoria da ciência cum naturalismo que tem grassado no meio analítico (especificamente os mais vinculados à herança positivista). Essa teoria da ciência, assim qualificada, mantém relações internas com uma metafísica minimalista, pois tenta abandonar o suporte metafísico clássico que garantiria a correspondência imediatizada com o mundo, mas almeja, ao mesmo tempo, manter uma relação correspondencial com a realidade.

Com isto, assume posições que, para Putnam, são valorativas, ainda que estejam convenientemente ignoradas. Habermas demonstra um argumento em que Putnam nos exporia isto: (1) A justificação é uma questão de aceitar uma ou outra proposta (que será, sempre, convencional, segundo um grau de confirmação). (2) Essas propostas pressupõem valores, quaisquer que elas sejam. (3) Não é possível avaliar quais propostas positivistas são melhores, ou seja, quais valores devemos usar para justificar nossas afirmações, de modo que, em última instância, nossas escolhas estão baseadas em fins aleatoriamente almejados. Logo, as concepções positivistas são uma expressão de escolha subjetiva norteada por fins, que são, ademais, organizadas em uma linguagem científica, com o escopo de atender a certos fins, como a predição $(2008 \text { b, p. } 82)^{61}$.

\subsubsection{Realismo pós-metafísico (realismo interno), segundo Habermas}

Habermas nos oferece uma descrição muito própria do realismo professado por Putnam até o final da década de 1980, até mesmo utilizando o jargão constante em suas reflexões para designar o que, para ele, Putnam tem dito sobre o realismo. Para Habermas, na teoria do conhecimento de Putnam estão intrincadas a linguagem e a realidade de modo indesvencilhavel. Porém, não há aqui uma limitação a partir dessa relação, como se a linguagem obnubilasse nosso acesso à realidade.

\footnotetext{
${ }^{61}$ Habermas faz referência a um argumento constante no texto Why Is a Philosopher, publicado originalmente em 1986, e que integra o livro Realism with a Humam Face, publicado em 1990. Este livro recebeu uma versão em língua portuguesa, publicada pela editora Piaget, de Portugal, cujo título é $O$ realismo de rosto humano. Esse texto de 1986 foi traduzido para Por que razão um filósofo é?.
} 
$\mathrm{Na}$ verdade, a linguagem proporciona um modo de acesso ao mundo que não seria possível caso nós não a tivéssemos, de modo que podemos conceber um mundo muito mais rico através da linguagem do que aquele que teríamos se ela nos faltasse. Isso porque a linguagem, como modo de acesso ao mundo, possibilita uma concepção da realidade que não nos estaria disponível se somente nos limitássemos a representar o mundo de forma extralinguística. A linguagem é um componente não só importante, mas também condicionante de nossa ontologia básica para representar o mundo. (2008b, pp. 82-83).

Na versão do realismo tradicional há uma suposição quanto ao acesso a um mundo não interpretado, no qual se pode penetrar diretamente, sem mediações. Habermas caracteriza esta perspectiva tradicional como tendo os seguintes apanágios: 1) afirma um mundo ontologicamente "fixo e concluído"; 2) o modelo do que podemos conhecer está baseado no pensamento que representa o mundo; 3) sua noção de verdade é a "verdade por correspondência”.

Uma vez que nossa condição ontológica nos impede de capturar o mundo por outro modo que não esteja amparado pelos nossos conceitos, não poderemos, segundo a compreensão habermasiana, nos situar em um ambiente representacionalista destituído de elementos mínimos de subjetividade. Conquanto ser-nos possível revisar os conceitos que temos, não será imaginável uma forma de sairmos da linguagem para representar o mundo, concluindo-se, assim, que nossa ontologia está fundamentada nos conceitos formados na linguagem (2008, p. 83).

Tal noção nos colocaria em uma situação na qual não estaríamos habilitados a cotejar nossos enunciados e os "fatos" do mundo com o fim de afirmar que entre eles há uma correspondência perfeitamente acoplada e simétrica. Nessa esteira, acompanha-nos a noção baldada de que o mundo causa as nossas representações, de tal modo que o sujeito cognoscente o representa em sua mente como se esta imagem representada fosse a cópia provocada pelos objetos da realidade ${ }^{62}$.

Habermas interpreta que Putnam se opõe a uma visão de mundo na qual os fatos já estão desde sempre dados, são independentes de nossos conceitos e afiguram-se a nós de modo tal que deles só poderíamos ter uma versão unívoca, e ampara-se em uma importante afirmação de Putnam:

\footnotetext{
${ }^{62}$ Uma metáfora sempre a nós repetida, segundo a qual há um 'livro da natureza', cuja linguagem própria precisa ser desvendada por nós para alcançarmos sua compreensão exata, está, com o que foi dito acima, embargada, bem como a verdade por correspondência e a versão representacionalista do conhecimento. Habermas tenta corroborar esta interpretação citando Putnam: "Não existe tal coisa como a linguagem própria do mundo; só há linguagens que nós, os usuários da linguagem, inventamos para nossos diversos propósitos" (PUTNAM, 1999, p. 49 apud HABERMAS, 2008b, p.83).
} 
Não temos noções da "existência" de coisas ou da "verdade" dos enunciados que sejam independentes das versões que construímos e dos procedimentos e práticas que dão sentido a nosso falar acerca da "existência" e "verdade" dentro daquelas versões. (PUTNAM, 1983, p. 230 apud HABERMAS, 2008b, pp. 83-84).

Com esta afirmação, Putnam deixa clara sua posição, à época, acerca do realismo metafísico. Para Habermas, isso supõe a concepção de um transcendentalismo linguístico, ou seja, uma competência linguística que presume a competência para alcançarmos descrições inteligíveis de mundo. Todavia, neste ponto distancia-se de Kant, pois esta sua noção não pressupõe a ideia cética de coisa em si.

\subsubsection{Objetividade e Naturalismo Mental}

Afirma Habermas que as condições necessárias da objetividade, no que concerne aos juízos e às experiências, sofrem uma substancial alteração transcendental a partir da virada linguística ${ }^{63}$. A transcendência fica caracterizada pela capacidade que os sujeitos têm de fala e de ação que, estão, por sua vez, desde sempre na base de nossas relações sociais e culturais, além de assumirem papel central com relação a nossa objetivação do mundo.

Os sujeitos cognoscentes, que são falantes competentes, são participantes do mundo, o que significa que estão ativamente engajados na tarefa de interpretar linguisticamente esse mundo a partir do caráter transcendental da constituição dos objetos ${ }^{64}$. Esses falantes competentes são agentes racionais que estão imersos em uma situação ontológica na qual têm que forçosamente debater-se com as contingências do mundo que se lhe apresenta.

Simultaneamente, a capacidade que há de iniciarmo-nos em processos de aprendizagem e lançar novas interpretações corroboram a reconfiguração da linguagem formada e sua aplicação a contextos determinados. Para Habermas, o transcendental não é mais uma noção apartada do mundo das práticas cotidianas, estando presente em nossas práticas linguísticas comunitárias. Esta corporificação do transcendental, por meio da linguagem, tem como consequência a falta de nitidez antes visualizada na distinção clássica entre o mundo inteligível e o mundo aparente. Porém, a antiga distinção entre o inteligível e a

\footnotetext{
${ }^{63}$ Segundo Guido Imaguire e Matthias Schirn, a virada linguística "iniciou-se no final do século XIX, em particular com a obra de Gottlob Frege (1848-1925), e se estabeleceu de modo irretroativo durante todo o século XX" e que "representou uma reorientação metodológica: questões clássicas da lógica, da ontologia e da epistemologia passaram a ser tratadas por meio do procedimento de análise semântica, sintática e, um pouco mais tarde pragmática da linguagem" (IMAGUIRE \& SCHIRN, 2008, p. 9).

${ }^{64}$ Certamente Habermas já tem em mente uma alternância da transcendência kantiana para uma transcendência pós-virada linguística.
} 
aparência ressurge em sua acepção destranscendentalizada sob o aspecto da linguagem (2008b, p. 85).

Segundo Habermas (2008b, p. 85), o mundo da vida, no qual estão desde sempre os sujeitos que são capazes de fala e de ação, e o mundo objetivo, onde estão estes sujeitos, e no qual podem, por meio da linguagem e da ação, intervir e se comunicar, não são mundos que estão equiparados. Para esse filósofo, a normatividade é parte do mundo da vida, e não do mundo objetivo, de modo que, se nos deslocarmos daquele para esse, perderemos a capacidade normativa com relação ao mundo.

O componente intencional das referências aos objetos do mundo está amparado na intersubjetividade compartilhada entre os agentes falantes. Afastarmo-nos do mundo da vida para chegarmos a observar o mundo objetivo colocará, assim, um obstáculo à compreensão semântica da realidade, pois esta compreensão, que é o sentido que nos aponta e nos conecta às referências (objetos do mundo), está circunscrita aos seres racionais que compartilham uma gramática social que é utilizada no trato linguístico com o mundo objetivo. Desta forma, para Habermas, a dimensão do mundo da vida é inevitável: não há meio de nos referirmos ao mundo objetivo sem que seja a partir dele (2008b, p. 85).

Putnam, de acordo com Habermas, tem uma posição segundo a qual a linguagem, uma vez objetivada, priva-nos de sua dimensão semântica, ou melhor: no trato cotidiano da linguagem somos autorreferenciais, utilizando o suporte semântico corrente para a elucidação de si mesmo, não sendo ultrapassável esta limitação ainda que a objetivemos. Não poderíamos, desta forma, descrever palavras, em sua acepção semântica, sem nos referirmos a conceitos que estão no interior do jogo linguístico em questão, sendo impossível uma referência metalinguística a eles.

Esta atitude também é válida para as operações relacionadas à mente humana. Tanto a gramática do jogo linguístico quanto a gramática das expressões e procedimentos mentais estão normatizadas (por isso mesmo são gramaticais), sendo necessário, portanto, necessário um vocabulário que explicite a normatização e traduza os procedimentos envolvidos em uma linguagem compreensível. Habermas conclui, com isso, que não é possível naturalizar a razão, coisa que a destituiria do seu componente linguístico. 


\subsubsection{A Relativização a Partir do Contexto}

A virada linguística proporcionou, como já foi dito, uma espécie de destranscendentalização, do ponto de vista platônico, porém, colocou-nos em um horizonte compartilhável, a partir da comunicabilidade peculiar a seres racionais. Isso pode ser compreendido como uma nova maneira de compreender o transcendental por meio da linguagem. Habermas afirma que incompreensibilidade e ausência de sentido 'para nós', parte de uma referência 'nós', cujo conjunto é formado por todos os seres racionais. O 'nós', usado seja para referir-se a um objeto que é compreensível ou não, está fundamentado na capacidade de os membros de uma comunidade poderem justificar mutuamente seus discursos com relação a esses objetos. O sentido a eles atribuído não é, destarte, produto de solipsismo (2008b, p. 87).

Os critérios para a justificação estão pressupostos, assim, em argumentos racionais que os indivíduos colocarão a prova do escrutínio público de outros indivíduos racionais. Todavia, nesta abordagem habermasiana coloca-se o questionamento em que o problema principal é saber se esta razão é unívoca, ou seja, se todas as diferentes culturas a partilham, ou se ela tem uma expressividade idiossincrática em ambientes culturais diferentes. Habermas considera que a postura de Putnam está de acordo com o kantismo desse.

Por isso mesmo, ao considerar a incomensurabilidade kuhniana ${ }^{65}$ (ou ao menos sua versão original), não concorda com essa no sentido que haja uma intransponibilidade interpretativa inerente aos diversos paradigmas ${ }^{66}$. O desacordo ampara-se no argumento de Putnam, no qual a racionalidade e a justificação estão pressupostas nos paradigmas antes de sua criação, e que não há um paradigma que subsidie a racionalidade e a justificação em

\footnotetext{
${ }^{65}$ Segundo o conceito de incomensurabilidade, "as partes em tais debates (escolhas de teorias) inevitavelmente veem de maneira distinta certas situações experimentais ou de observação e que ambas têm acesso. Já que os vocabulários com os quais discutem tais situações consistem predominantemente dos mesmos termos, as partes devem estar vinculando esses termos de modo diferente à natureza, o que torna sua comunicação inevitavelmente parcial. Consequentemente, a superioridade de uma teoria sobre outra não pode ser demonstrada por meio de uma discussão. Insisti (Thomas Kuhn), em vez disso na necessidade de cada partido tentar convencer através da persuasão" (KUHN, 2013, p.309). Putnam diz que discursos incomensuráveis são "discursos que representam conceitos e conteúdos que não podemos compreender completamente por estarmos aprisionados no nosso próprio discurso e no nosso quadro conceptual” (PUTNAM, 1999, p.197) Ainda segundo Putnam, "não só os conceitos dos cientistas que trabalham com diferentes paradigmas, mas.também os objetos aos quais eles se referem, são supostamente incomensuráveis. Os astrónomos Copérnico e Ptolomeu 'habitam mundos diferentes', diz-nos Kuhn. Saltam de um paradigma para outro" (1999, p.198) de tal modo que não poderíamos compreender ao fazer-nos entender totalmente.

${ }^{66}$ Segundo Simon Blackburn, "Kuhn propõe que certos estudos científicos, como os Principia de Newton ou o New System of Chemical Philosophy, de John Dalton, sejam encarados como algo que fornece um conjunto aberto de recursos - um quadro conceitual, resultados e processos - no interior do qual se estrutura a atividade científica subsequente, A ciência normal funciona dentro deste quadro ou paradigma. Um paradigma não impõe uma perspectiva rígida ou mecânica, podendo ser entendido com maior ou menor criatividade e flexibilidade, Esse conceito teve grande influência na concepção positivista da ciência, vista como um conjunto abstrato de proposições, estruturado lógica e racionalmente. O ponto de vista de Kuhn sublinha a situação histórica concreta de uma ciência no espaço dos problemas e das perspectivas herdadas de avanços anteriores. Um paradigma é estabelecido apenas em períodos de ciência revolucionária, surgindo tipicamente em resposta a uma acumulação de anomalias e dificuldades que não podem ser resolvidas no paradigma vigente" (BLACKBURN, 1997, p.279). Mais indicações podem ser encontradas no texto de Ian Hacking, e que constitui um ensaio introdutório à obra de Thomas Kuhn arrolada na bibliografia deste trabalho. Kuhn escreveu um posfácio em 1969, como o objetivo de esclarecer alguns equívocos advindos de interpretações equivocadas do seu conceito de paradigma (KUHN, 2013, p.281-300). No próprio texto de Kuhn, o desenvolvimento desse conceito pode ser encontrado no capítulo 4 da edição já citada.
} 
questão, ou em outras palavras: a racionalidade e a justificação envolvidas no processo criativo atinente à criação de paradigmas são, elas mesmas, a-paradigmáticas. (PUTNAM, 1999a, 197-202).

Portanto, Putnam conclui que se há algo na formação dos paradigmas que não é paradigmático, pode haver um trânsito entre significados de conceitos que estão posicionados em vocabulários referentes a paradigmas específicos. Segue-se que algo melhor pode ser considerado, qual seja, a descrição estrutural das descrições (1999, p.202).

A nova forma de contextualismo, com a qual, segundo Habermas, Putnam se debate, surge na afirmação dos discursos científicos que estão sujeitos à imprecisão da linguagem formada no interior do mundo da vida. Não há uma linguagem do mundo que esteja no mundo, da qual possamos nos apropriar para criar os nossos discursos científicos. Assim, estamos presos ao ponto de vista do contexto, no qual nossos discursos estão envolvidos, do qual não podemos nos desvencilhar. Esta é a alegação que tem como consequência relativizar (inclusive) o vocabulário científico a partir do contexto. O contextualismo deste tipo também é chamado de etnocentrismo metodológico, cujas características principais foram já citadas: dependência da cultura na formação do vocabulário especial da ciência e inclusão de um vocabulário auxiliar que não segue necessariamente os critérios de racionalidade prescritos à ciência.

Putnam refuta, segundo Habermas, essas duas afirmações com a seguinte resposta. Não há, como está supracitado, incomensurabilidade, ou seja, não podemos supor que a interpretação está vedada unicamente porque certos vocabulários estão circunscritos a mundos culturais distintos: temos elementos que podem perpassar estes mundos. Se a resposta de Putnam a Kuhn visa a esclarecer um meio de superar a incomensurabilidade com o uso de elementos não paradigmáticos que podem apoiar uma descrição estrutural das descrições, na resposta ao etnocentrismo metodológico Putnam irá nos prestar uma variação dessa mesma resposta.

Segundo ele, somente podemos falar de correto ou incorreto no interior de uma cultura. Isso está de acordo com os contextualistas, mas as consequências são outras. A conclusão do contextualista convoca um condicionamento cultural intransponível, de onde faz seguir que todos os nossos discursos estão comprometidos com estes condicionamentos culturais. 
Putnam irá entender o ambiente cultural de modo distinto: estamos em um mundo cultural específico, situação essa inultrapassável; mas o condicionamento ao qual podemos estar sujeitos não o é, e temos elementos na nossa própria cultura para realizar esse passo: a crítica à tradição por meio da racionalidade ${ }^{67}$. A nossa herança cultural pode ser objeto de reflexão da nossa racionalidade e, no caso de conflitos com diversos mundos da vida, temos a mesma solução pragmática que nos livra do relativismo solipsista. (HABERMAS, 2008b, p.89).

Habermas ensina que os critérios pragmáticos exigem que estejamos prontos para assumir a perspectiva do outro, bem como a adoção do realismo e de pressupostos lógicos, como a consistência, por exemplo. Esta é plataforma que pode ser entendida como um espaço de compreensão mútua, onde os interlocutores irão desenvolver um vocabulário que viabilize o entendimento.

\subsubsection{O Conceito de Razão Pragmatista}

Uma característica fundamental do pragmatismo é, segundo Habermas, o funcionamento particular da investigação baseada na cooperação social. Por causa disto, diznos que Putnam concebe as filosofias prática e teórica em continuidade. Pois essa continuidade está amparada na convicção de que o modo especial de racionalidade, concebido a partir da atividade cooperativa, está tanto no interior do desenvolvimento da investigação científica quanto nos aspectos mais cotidianos da cooperação. Assim, pode-se afirmar que o essencial da investigação científica, compreendida pragmaticamente, é também o essencial das atividades cooperativas tematizadas em filosofia prática (2008b, p. 89).

Tratada desta maneira, a racionalidade científica não mais determina o que é racional e o que não é racional a partir dos critérios de seu funcionamento interno. Pode-se asseverar, com Habermas, que "os discursos que são não-científicos, no sentido estrito da ciência experimental nomológica, não são, por si, acientíficos.” (2008b, p.89). Apesar de, dentro desta conjuntura, as ciências serem tomadas como conhecimento, há o entendimento de que elas não esgotam o conhecimento humano com os seus próprios recursos e, mais ainda, não conseguem dar explicações sobre a razão pela qual seus procedimentos desembocam, como por elas é alegado, em um conhecimento objetivo.

\footnotetext{
${ }^{67}$ Este argumento de Putnam encontra-se na obra Realism and Reason, no capítulo Why Reason can 't be naturalized, página 234.
} 
Sobre isto poderíamos dizer que a ciência, quando procura dar razões acerca de sua própria atividade, no que concerne ao desiderato de objetividade, não a fundamenta pelos meios típicos dos procedimentos que resultam no conhecimento científico: a ciência não poderia, por exemplo, dar uma prova científica que explicasse por que seus resultados têm o status de objetivos; ao contrário, as explicações sobre as bases científicas requerem uma explicação adicional externa que não é, prima facie, científica. Esse é um claro exemplo da aventada continuidade.

Quando Putnam afirma que a ciência é incompleta, sua abordagem consiste em tomar a razão em sua acepção essencial prática (configuração baseada na interpretação de Putnam na distinção kantiana entre entendimento e razão). O eixo principal do argumento de Putnam sobre a incompletude da ciência é, para Habermas, o que aponta a ausência de consciência de que a prática científica está repleta de valores que a formam, o que o leva a dizer que "sem valores não teríamos um mundo" (1999, p. 215). A razão é prática, por isso a epistemologia estará incompleta se não incluir a ética.

A investigação científica está direcionada para alcançar a verdade e a objetividade. Este anelo exige um funcionamento peculiar para que o objetivo seja logrado ou, na linguagem de Habermas, há uma "busca estruturada normativamente" que possibilita que tal desejo de objetividade e verdade seja conseguido. Essa estrutura não escapa ao condicionamento de acoplar em sua configuração valores que lhe são originalmente extrínsecos: coerência, simplicidade, elegância são alguns exemplos de valores que se tornam intrínsecos a este funcionamento.

Habermas alega que não há, no entender de Putnam, uma diferença qualitativa entre os valores utilizados como "guias de ação" da investigação científica e os valores que temos chamados de éticos. A inevitável pergunta que Habermas faz com Putnam é: os valores que regulam o comportamento da investigação científica não ameaçaram nunca sua pretensão de objetividade. Por que no caso da ética os valores análogos geram os problemas que temos considerado com respeito à sua objetividade? (2008b, p. 91).

\subsubsection{A Colocação do Problema Acerca da Objetividade dos Valores}

Nesse ponto, Habermas começa a análise da posição de Putnam afirmando que a validade, de tipo epistemológico, que tem sido usada por esse para apoiar os juízos empíricos e, consequentemente, nos assegurar a objetividade envolvida, aplica-se aos juízos em geral e 
pelas mesmas razões, quais sejam, o mundo é o guia da verdade. Isso significa que o status ontológico daqueles juízos de fato está garantido pelo próprio mundo, em sua relação $\operatorname{conosco}^{68}$.

Fatos e valores não seriam, deste modo, tão distintos assim: ao avaliarmos os juízos de fato e os juízos de valor poderemos verificar que ambos estão amparados por uma relação com um mundo, de onde formam sua objetividade. Mas isso está longe de ser óbvio, pois em geral os filósofos são da opinião de que somente os juízos de fato relacionam-se com o mundo, enquanto que os juízos de valor se relacionam com um tipo especial de mundo, o mundo da cultura, o que lhes confere uma validade distinta. (2008b, p. 93-94).

A expectativa geral é que sigamos a distinção clássica entre fatos e valores e que demos a também clássica solução kantiana de repartir a razão pura entre prática e teórica. Assim temos a seguinte configuração: os juízos morais são explicados por uma razão circunscrita ao uso prático da razão pura, o que garante uma espécie de validade especial a juízos éticos e sua pretensão de universalidade. Esta razão prática está norteada pela vontade dos sujeitos envolvidos no trato com o mundo, representando, desta maneira, o desejo geral consignado pela forma do imperativo categórico.

Tal objetividade não pode sequer fundamentar o direito natural, pois seu estado ontológico não tem a objetividade corroborada pelo mundo físico, espécie de objetividade achada na experiência que baseia os enunciados empíricos. Chegamos ao entendimento de que os juízos de valor, dentro desta configuração conceitual, só podem receber o tipo de objetividade (a) prestado pelo reconhecimento mútuo dos interesses comunais situados em um mundo da vida compartilhado; (b) medido pelo reconhecimento das normas como fins, e não de sua relação com o mundo.

Putnam rechaça este enquadramento deontológico por vários motivos. Primeiro, não concorda com a divisão impetrada pelo sistema kantiano entre dever e inclinação, algo que ofusca o que toma como componente exigível dos valores éticos enquanto tais. Se os valores morais são aqueles que seguem o critério de universalização, então a distinção de Kant nos conduz a uma compreensão naturalista dessa espécie de valores, algo que Putnam, como vimos juntamente com Habermas, recusa.

\footnotetext{
${ }^{68}$ Lembramos que uma simples relação de causalidade não é suficiente para nos esclarecer qual o significado da 'verdade' nos diferentes casos específicos. Temos que ter uma compreensão semântica do mundo, como já foi dito. A afirmação de Putnam "Uma verdade digna deste nome tem que estar guiada pelo mundo" está em Word and Life, p. 170.
} 
Essa recusa se aplica ao empirismo, em sua abordagem não-cognitivista da moralidade, pelo qual assume a redução da moralidade a inclinações, desconsiderando o suporte valorativo que subjaz aos enunciados éticos. Para Habermas, Putnam fundamenta o valor de verdade dos enunciados éticos no realismo pragmatista, que não deixa dúvidas quanto ao caráter contínuo entre as razões teórica e prática, de modo que os aspectos deontológicos kantianos não poderiam ser tomados em sua distinção estanque, que impede conceder à moralidade a objetividade dos enunciados empíricos (2008b, p. 93).

A necessidade de continuidade está suposta na interpretação putnamiana dos conceitos éticos espessos. Neles, palavras como "cruel" e "casto", por exemplo, são a uma só vez descritivas, característica percebida em sua forma gramatical de exposição e compreensão, e avaliativas, pois não há modo de nos furtamos de assumir uma postura moral, ainda que a descrição seja neutra. A linguagem moral apresenta uma gramática que está situada no jogo wittgensteineano $^{69}$, que pode estar visível na apresentação do vocabulário com valores inerentes à sua descrição, e à composição normativa inserida pelo uso cotidiano de tal vocabulário no trato prático cultural.

Habermas, no entanto, não está convencido de que isso é suficiente para responder o grave problema que está insinuado. Em que medida são objetivos estes valores que têm um reconhecimento até aqui intersubjetivo, interpretados dentro da gramática cultural que gera a compreensão de seu significado? Deverá ser possível extravasar esta objetividade para uma esfera mais larga que a cultural ao respondermos a pergunta hipotética que Habermas faz por Putnam: "como podemos acreditar em uma linguagem carregada valorativamente se não o for, de uma maneira análoga à da linguagem empírica, ‘pela realidade’?” (2008, p.94).

\subsubsection{As Três Considerações em Favor da Validade dos Juízos Valorativos}

A primeira consideração, conforme veremos, já foi apresentada parcialmente por Habermas. Não há uma posição científica neutra do ponto de vista dos valores. Isso não significa que a ciência seja relativa aos valores, mas que no seu funcionamento interno estão pressupostos valores. Como ela não pode elidi-los sem abster-se das pretensões que lhe dão a razão de ser, conclui-se que não há neutralidade com relação aos valores, o que pode significar que os valores que mais bem correspondam às pretensões científicas serão preconizados. De igual modo, não há neutralidade na esfera dos valores éticos, e neste caso o

\footnotetext{
${ }^{69} \mathrm{O}$ conceito wittgensteineano de jogos de linguagem é notória e amplamente desenvolvido na obra Investigações Filosóficas, arrolada na bibliografia deste trabalho.
} 
argumento é muito semelhante, pois às pretensões da moralidade estão pressupostas, de igual modo, uma série de valores, sem os quais a própria moralidade não existiria.

Segundo Habermas, para defender isso, Putnam primeiro tem que empreender a demonstração de que há uma continuidade entre valores cognitivos e não cognitivos, ou melhor, que os valores até aqui considerados não cognitivos são valores cognitivos. A característica principal dos valores chamados de cognitivos é a assertividade que pode designar um valor de verdade, ao passo que não podem fazê-lo outras espécies de valores. Putnam afasta esta crítica com a suposição de que o conceito de verdade utilizado é uma imagem sincopada da teoria da verdade por correspondência. Ora, se o projeto de Putnam visa a demonstrar que o realismo tradicional está equivocado em pontos fulcrais, podemos incluir em seu bojo sua versão da verdade, qual seja, a teoria da verdade por correspondência. Desta feita, essa verdade não seria outra coisa que um valor utilizado epistemicamente, por exemplo, pelo positivismo lógico.

A segunda consideração de Putnam também enunciada por Habermas (2008b, p. 95), diz respeito ao pluralismo ético e o pluralismo de visões de mundo. Há, no que concerne aos enunciados sistemáticos da experiência, uma expectativa de que eles possam convergir, conquanto isso não seja esperado na ética. Putnam entende, assim, o pluralismo ético e suas consequências, sem que, no entanto, isso o conduza ao ceticismo de cunho moral.

No entanto, não podemos afirmar que a característica de divergência observada na pluralidade de expressões culturais no âmbito moral seja uma prerrogativa da ética. De igual modo, não estaríamos racionalmente habilitados a alegar que a ciência caminha para uma convergência de seus enunciados, de modo a formar uma "imagem teórica definitiva". (PUTNAM, 1999, p. 237) Isso é importante na perspectiva da crítica de uma pré-concepção utópica: a de que a ciência caminha para a total unificação sistemática dos enunciados que figuram nas diversas teorias existentes; enquanto que a ética, ou as teorias éticas de até então, representam a adequação de enunciados não-cognitivos aos desejos coletivos comunitariamente compartilhados.

Mas Habermas critica esta postura e a julga um tanto inócua, pois, segundo ele, as ciências de modo algum anelam por convergência e, ademais, sugere que a imagem do realismo putnamiano que emprega argumentos torna a incomensurabilidade uma ficção relativista. De modo que Habermas parece nos apontar que a tradutibilidade constante nos argumentos anti-incomensurabilistas de Putnam dispensaria a suposição utópica da ciência que vislumbra uma unificação possível no futuro. (2008b, p. 96). 
O pluralismo das visões de mundo funciona, obtempera Habermas, de modo a estruturar a totalidade da vida. Podemos esperar que o desacordo seja parte integrante da multiplicidade das perspectivas, e igualmente devemos supor que estamos amparados pela razão ao admitirmos a razoabilidade desses desacordos, expediente que obstará as formas de vidas plurais de quererem eliminar-se mutuamente por meio da dissuasão irracional. (2008b, p.96)

A terceira consideração é atinente ao relativismo forte, no qual as culturas têm suas normas e seus valores éticos estatuídos segundo conceitos éticos espessos forjados em seu interior. Não obstante a origem cultural desses valores, e sua normatização consecutivamente intersubjetivada, Putnam nos assegura que o vocabulário que usamos pra expressar conceitos éticos abstratos está de acordo com uma linguagem avaliativa.

Concorda Habermas com Putnam que o tipo de gramática subjacente a estes conceitos aproxima as diversas culturas, de modo que se pode legitimamente fazer julgamentos de valor a casos culturais específicos que distam bastante de nós, como por exemplo, reprochar os sacrifícios humanos operados pelos astecas. Embora as condições de eclosão dos valores éticos espessos sejam culturais, Habermas afirma (2008b, p.97) que Putnam solapa a distinção valores locais/valores universais, pois está pressuposta no tipo espesso do vocabulário a sua tradutibilidade cultural, assumindo, assim, o aspecto gramatical universalmente compreensível e interpretável.

\subsection{Putnam Retorque a Habermas}

Hilary Putnam retoma os esclarecimentos acerca de sua posição a partir das críticas interpretações que são perpetradas por Jürgen Habermas. Ao fazê-lo, relembra-nos dos principais pontos que foram considerados no tocante à ética do discurso, passo crítico que deu ensejo para que Putnam iniciasse a exposição de sua postura com relação à objetividade dos valores, tendo como motivação motora a discussão da dicotomia normas/valores. Esta rememoração pontua o cerne da crítica de Putnam: 1) "nossa capacidade imperfeita, mas indefinidamente aperfeiçoável, de reconhecer as demandas que nos aproximam diferentes valores é precisamente o que dota de conteúdo a ética kantiana (ou a ética do discurso)"; 2) "Não há razão para crer que o resultado de uma discussão ideal e suficientemente prolongada das questões éticas sejam inevitavelmente corretas"; 3) "A situação ideal de fala é vazia pela ausência de conceitos éticos espessos" (PUTNAM, 2008b, pp. 108-109). 
A referência ao vocabulário ético espesso tenciona demonstrar que, por um lado, temos em nossa linguagem uma atribuição de conteúdo que se alimenta de casos que nos são externos, por isso podemos descrevê-los rigorosamente, o que nos impossibilita de prestar, antecipadamente, uma configuração meramente formal aos nossos juízos de valores. Por outro lado, se esse vocabulário só pode ser considerado válido em uma comunidade específica, ou seja, se ele somente for relativo a um contexto cultural, poderíamos visualizar uma precisa universalidade formal, conquanto as normas careceriam de um conteúdo que fosse formal.

Por esse motivo, Habermas atribui a Putnam uma posição que esse rejeita, apesar de reconhecer o esmero e esforço que Habermas empreendeu ao analisar sua obra. Desde o início de sua resposta, Putnam revela-nos que Habermas supõe uma série de ideias professadas por Putnam sem que esse, no entanto, realmente as professe. E, a partir desta suposição, recoloca o problema putnamiano a partir destas considerações.

Segundo Putnam, as atribuições equivocadas são a suposições: 1) de que existe uma mesma validade para enunciados empíricos e éticos; 2) que "verdadeiro" é o nome com o qual podemos classificar esta espécie de validez; e 3) que o conjunto de enunciados éticos tem esta validez, sejam eles normativos ou juízos de valor. As afirmações habermasianas fazem enquadrar Putnam em um realismo moral que não diferencia a validade empírica da validade ética. Nossa intenção será, a partir de agora, expor pormenorizadamente a resposta que Putnam lhe presta. .

\subsubsection{A Explicação de Putnam sobre sua Posição}

A estratégia que Putnam assume é rebater uma a uma, as três atribuições de Habermas. Comecemos, portanto, com a enunciação da primeira:

1) "Todos os enunciados empíricos corretos têm um e mesmo tipo de validade" (PUTNAM, 2008b, p. 111).

Com relação aos enunciados empíricos, Putnam declara que esses não são enunciados de uma mesma categoria harmoniosa e não se dirigem do mesmo modo à realidade. Assim, partindo da crença de que os enunciados empíricos são fiáveis, não é racional coadunar-se à ideia de que esses enunciados são válidos por adotarem o mesmo modo de validade (embora sejam ambos válidos). 
Aqui é importante destacar o esclarecimento que Putnam propõe para a acepção em que usa a locução "enunciados empíricos". Segundo ele, essa locução é utilizada de forma ampla, e são enunciados que designam coisas, ocasiões específicas, eventualidades, etc. Porém, Putnam diz-nos que assim como "Wittgenstein e James, não pensa que 'referir-se a', 'denotar', 'extensão' e outros termos deste tipo estão no lugar de uma e mesma relação entre um termo e as coisas que o 'correspondem' em cada caso concreto" (2008b, p. 112). Existem "acordos" e "métodos de projeção" 70 que alteram o modo de nossa referência às coisas. Podemos nos referir ao amor dos gregos pelo teatro, referir-nos a um sofá, referir-nos à humildade de fulano, e todas essas referências serão distintas entre $\mathrm{si}^{71}$.

Outrossim, nesta definição, os enunciados empíricos são todos corrigíveis, ou pelo menos uma grande parte desses enunciados. Putnam vê dificuldades em pensar que o enunciado "a água já entrou em ebulição ao menos uma vez na história do mundo" possa ser um enunciado corrigível como "a água já entrou em ebulição ao menos uma vez nesta cozinha". Sua coleção de exemplos quer nos demonstrar que nem todos os enunciados empíricos podem ser tomados pela envolvente classificação de científico, ou mesmo podem ter-lhes fornecidos um único e mesmo tipo de prova guiado por um método unívoco, como já fora assinalado ${ }^{72}$.

Os exemplos de Wittgenstein, nos quais Putnam se inspira, apontam para a impossibilidade de aplicação do método científico para uma classe de enunciados empíricos que, por exemplo, remetem a expressões de emoção, de modo que uma frase como "João ama Maria" não pode ser submetida ao método aventado, embora se trate de um enunciado que podemos corroborar empiricamente. Temos que certa classe de enunciados empíricos não são, em última instância, científicos, inaugurando, assim, uma classe de enunciados empíricos não científicos. Putnam considera que nesse ponto Habermas se equivoca ao interpretá-lo (2008b, p. 113).

A ampliação daquilo que se tem chamado de enunciados empíricos pode gerar equívocos. Poder-se-ia tomar a frase "Em geral, os colonizadores europeus foram cruéis para com os índios" como um enunciado empírico que não é científico; conquanto a frase "Não devemos agir, decididamente, de forma cruel para com as crianças", não está incluída na classe de enunciados éticos não científicos.

\footnotetext{
${ }^{70}$ Os termos entre aspas designam a maneira como William James e Ludwig Wittgenstein referiam-se, respectivamente, a esta questão.

${ }^{71}$ Putnam presta-nos outro interessante exemplo: a referência à cor azul do céu é distinta caso eu seja um pintor ou um meteorologista (2008b, p.112).

${ }^{72}$ Neste mesmo ponto, Putnam afirma que mesmo os enunciados científicos não podem ser provados por um único método geral.
} 
Segundo Putnam, a confusão de Habermas é proveniente do uso que esse faz da palavra 'verdadeiro'. Putnam acredita que esta confusão ocorra porque ele utiliza a palavra 'verdadeiro' para todas as distintas espécies de classes de enunciados empíricos. Assim, a gama de exemplos supracitados pode ser designada por 'verdadeira' ou 'falsa' da mesma maneira que enunciados empíricos científicos o podem, todavia não segundo a aplicação dos mesmos métodos. Entretanto, é extrapolado dizer que normas também são juízos de valor, ou que a totalidade de juízos de valor são enunciados empíricos. Do mesmo modo, Habermas não poderia afirmar, caso o fizesse, que Putnam toma todos os enunciados empíricos por científicos.

Dito isso, Putnam distingue duas classe de enunciados empíricos: os não científicos e os científicos. Tal divisão funciona para tramar uma separação metafísica que dá suporte a uma inovadora utilização da palavra 'verdade': agora estamos habilitados a designar enunciados empíricos referentes a espécies não naturais. Muito contrário do que Habermas faz, ao aplicar a palavra 'verdade' somente a espécies naturais, e com isso confirmar o enquadramento metafísico clássico de sua aplicabilidade.

Termina Putnam por dizer que Habermas quer alcunhar-lhe de realista moral radical. Ao passo que ele preferiria o apelido de pluralista, de uma categoria que entende "enunciados corretos em muitas classes diferentes de jogos de linguagem" (2008b, p.113), sem que “correto" signifique o que está compartilhado no interior de uma comunidade cultural.

A segunda atribuição é enunciada da seguinte maneira:

2) “A palavra 'verdadeiro' é um nome para esse tipo de validez" (PUTNAM, 2008b, p. 111).

A esta consideração de Habermas, Putnam interpõe em resposta uma relevante consideração acerca do predicado gramatical 'verdadeiro', tal como ele tem sido tomado nas diversas posições na filosofia analítica da linguagem. Costuma-se chamar esta família de posições a que ele irá se referir pelo nome de teorias descitacionais da verdade. Putnam lembra que há três importantes vertentes da teoria descitacional da verdade: a deflacionária, que está ligada a Carnap; a vertente fregeana; e a vertente a qual se associa Putnam, qual seja, a posição do último Wittgenstein ${ }^{73}$ (2008b, p. 114).

Ao começar sua reflexão, Putnam julga ser importante relacionar primeiramente o que há de comum entre as três vertentes (2008b, p. 114). Assim, o ponto de contato entre as

\footnotetext{
${ }^{73}$ Trata-se do Wittgenstein das Investigações Filosóficas.
} 
diversas teorias descitacionais da verdade é o principio enunciado por Dummett (uma espécie de proto-esquema T), chamado de 'princípio de equivalência'. Esse princípio reza o seguinte: se temos uma frase como "é verdadeiro que a chuva é refrescante", ou "é verdadeiro que a rosa é vermelha", ou "é verdadeiro que maltratar crianças é algo errado" será equivalente aos enunciados "a chuva é refrescante", “a rosa é vermelha”, "maltratar crianças é algo errado".

Caso possamos avaliar a oração, ou para usar a linguagem técnica da lógica tarskiana, a linguagem objeto, segundo a sua verdade, de modo que diremos da oração "a rosa é vermelha", que ela, oração, é verdadeira, então poderemos enunciar do seguinte modo o princípio de equivalência, segundo o esquema $\mathrm{T}$ :

(T) “A rosa é vermelha” é verdade se, e somente se, a rosa é vermelha.

Com a alegação de que as diversas apresentações da teoria descitacional da verdade dão ênfase a algum modo do princípio de equivalência, Putnam quer dizer que os partícipes da teoria descitacional defendem a posição que:

1) Sempre que a palavra 'verdadeiro' puder ser predicada a uma frase $F$, é conveniente que o predicado seja suprimido. Frege aparentemente pensa que em alguns casos a frase "É verdade que a rosa é vermelha" e a frase "A rosa é vermelha", essa na linguagem objeto, podem representar o mesmo tipo de juízo. Ora, se a ocorrência disto for correta, então podemos afirmar que a atribuição do predicado 'verdadeiro' é desnecessária na frase "É verdade que a rosa é vermelha", bem como em todas as frases com a forma "É verdade que $F$ " (PUTNAM, 2008b, p.114). Desta maneira, dada a qualidade de desnecessário do predicado gramatical 'verdadeiro', não podemos chamar, como Habermas supõe que Putnam faz, 'verdadeiro' de um tipo de validade.

2) Ademais, há uma explicação racional para o uso de 'verdadeiro', sem precisar supor tratar-se do emprego necessário de um hipotético tipo de teoria "citacional" descritiva, ainda que não consignada pela suposta validade intrínseca ao uso de 'verdadeiro'. A razão do emprego de 'verdadeiro' advém da necessidade que temos de, na nossa linguagem, usar esta designação em proposições com a forma " $x$ é verdadeiro", proposição na qual a letra ' $x$ ' não é uma proposição, mas, antes, uma variável quantificacional.

Usando o exemplo de Putnam (2008b, p. 115), se dissermos "Uma das proposições que João escreveu na página 12 é verdadeira”, que, na linguagem simbólica do cálculo de predicados ficaria na forma: (马) (João escreveu x na página $12 \wedge \mathrm{x}$ é verdadeiro) ${ }^{74}$, podemos

74 Esta é uma notação de lógica simbólica em que '(马)’ é um quantificador existencial, enquanto que ‘ $\wedge$ ’ é uma conjunção. 
suprimir "x é verdadeiro" se, e somente se, for do nosso conhecimento que João de fato tenha escrito certas proposições na página 12. Deste modo, se João escreveu que "a chuva é refrescante", "a rosa é vermelha" e "maltratar crianças é algo errado", podemos equivaler estas proposições à proposição seguinte: “João escreveu que 'a chuva é refrescante', 'a rosa é vermelha' e 'maltratar crianças é algo errado"”. Dito de modo mais simples, a necessidade ocasional do emprego do predicado 'verdadeiro' se dá quando o usamos como uma propriedade lógica, que é a propriedade descitacional. É necessário quando usado de modo lógico, e não quando usado de modo descritivo.

Depois das elucidações atinentes aos aspectos comuns às teorias chamadas pelo nome geral de 'teoria descitacional da verdade', Putnam inicia, como fora prometido, a explicação genérica das três vertentes da teoria em questão.

Putnam inicia sua explanação genérica com uma afirmação fregeana: segundo esta posição, a 'verdade' nada mais é que um predicado aplicado aos pensamentos, e esses não são palavras. Assim, para Putnam esta posição fregeana "pressupõe uma metafísica dos 'pensamentos"” (2008b, p. 117). Se para Frege 'verdadeiro' se aplica aos pensamentos, em Tarski 'verdadeiro' é um predicado que se aplica às proposições. E, finalmente, para Wittgenstein, que tem sua posição acolhida por Putnam ${ }^{75}$, segundo o qual o:

...verdadeiro é um predicado de orações que são usadas de determinadas maneiras, isto é, um predicado de objetos que não são nem meramente sintáticos (como as proposições de Tarski) nem completamente independentes do uso dos objetos sintáticos dentro de uma particular comunidade linguística (PUTNAM, 2008b, p 116).

Putnam afirma que Habermas, ao fazer sua crítica, não toca realmente a sua posição. Isso porque considera que Putnam usa o conceito de 'verdade' em diversas acepções especializadas, tendo em vista utilizar essa diversidade conceitual em muitas aplicações específicas das várias noções ora dirigidas a normas, ora dirigidas aos enunciados empíricos, e em outra ocasião aos enunciados matemáticos. O que Putnam nos ensina (2008b, p. 116) é que uma noção de verdade que remeta a Frege e a Tarski, apesar de suas diferenças, pode nos dar justificativas suficientes para que utilizemos uma única concepção de verdade, que se aplica a enunciados epistêmicos e enunciados metafísicos distintos, pois essa noção de verdade tem uma concepção 'lógica'.

\footnotetext{
${ }^{75}$ Esta posição é desenvolvida no capítulo 3 da obra Corda Tripla, publicado no Brasil em 2008.
} 
A ocorrência disso se dá porque a concepção lógica da verdade, utilizando-se mesmo do cálculo proposicional, combina enunciados dos dois tipos, epistêmicos e metafísicos e, como é de se esperar, nos fornece a possibilidade de fazer inferências. Putnam cita um argumento em modus ponens para ilustrar o que isso quer significar:

1. Se João estudar diligentemente, tocará piano melhor.

2. João tem estudado diligentemente.

3. Logo, João toca piano melhor $(1,2)$.

Este argumento é válido, sua inferência segue-se das premissas e, apesar disso, temos a citada combinação de enunciados: o antecedente de (1) é uma proposição descritiva enquanto que o consequente de (1) é valorativo, pois se refere a um juízo de valor. A lógica fixa conexões em enunciados de qualquer origem semântica.

A terceira atribuição, a qual Putnam dedicará uma resposta bastante sucinta foi enunciada como se segue:

3) "Todos os enunciados éticos corretos têm o mesmo tipo de validade"

Putnam responde de maneira quase telegráfica, pois o argumento central para essa advertência habermasiana já consta em sua resposta à primeira atribuição: não há uma única validade para enunciados normativos e para os juízos de valor que não possuem a forma de dever universal; de modo análogo ao argumento segundo o qual não há uma validade unívoca para enunciados empíricos e enunciados científicos.

Esta confusão se dá, reflete Putnam (2008b, p.117), por causa do uso que ele faz dos valores designados 'verdadeiro' e 'falso', e de sua aplicação universal. De modo algum Putnam advoga que há uma confusão entre 'dever' e 'ser', como deixamos claro nas explicações acima, haja vista sua descrença justificada de que há uma validade capaz de abarcar, a uma só vez, o conjunto de enunciados científicos, ou o conjunto de enunciados empíricos.

Depois de todo o debate exposto, fica claro o quão complexa é a questão. Pensamos ter apresentado o direcionamento de Putnam com relação à problematização proposta. Putnam apresenta seu posicionamento sobre as normas e valores, assumindo que os valores são o esteio sobre o qual repousam as normas; rejeita a teoria pragmatista da verdade, tal como fora configurada pelo que chama de postura "Apel-Peirce"; e argumenta acerca da tendência naturalista em filosofia moral, posicionando-se contrariamente a ela. A réplica de Habermas levanta questões que a Putnam interessa refutar, o que é um aspecto revelador das posições 
com as quais veementemente não concorda, e os três pontos que elenca estão relacionados: a mesma validade para enunciados éticos e empíricos; uma noção de "verdade" que tem como função classificar tal validade; e por fim, que os enunciados éticos lato sensu têm uma única validade.

Pensamos que é ainda importante esclarecer o significado do conceito de validade e verdade discutindo com maior profundidade como essas questões têm sido tratadas por Putnam nos últimos anos. Para isso, pensamos que a chave para entendermos essas questões é o realismo interno, noção que foi desenvolvida nos anos 1980, mas cujo gérmen estava já no artigo Realismo e Razão, de 1976.

O realismo interno é a posição putnamiana segundo a qual a objetividade, bem como o conceito de verdade, recebem um tratamento novo, posterior à crítica que o século XX faz à metafísica clássica, e que, muito embora tal posicionamento crítico esteja firmado naquilo que Putnam reiteradamente diz em suas reflexões, não admite as conclusões que miríades de filósofos percebem como inevitáveis, sendo o relativismo cultural a mais grave delas nos âmbitos epistemológico e político. A resposta para o questionamento de por que Putnam defende sua posição atual, levantado ao começo desse capítulo, teve sua pedra angular lançada já no segundo capítulo, quando da crítica encetada por Putnam à metafísica tradicional, passando a defender aquilo que ele chama, ou deveria ter chamado, segundo ele mesmo afirma, de realismo pragmático (PUTNAM, 1994, p. 61). 


\section{CAPÍTULO IV: REALISMO INTERNO E RELATIVIDADE CONCEITUAL}

O objetivo deste capítulo é evidenciar que o realismo interno pode ser um arcabouço teórico capaz de garantir que haja objetividade nos contextos linguísticos que estruturam nossas inter-relações comunitárias. Isso é parte de um projeto que Putnam tem desenvolvido desde a metade da década de 1970 e que, se lograr êxito, poderá ajudar a solucionar, a uma só vez, os problemas suscitados pelo relativismo cultural e dar um encaminhamento programático no que se refere à viabilidade de compreensão da realidade social e política em que está assentado o Ocidente, no que concerne à condição irreversível do pluralismo contemporâneo. Desse modo, nosso intuito será o de deixar evidenciado que é possível haver objetividade fundamentada em uma alternativa moderada do realismo que, segundo o próprio Putnam, rejeita o realismo da metafísica tradicional e também as consequências mais comuns desse alijamento, qual seja, o relativismo cultural.

Em 1977, Hilary Putnam esboçou uma primeira formulação sucinta do que é conhecido atualmente como "realismo interno" em seu artigo intitulado Realism and Reason. Ele escreveu, em 1999, que havia chamado de 'realismo interno' a posição que defendera, tempos atrás, em seu famoso artigo The meaning of meaning, publicado originalmente em 1975, e que um sem-número de pessoas começaram a chamar esse 'realismo interno' de a nova posição de Putnam (2008c, p. 33). Ele mesmo reconheceu que a expressão era confusa, e em 1987 afirmou que deveria tê-la chamado de 'realismo pragmático' (1994, p. 61). Falaremos mais adiante sobre o motivo da confusão e porque preferimos, tal como Putnam, a nomenclatura 'realismo pragmático'.

Naquela definição originária, Putnam afirma que nessa espécie de realismo "não é a linguagem que espelha o mundo, mas que os falantes espelham o mundo" e que se trata "da relação dos falantes com seu ambiente, e do papel da linguagem" no que a isso concerne (1977, p. 483). Aqui temos algo que será amplamente desenvolvido, a saber, o papel do usuário de uma linguagem na constituição especular do mundo, e Putnam afirma que esse espelhamento tem o sentido de "construção de uma representação simbólica desse ambiente" (idem); e da relação entre mundo-falantes-linguagem, que é o tripé sobre o qual repousará essa nova visão de realismo. 
O realismo interno objeta as principais características da metafísica tradicional ${ }^{76}$, e o faz por flagrante incompatibilidade dos pressupostos que fundamentam a ambos. O realismo interno denega a correspondência exata que hipoteticamente há entre nós e o mundo. Essa correspondência exata é algo que não tem sentido para um realista interno. O sentido da correspondência unívoca entre linguagem e mundo está estruturado do seguinte modo: Para haver correspondência exata (ou unívoca) entre nosso vocabulário e o mundo, precisaríamos da possibilidade de uma linguagem ideal que pudesse se referir ao mundo tal como ele é. Caso contrário, se nossa linguagem não fosse ideal, nossas designações linguísticas sempre estariam continuamente sujeitas a aperfeiçoamentos e fora da possibilidade de se referirem de forma unívoca ao mundo e, assim, de imprecisas que seriam, não nos poderiam auxiliar a descrever o mundo corretamente.

Por conseguinte, nós deveríamos almejar não simplesmente que nossa linguagem fosse melhor, mas, para representar o mundo como é devido, deveríamos desejar que ela tivesse um poder expressivo perfeito. O mundo "tal como ele é" reúne a totalidade finita de objetos do mundo, ou como Putnam os chama, "o mobiliário do mundo". Esse "mobiliário" é composto por objetos singulares possuidores de essências e características disposicionais que, quando são descobertas, podem ser nomeadas e comunicadas.

O mundo "tal como ele é" é composto por objetos fixos. A ideia de objetos fixos presume que o mobiliário do mundo está no âmbito da possibilidade de ter a maior parte de seus objetos representados e captados por nós pelo médium linguístico. Essa estrutura do mundo "em si" pode ser conhecida pela razão e transmitida pela linguagem, pois o logos filosófico tem que ser capaz de exprimir as verdades que estão claras na razão (DE OLIVEIRA, 2006, p. 126). Isso corrobora a ideia de que um mundo pronto está disponível epistemologicamente de maneira não refratária, bastando que seus objetos sejam acessados, ou melhor, descobertos pelas vias certas.

Segundo Putnam, "Não há nenhum ponto de vista do Olho de Deus que possamos conhecer ou imaginar proveitosamente" (1992, p. 72). O que é esse ponto de vista do "Olho de Deus"? A perspectiva do "Olho de Deus" sugere a possibilidade de representarmos o mundo sem que tal representação esteja conspurcada por nossas mediações humanas que,

\footnotetext{
${ }^{76}$ A crítica a essas características foram desenvolvidas no capitulo II, na seção intitulada A Dicotomia entre Juízos de Fato e Juízos de Valor, de modo que a crítica não será reiterada nos mesmos termos. Relembremos quais são os apanágios da metafísica (ou realismo) tradicional: “existe uma totalidade de Formas, ou Universais ou 'propriedades', estabelecida de uma vez por todas, e de que todos os significados possíveis de uma palavra correspondem a uma dessas formas ou Universais ou propriedades"; "o pressuposto confortável de que há uma totalidade definida de objetos que pode ser classificada, bem como uma totalidade definida de todas as propriedades" (2008c, p. 19); há "uma nítida linha divisória entre as propriedades que 'descobrimos' no mundo e as que 'projetamos' no mundo"; há "uma relação fixa de 'correspondência' em termos da qual se supõe que a verdade seja definida” (2008, p. 35).
} 
inevitavelmente, irão produzir uma deturpação dessa perspectiva pura. É a conjectura, tornada convicção, de que uma realidade independente de nós pode ser representada na medida dessa independência, e aquém desse nós. Isso significa que se pode conceber uma relação ideal de correspondência entre os humanos e a realidade independente sem que seja levado em consideração o lugar que ocupamos na realidade independente.

A perspectiva que o realismo interno procura instaurar é um ponto de vista telúrico, no qual a visada humana possa ser privilegiada. A ênfase da perspectiva do realismo interno não está em um ponto de vista que alije o papel do humano na configuração do real, mas, pelo contrário, que o reforce. É importante notar que segundo Putnam, a perspectiva humana sobre a realidade é a única que nos está disponível (1992, p. 211).

Não há que se imaginar outro modo de percebê-la, e fazê-lo, negando a experiência da perspectiva de primeira pessoa, é estabelecer que a realidade é passível de uma compreensão neutral, a partir do "Olho de Deus", que prescinde da nossa visada humana. O Olho de Deus é o ponto de vista ideal da realidade a qual a perspectiva humana se resume a descrever, na medida que não interfere, tal como ela é. Assim, o "Olho de Deus" é a teoria da verdade única (PUTNAM, 1992, 102).

Ora, se estamos a falar que não há um ponto de vista privilegiado que nos garanta uma descrição de objetos e suas propriedades, ambos fixos, estamos a recusar um absoluto conceitual, em que está inclusa a possibilidade de descortinamento de um mundo pronto. Se não há esse ponto de vista privilegiado do mundo, como pode o realismo interno fundamentar a noção de objetividade?

Comecemos com uma afirmação de Putnam: “Se nossa 'objetividade' é objetividade humanamente falando, ainda é objetividade suficiente" (1992, p. 211). Isso quer dizer duas coisas principais. Primeiro, significa que no realismo interno há a confissão de que não detemos um ponto de vista neutral, e que o ponto de vista não-neutral é eminentemente humano. É que é a partir dessa perspectiva insuperável, o ponto de vista do agente humano, que podemos pronunciar nossas asseverações, e as marcas dessa visada humana estão em tudo aquilo que fazemos.

Segundo, quando abandonamos o ponto de vista do "Olho de Deus", isto é, a teoria da descrição unívoca, abandonamos a objetividade que a ela está articulada. Porém, não é necessário alijar a noção de objetividade, como em geral fazem aqueles que derrogam o ponto de vista do "Olho de Deus", e adotar o relativismo. Dito de outro modo, aquele que adota um 
ponto de vista diferente do apresentado pela metafísica tradicional não está fadado a abandonar o conceito de objetividade. Agora deveremos explicar como isso acontece.

Proporemos, para essa finalidade, o mesmo esclarecedor exemplo de qual Putnam se utiliza para levar adiante essa questão (2014, p. 170). Imaginemos que em uma casa entrem dois amigos, e que sua mobília aparente seja composta por uma cadeira, uma mesa e, em cima da mesa, uma lâmpada, um caderno e uma caneta. A pergunta lançada, um tanto quanto enigmaticamente por um dos dois amigos, é a seguinte: “Quantos objetos há na casa?”, ao que o outro responde prontamente "Cinco objetos, e são eles a mesa, a cadeira, a caneta, o caderno e a lâmpada".

O amigo que lançou a questão inicial prossegue: "E quanto a nós dois? Por acaso não estamos na casa?". O amigo que é interrogado responde, com surpresa: "Não sabia que você havia considerado que nós dois poderíamos ser contabilizados como objetos. Se é esse o caso, então o número total de objetos é sete”. Entretanto, o amigo não se dá por satisfeito com as duas interrogações anteriores e volta à carga com uma terceira: "E o caderno que aqui temos? As páginas que lhe compõe não são objetos?".

Putnam imagina que uma resposta a essas questões está ligada profundamente a certos pressupostos que são assumidos pelos amigos. Se adotarmos certa espécie de modo de analisarmos as questões proposta, diremos que o número de objetos é 'cinco'; se adotarmos outro modo, o número de objetos pode parecer não contabilizável. Por exemplo: se considerarmos que os átomos que estão presentes na casa são objetos, certamente haverá dificuldade no estabelecimento de quantos objetos eles existem. Poder-se-ia fundamentar a tese de que átomos são objetos se assumíssemos a premissa de que toda entidade que pode ser o valor de uma variável ligada a um quantificador, ou seja, qualquer coisa a qual possamos nos referir utilizando um pronome é um objeto. Desse modo, os referidos átomos, tomados isoladamente, seriam miríades de objetos singulares, e na casa da qual falávamos haveria muito mais do que cinco ou sete objetos.

Caso rejeitássemos essa compreensão do que é um objeto, e assumíssemos outra versão de como eles são compostos, segundo a qual tal metafísica consideraria que há certas entidades são partes de objetos que, por sua vez, são configurados a partir da conjunção dessas partes, então nem todas as entidades que pudessem ser referidas pronominalmente seriam objetos, de modo que as páginas do caderno, por exemplo, seriam partes do objeto caderno, e não objetos singulares. Dissemos acima que embora alijássemos uma "teoria da verdade única”, não extinguiríamos a noção de objetividade. Todavia, como está já 
evidenciado pela situação apresentada, a noção de objetividade de que falamos distingue-se por não poder ser independente.

Nas duas interpretações possíveis que aventamos para responder a pergunta "Quantos objetos existem na casa" o que garante uma resposta precisa é o uso que fazemos da palavra objeto (PUTNAM, 2014, p.174). É a partir do modo como entendemos os aspectos conceituais dos termos que usamos para nos referirmos as entidades que poderemos fixar alguma espécie de objetividade. Não é possível imaginar qualquer forma de objetividade na resposta a essa questão que prescinda da maneira como são aplicados os termos. A objetividade e, por consequência, a verdade dos enunciados dependem do uso dos termos. Putnam nos diz que:

... numa visão interiorista ${ }^{77}$ os signos não correspondem intrinsecamente aos objetos independentemente de como e por quem esses signos sejam empregues. Mas um signo que seja de fato empregue de um modo particular por uma comunidade particular de utentes pode corresponder a objetos particulares no interior do esquema conceitual desses utentes. Os "objetos" não existem independentemente dos esquemas conceituais. Nós retalhamos o mundo em objetos quando introduzimos um ou outro esquema de descrição (PUTNAM, 1992, p.80).

A citação acima pode esclarecer vários pontos do realismo interno. Primeiro, como já o temos dito, o uso e aplicação dos termos são condição presente para que se tenha a verdade ou a falsidade de um enunciado. A objetividade do termo necessita de um contexto no qual ele é empregado, e com isso se garante que o termo possua significado. Como Wittgenstein afirma, e Putnam parece estar de acordo, "O significado de uma palavra é seu uso na linguagem" (WITTGENSTEIN, 2009, p. 38).

Isso nos leva ao segundo ponto, a saber, o de que não há possibilidade de o uso estar desvinculado de uma comunidade de usuários de uma determinada linguagem. Ou seja, o uso ocorre no interior de um conjunto formado por termos e modos de referência que é desenvolvido ao longo das diversas situações históricas e culturais a que uma comunidade linguística pode estar submetida. Chama-se a esse cenário linguístico condicional de esquema conceitual.

Com a intrusão do conceito de "esquemas conceituais" a noção de "objeto" se aclara a partir da metáfora do molde de biscoitos: "As coisas, independentemente de toda eleição conceitual, são a massa; a forma do molde nossa contribuição conceitual" (PUTNAM, 1994, p. 174). As entidades a que chamamos de "objetos" podem ser consideradas assim não porque

\footnotetext{
${ }^{77}$ Putnam usa diversas vezes o termo 'interiorista' para designar a posição do realista interno.
} 
haja uma realidade objetual em si, mas porque nós recortamos a realidade com o fim de distinguirmos certas partes e, desse modo, podermos a elas nos referir. Por isso que Putnam afirma que não existem objetos independentes dos nossos esquemas conceituais, e aqui temos o enseja para a explicação do que é a "relatividade conceitual".

Todos os objetos são dependentes dos esquemas conceituais, isto é, seu significado está condicionado à utilização de seus termos referentes em um ambiente interno numa forma linguística sistemática ao qual tais significados são relativos. Relativo, aqui, quer dizer simplesmente que o sentido do vocabulário possui como critério de significado a sua referência no interior de um esquema conceitual, sendo que, assim, o significado de um conceito é relativo a um determinado esquema conceitual.

Nesse ponto podemos entender porque Hilary Putnam se arrepende de ter chamado sua posição de realismo interno, preferindo o nome "realismo pragmatista" (2014, p. 174). O principal motivo é a confusão criada, segundo a qual a palavra "interior", da denominação "realismo interior", tem algo a ver com uma fórmula fundamentada na subjetividade para a configuração da realidade. Destarte, a realidade seria uma convenção formada a partir da subjetividade. Putnam detecta esse equívoco, apontando o aspecto central da objetividade salvaguardado no realismo interno (ou pragmatista) aludindo ao exemplo da casa em que entram os dois amigos:

\footnotetext{
Uma vez que deixamos claro como estamos a utilizar "objeto" (ou "existe"), a pergunta "Quantos objetos existem aí?" tem uma resposta que não é de maneira nenhuma uma questão de convenção. É por isso que eu digo que este tipo de exemplos não suporta o relativismo cultural (1999, p. 173).
}

É nesse sentido que podemos falar que o realismo pragmatista (tal como doravante chamarei o realismo interno) pode resguardar a objetividade. A objetividade, nessa acepção, está condicionada às nossas limitações mais fundamentais, tais como as características fisiológicas e o modo como a nossa racionalidade pode ser constituída, e "Absolutamente nada que digamos sobre qualquer objeto o descreve como ele é 'em si', independentemente dos seus efeitos em nós" (PUTNAM, 1992, p. 90).

A objetividade descrita no realismo pragmatista é uma compreensão da condição humana no âmbito epistêmico, com a vantagem de não assumir uma posição relativista. A posição relativista é definida por Putnam da seguinte maneira: "O propósito global do relativismo, a sua própria característica definidora, é, todavia, negar a existência de qualquer 
noção inteligível de 'adequação' objetiva” (1992, p. 160). Nesse caso específico, o mérito do realismo pragmatista é fornecer uma noção de objetividade, muito embora recuse-se a aderir à proposta segundo a qual a realidade é formada por objetos em si, independentes da mente.

Conforme Putnam o compreende, quando dizemos que conhecemos alguma coisa, ou que certo aspecto da realidade é objetivo, o que se quer dizer com isso é que há uma noção de verdade que pode ser preservada, apesar de se renegar uma correspondência unívoca entre as coisas (1992, p. 92). Putnam declara o seguinte:

\begin{abstract}
Uma amostra de conhecimento (i.e., um “enunciado verdadeiro") é um enunciado que um ser racional aceitaria com base em experiência suficiente do gênero daquela que é de fato possível para seres com a nossa natureza. A "verdade" em qualquer outro sentido é-nos inacessível e é-nos inconcebível. A verdade é a melhor adequação que será possível atingir no limite (1992, p. 92).
\end{abstract}

É bastante significativo que Putnam reitere a ênfase no ponto de vista de seres como nós para estabelecer o que é o conhecimento, e que o conhecimento possível a essa perspectiva é o único que pode haver. Assim, podemos entender que a referência de Putnam a essa espécie de limite quer dizer que o conhecimento humano não é incondicionado, e conceitos como objetividade, conhecimento, e verdade, estão relacionados pela circunstância naturalmente cerceada em que se encontra o gênero humano, com respeito a qual somente pode falar sobre o mundo do seu ponto de vista, e não do ponto de vista do "Olho de Deus".

Consoante a isso, os esquemas conceituais serão o cenário onde essa melhor adequação que será possível encontra o ensejo para ser implementada e constantemente aperfeiçoada, e isso acontece de tal maneira que podemos falar, ainda, de objetividade e verdade quando acionamos o realismo pragmatista. A conclusão a que chegamos, é que o realismo pragmatista com o qual Putnam nos brinda pode impetrar o raro movimento de encetar uma crítica ao realismo da metafísica tradicional, ao mesmo tempo em que preserva uma das grandes vantagens desse, qual seja, a noção de objetividade (e verdade). Desse modo, os enunciados éticos não estariam restritos a uma classe de enunciados meramente convencionais, antes, seriam aqueles também partícipes dos esquemas conceituais, e destarte, possuiriam todas as condições necessárias para estarem garantidos no âmbito em que a objetividade tem sua alçada. 


\section{CONCLUSÃO}

No primeiro capítulo deste trabalho pudemos ver as características principais do positivismo lógico e sua relação com a ética. O positivismo lógico foi um movimento filosófico do início do século XX caracterizado pela tentativa de apresentar como o conhecimento é formado. Esse programa filosófico tem pontos assim elencados: a rejeição da metafísica; o princípio de verificação; os juízos analíticos e sintéticos; e, para os fins desse trabalho, a constatação da ausência de cognitividade dos enunciados éticos.

A metafísica é rejeitada porque, segundo os positivistas lógicos, não há um modo de enunciados metafísicos que sejam passíveis de submissão a um método de verificação. É justamente essa característica da metafísica que será entendida como uma carência pelos positivistas. $\mathrm{O}$ fato de os enunciados da metafísica não serem empíricos é uma defectibilidade que os fazem estar distantes da espécie de enunciados que possuem sentido. O princípio de verificação é a condição posta para que enunciados tenham sentido ou não. Verificam-se os dados (possivelmente) disponíveis por um determinado objeto e, a partir disso, contata-se se um enunciado, formulado sob o direcionamento do nosso aparato sensorial, é verdadeiro ou falso.

As proposições analíticas e sintéticas são as duas únicas categorias de enunciados cognitivamente relevantes, isto é, que possuem sentido. A verdade ou falsidade de uma proposição sintética está condicionada à verificação, na experiência, do que é efetivamente asseverado na frase. Já nas proposições analíticas, a verdade e a falsidade de uma proposição não são verificáveis principalmente na experiência. Essa espécie de proposição tem sua verdade ou falsidade condicionada à definição dos termos constantes no enunciado e à lógica interna estabelecida na frase.

Diante do acima exposto, não há que se considerar enunciados éticos como proposições que são valoráveis, ou melhor, não existem, nos enunciados éticos, condições para que se possa constatar sua relevância cognitiva dentro dos critérios estabelecidos pelos positivistas lógicos. Desta feita, encerra-se o capítulo com a intenção de apresentar, no capítulo subsequente, uma refutação dos princípios que amparam o positivismo lógico, tendo em vista alcançar, quando dessa refutação, a amplitude conceitual filosófica para fundamentar a posição putnamiana.

Nosso propósito, no primeiro capítulo, foi o de levantar as questões que suscitaram, por meio do positivismo lógico, a consolidação da dicotomia fato/valor, cuja problematização 
tem como ponto fulcral a noção de fato e a consequente definição do que pode ou não ser um enunciado cognitivo.

No segundo capítulo começamos por abordar a crítica que Putnam faz aos positivistas lógicos, pois dessa maneira ele pode reconstruir a noção de fato para efetivar o imbricamento dos conceitos de fato e valor reconstruídos. O capítulo é perpassado, ainda, por uma importante crítica de Putnam ao realismo tradicional, e sua consequência mais imediata é romper com a noção de uma teoria da verdade por correspondência endossada por essa espécie de realismo, uma vez que ele, Putnam, recusa uma correspondência unívoca para com a realidade, como vimos.

A partir dessas críticas, ele consegue apontar que os valores, especificamente os valores epistêmicos, podem ser objetivos, e que caso não o sejam, ocorrerá o comprometimento das asserções que estão baseadas neles. Essas asserções são enunciados factuais do âmbito científico. Depois de feita essa crítica ao positivismo lógico, ao realismo tradicional e demonstrada a objetividade dos valores epistêmicos, Putnam apresenta o modo como o imbricamento entre os enunciados factuais e avaliativos, já anteriormente apresentado, possibilita a objetividade de enunciados éticos. Putnam revela tal possibilidade com a exposição dos conceitos éticos espessos.

Essa espécie de conceito ético não está sujeita à fatoração em um componente descritivo e em um componente avaliativo. Sem a alternativa da fatoração em dois tipos de componentes separados de forma estanque, a imbricação torna-se inevitável. A objetividade insere-se, assim, no tocante à cognitividade que os enunciados éticos, dessa forma imbricados, passam a possuir. Podemos, a partir disso, considerar que enunciados éticos podem ser designados do ponto de vista do seu valor de verdade, como foi argumentado.

No terceiro capítulo apresentamos o debate entre Putnam e Habermas, que ocorre no ano de $1999^{78}$. Nossa intenção, como já foi amplamente dito, foi apresentar a posição putnamiana, e para isso tivemos que evitar nos aprofundarmos nos interessantes desenvolvimentos que Habermas empreende e que têm sido bastante estudados no meio acadêmico brasileiro.

No debate em questão, Putnam discute a dicotomia entre as normas e os valores, e nesse processo pôde utilizar argumentos que já lhe estavam à mão, como, por exemplo, os conceitos éticos espessos. Também pôde trazer à baila indicadores do desenvolvimento da

\footnotetext{
${ }^{78}$ Esse é o ano em que Putnam publica a Corda Tripla, e que Habermas publica Verdade e Justificação, dois importantes livros da maturidade intelectual desses pensadores.
} 
questão, encetando uma crítica à teoria “Apel-Peirce”, o que revela o nicho específico de suas considerações pragmatistas, a saber, o caráter deweyano que o motiva. Posteriormente, apresenta uma recusa à tendência naturalista que tem embalado os projetos éticos contemporâneos.

Depois disso, Habermas inicia sua réplica tentando dialogar com os pressupostos da posição de Putnam, apresentada na primeira parte do debate. Habermas considera que Putnam possui uma abordagem kantiana, no que concerne à demarcação epistêmica, posicionando-se, assim, contra o dogmatismo, na figura do realismo tradicional, e contra o ceticismo, na figura do empirismo. Sobre a crítica ao realismo tradicional, Habermas aventa o realismo pósmetafísico, que endossa a crítica e adere aos pressupostos que já havíamos falado no capítulo 2. Posteriormente, faz referências à objetividade e ao naturalismo, buscando uma relação putnamiana entre linguagem e mundo, o que está ligado à lembrança de Habermas sobre a relativização na perspectiva do contexto. Segue Habermas com uma abordagem à noção putnamiana de razão, enxergando nela uma importante virada pragmática, e discute a questão da objetividade dos valores do ponto de vista de Putnam para, enfim, tentar reconstruir a perspectiva desse.

A resposta de Putnam, que encerra por ora o debate, aponta para discordâncias com respeito às considerações que Habermas lhe faz. Putnam rejeita a relação entre validade dos enunciados éticos (de modo geral) e os enunciados empíricos que Habermas lhe atribui; e a noção de verdade como um termo para designar essa suposta validade.

Na linha da resposta de Putnam a Habermas, procuramos aprofundar, no quarto capítulo, os conceitos de validade e verdade de Putnam, dando ênfase ao tratamento que ele vem dando a essas questões recentemente, tendo por base sua noção de 'realismo interno', compreendido como um realismo pragmatista. O realismo pragmatista rejeita tanto o realismo da metafísica tradicional, quanto o relativismo cultural, sublinhando o papel humano na configuração do real, e configurando-se, assim, uma alternativa moderada do realismo, em que é possível desenvolver-se um arcabouço teórico capaz de garantir que haja objetividade nos contextos linguísticos que estruturam nossas inter-relações comunitárias.

Após a exposição dos pontos desenvolvidos nesse trabalho, pensamos que ainda há questões a serem deslindadas, cujo aprofundamento poderá trazer respostas a alguns problemas. Primeiramente, a problemática do pluralismo cultural. Dada a questão de tornar os valores objetivos, surge o receio de que um fato incontornável na cultura ocidental seja agredido, qual seja, a multifariedade dos modos de vida. $\mathrm{O}$ formato escolhido por diversas 
comunidades seria constrangido no caso de nos posicionarmos favoravelmente à objetividade dos valores? Colocado de outra forma: se a objetividade dos valores for uma postura aceite, estará implicado um único modo de viver, em que só poderemos estatuir uma forma moral unívoca? Se a resposta for sim, todo o argumento acerca da cognitividade dos valores provoca um resultado muito mais oneroso do que a não cognitividade. Se a resposta for uma negativa, então como poderíamos esclarecer que o pluralismo cultural não significa um "vale tudo" moral, em que a própria objetividade dos valores estaria ameaçada?

Putnam parece indicar um caminho, segundo o qual melhorar nosso discurso ético é possível. Esse melhoramento ético discursivo pode remeter à multifariedade dos modos de vida, sem que isso signifique diminuir ou diluir a pretensão de objetividade de enunciados éticos. Nesse ponto estaremos lidando diretamente com o relativismo moral (e cultural). Um interlocutor de Putnam, nesse caso, é Richard Rorty ${ }^{79}$.

A segunda questão é a da universalidade dos termos avaliativos. Como poderíamos universalizar termos avaliativos? É possível levar diversas culturas a compreender os termos que somente têm um significado em uma comunidade cultural específica distinta, e isso é passível de explicação por meio de argumentos anti-incomensuralistas e argumentos a favor da tradutibilidade. Desse modo estaríamos a concluir que a universalidade de termos éticos é cabível no tocante à compreensão.

Restará, porém, depois disso, uma importante questão residual: se podemos fazer compreender, e nós mesmos podemos compreender termos éticos, enquanto termos objetivos, como não os aceitar inexoravelmente? E aceitá-los, afinal, não nos levaria novamente ao problema de uma progressiva padronização dos valores? Deveremos explicar como que objetividade não quer dizer imutabilidade, dentro desse novo enquadramento. Para explicar as decorrências políticas acima expostas, deveremos explanar detalhadamente o que "verdade" significa para Putnam.

No presente trabalho há indicações constantes, pois ele recusa claramente uma teoria da verdade por correspondência, criticando Apel e Peirce a uma só vez, e sugerindo uma espécie de pragmática wittgensteineana. Assim, será preciso explicar profundamente o que são os elementos que Putnam toma de sua interpretação de Wittgenstein, a saber, os conceitos de aplicação e uso. Essa interpretação de Putnam com respeito a Wittgenstein é heterodoxa, tratando-se muito mais de uma apropriação de temas wittgensteineanos.

\footnotetext{
${ }^{79}$ Podemos citar, a título de exemplo, os seguintes livros de Richard Rorty: Objetivismo, Relativismo, e Verdade; Verdade e Progresso; Consequências do Pragmatismo. Há dois outros textos menores, mas muito explicativos: Para que serve a verdade; e Uma Ética Laica.
} 
Por fim, a questão do giro pragmático de Putnam, uma vez que ele está, em toda a sua argumentação, fortemente inspirado pelo pragmatismo norte-americano, principalmente por John Dewey, embora rejeite a posição "apel-peirceana”, também pragmática, como vimos. Devemos fazer a exegese dessa influência e apontar as decorrências fundamentais dela. Isso explicará a espécie de aproximação do pragmatismo e da interpretação que Putnam empreende com relação a Wittgenstein.

Diante de todo o exposto, o autor deste trabalho pensa que será necessário e relevante continuar o desenvolvimento do tema, que é bastante complexo, e do qual decorrem as questões supracitadas. Isso requererá uma pesquisa futura. 


\section{BIBLIOGRAFIA}

APEL, Karl-Otto. Transformação da filosofia II. São Paulo: Edições Loyola, 2000.

AYER, Alfred Jules. Lenguaje, Verdad y Lógica. Barcelona: Ediciones Martínes Roca, 1971.

BLACKBURN, Simon. Dicionário Oxford de filosofia. Rio de Janeiro: Zahar, 1997.

BERNSTEIN, Richard J. The Pragmatic Turn. Cambridge: Polity Press, 2010.

BOGHOSSIAN, Paul. Medo do conhecimento: contra o relativismo e o construtivismo. São Paulo: Editora Senac, 2012.

BRANQUINHO, João \& MURCHO, Desidério \& GONÇALVES GOMES, Nelson (Ed). Enciclopédia de Termos Lógico-Filosóficos. São Paulo, SP: Martins Fontes, 2006.

CARNAP, Rudolf. Der Logische Aufbau der Welt. Hamburg: Felix Meiner Verlag, 1961.

Press, 1950 . Logical Foundations of Probability. Chicago: The Chicago University

. Testability and Meaning. In: Philosophy of Science, vol. 3, pp. 420-471; vol.4, pp. 1- 40, 1936-7. (Tradução brasileira em versão compactada: Testabilidade e Significado. In: Pensadores, pp. 171- 219. Tradução: Luiz João Baraúna \& Ruben Pablo Mariconda. São Paulo: Abril Cultural, 1988).

Pseudoproblemas na Filosofia. In: Pensadores, pp. 143-169. Tradução:

Luiz João Baraúna \& Ruben Pablo Mariconda. São Paulo: Abril Cultural, 1988.

DE OLIVEIRA, Manfredo A. Reviravolta linguístico-pragmática na filosofia contemporânea. $3^{\mathrm{a}}$ ed. Ipiranga, SP: Edições Loyola, 2006.

DEWEY, John. Reconstrução Em Filosofia. Editora: ícone, 2012.

. A valoração das ciências humanas. Ed.: Autores Associados, 2009.

Teoria da Vida Moral. In: Os Pensadores. São Paulo: Abril Cultural, 1980.

GUIDO, Imaguire \& SCHIRN, Matthias. Estudos em filosofia da linguagem. São Paulo: Edição Loyola, 2008.

HABERMAS, Jürgen. Teoria do agir comunicativo. São Paulo: Editora WMF Martins Fontes, 2012.

Brasileiro, 1989. Consciência Moral e Agir Comunicativo. Rio de Janeiro: Tempo Verdade e Justificação. São Paul, SP: Edição Loyola, 2004.

HARRIS, Sam. A paisagem moral: como a ciência pode determinar valores humanos. São Paulo, SP: Companhia das Letras, 2013.

HUME, David. Tratado da natureza humana. São Paulo: Editora UNESP, 2009.

JAMES, William. Pragmatismo e textos selecionados. In: Os Pensadores. São Paulo: Abril Cultural, 1974.

KANT, Immanuel. Crítica da razão pura. Petrópoles: São Francisco, RJ: Vozes, Bragança Paulista, SP: Editora Universitária São Francisco, 2012. Fundamentação da metafísica dos costumes. Barcarolla, 2010. 
KORSGAARD, Christine. The sources of normativity. Cambrigde: Cambridge University Press, 1996.

. Motivation, Metaphysics, and the value of the self: a reply to Ginsborg Guyer, and Schneewind. Ethics, 109, p. 49-66, outubro de1998.

KUHN, Thomas. A estrutura das revoluções científicas. 12a ed. São Paulo: Perspectiva, 2013.

NAGEL, Thomas. Visão a partir de lugar nenhum. São Paulo, SP: Ed. Martins Fontes, 2004.

NAVIA, Ricardo. En Torno a la Polémica Habermas-Putnam sobre la Validez Racional de los Juicios Éticos y Morales. In: Dissertatio. Vol.: 35, pp. 11-30, 2012.

EDIPUCRS, 1999.

Verdade, Racionalidade e Relativismo em H. Putnam. Porto Alegre, RS:

MOODY-ADAMS, Michele. Fieldwork in familiar places: morality, culture and Philosophy. Cambridge, Mass: Havard University Press, 1997.

MURDOCH, Iris. Sartre, romantic rationalist. New Haven: Yale University Press,1953.

. The sovereignty of good. New York: Schocken, 1971. (A Soberania do Bem. $1^{\circ}$ ed - São Paulo: Editora Unesp, 2013).

PUTNAM, Hilary. O colapso da verdade e outros ensaios. Aparecida, SP: Ideias \& Letras, 2008a.

$2008 c$.

Corda tripla: mente, corpo e mundo. Aparecida, SP: Ideias \& Letras, Las mil caras del realismo. Barcelona: Ediciones Paidós Ibérica, S.A., 1994.

Representación y Realidad: Un balance crítico del funcionalismo. Barcelona: Editorial Gedisa S. A., 2014.

. Realismo de rosto humano. Lisboa: ed. Instituto Piaget, 1999a.

. Renovar a filosofia. Lisboa: ed. Instituto Piaget, 1999b

. Razão, verdade e história. Lisboa: Publicações Dom Quixote, 1992.

. Ethics without ontology. Cambridge, Mass.: Harvard Press, 2004.

. Word and Life. Cambridge, Mass.: Harvard Press, 1995.

. The analytic and the synthetic. In: Mind, Language and Reality, Philosophical

Paper, Vol. 2. Cambridge: Cambridge University Press, 1975.

'Two dogmas' revisited In: Realism and Reason, Philosophical Paper, Vol. 3. Cambridge: Cambridge University Press, 1983.

Why Reason can't be naturalized. In: Realism and Reason. , Philosophical Paper, Vol. 3. Cambridge: Cambridge University Press, 1983.

. The meaning of meaning. In: Language, Mind, and Knowledge. Minnesota Studies in The Philosophy of Science, vol. VII, pp. 131-193. Minnesota: ed.University of Minnesota Press, 1975.

PUTNAM, Hilary \& HABERMAS, Jürgen. Normas y valores. Introducción, traducción y notas de Jesús Vega Encabo y Javier Gil Martín Madrid: Editorial Trotta, 2008b. 
RACHELS, James \& RACHELS, Stuart. Elementos da filosofia moral. $7^{a}$ edição. Porto Alegre: AMGH, 2013.

RAND, Ayn. The Virtue of Selfishness: A New Concept of Egoism. New York: Signet Book, 1964.

RORTY, Richard. Objetivismo, Relativismo, e Verdade. Rio de Janeiro, RJ: Relume-Dumará, 1997. . Verdade e Progresso. Barueri, SP: Manole, 2005. . Consequências do Pragmatismo. Lisboa, PT. Instituto Piaget, 1999. . Uma Ética Laica. São Paulo: WMF Martins Fontes, 2010.

RORTY, Richard \& ENGEL, Pascal. Para que serve a verdade? São Paulo: Editora UNESP, 2008.

STEGMÜLlER, Wolfgang. Filosofia Contemporânea: Introdução Crítica. $2^{\mathrm{a}}$ ed. - Rio de Janeiro, RJ: Forense Universitária, 2012.

VAN QUINE, Willard. Epistemologia naturalizada. In: Os Pensadores, pp. 157-169. São Paulo: Abril Cultural, 1980.

72. São Paulo: Unesp, 2011.

Dois dogmas do empirismo. In: De um ponto de vista lógico pp. 37-

Carnap and Logical Truth. In: SCHILPP, P. A. (ed). From a logical point of view. Ed. Cambrigde, Mass.: Havard University Press, 1961.

VEGA ENCABO, J. \& GIL MARTÍN, J., "Introducción: Pragmatismo, objetividad normativa y pluralismo".In: PUTNAM, H. \& HABERMAS, J. Normas y valores. Madrid: Ed. Trotta, 2008.

WEINBERG, Julius Rudolph. Examen del Positivismo Logico. Madrid: Aguilar, 1959.

WILLIAMS, Bernard. Ethics and the limits of Philosophy. Milton Park, Abingdon: Routledge, 2006.

WITTGENSTEIN, Ludwig. Investigações Filosóficas. 6ª ed. - Petrópoles, RJ: Vozes, 2009.

. Tractatus Logico-Philosophicus. $3^{\mathrm{a}}$ ed. - São Paulo, SP: Editora da Universidade de São Paulo, 2010.

WITTGENSTEIN, Ludwig \& WAISMANN, Friedrich. Wittgenstein and the Vienna Circle: conversations record by Friedrich Waismann. Oxford, England: Basil Blackwell, 1979. 